SECRT

PWAC - 139

THIS DOCWMET CONSISTS OF 126 PACES

No. 8 . 8 . 40 SERIES $C$

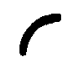

HAZARDS SUMMARY REPORT

ON

NUCLEAR PHYSICS LABORATORY

AT

CANEL

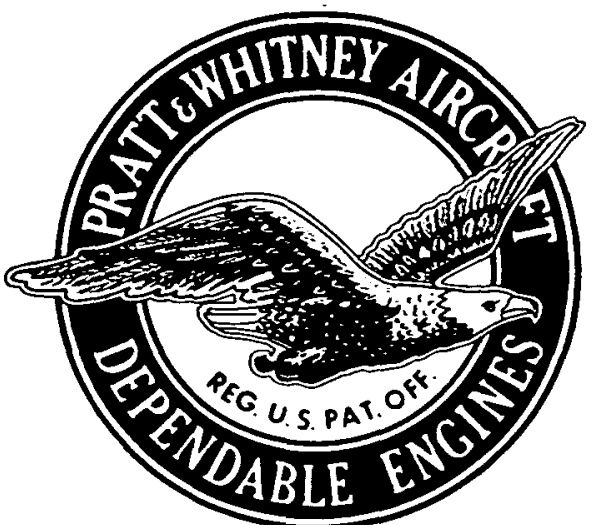

Facsimile Prices 9.60 Microfilm Price $\$ 3.68$

Available from the

Office of Technical Services

Deportment of Commerce

Washington 25, D. C.

Chasification cancelled (or elanged to OMISSIFIE

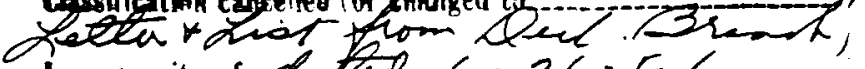
by sut rit! of Lated 6-26-6al

b. Tie, date $7-12 \cdot 61$

\title{
RESTRIED DATA
}

This document contains rethidad data as defined in the This document ts Atomic Energy Act of 1940 transmittal or the dis-

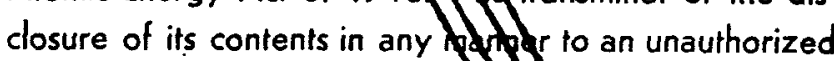
person is prontifed.

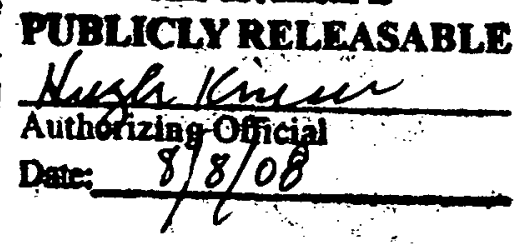

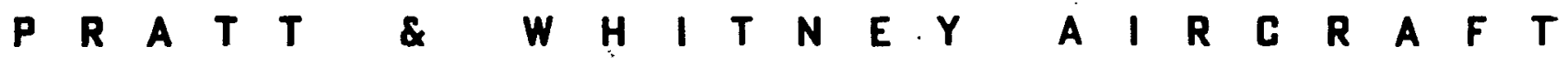
DIVISIDN DF UNITEDA IRCRAFT CORPORATION E A S T H A R T F O R D 


\section{DISCLAIMER}

This report was prepared as an account of work sponsored by an agency of the United States Government. Neither the United States Government nor any agency Thereof, nor any of their employees, makes any warranty, express or implied, or assumes any legal liability or responsibility for the accuracy, completeness, or usefulness of any information, apparatus, product, or process disclosed, or represents that its use would not infringe privately owned rights. Reference herein to any specific commercial product, process, or service by trade name, trademark, manufacturer, or otherwise does not necessarily constitute or imply its endorsement, recommendation, or favoring by the United States Government or any agency thereof. The views and opinions of authors expressed herein do not necessarily state or reflect those of the United States Government or any agency thereof. 


\section{DISCLAIMER}

Portions of this document may be illegible in electronic image products. Images are produced from the best available original document. 
Page No.

List of Figures

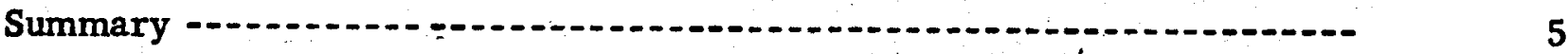

Introduction - 9

I. The Facility and Its Operation 13

A. Location - 15

B. Building -

1. Test Cells -

2. Control Rooms -

3. Storage-Assembly Vaults

4. Counting Room - 19

5. Instrument Room -

6. Other Labs, Shops, and Offices -........ 19

7. Electric Power

8. Waste Disposal -

9. Building Safety Features and Alarms $\ldots$

C. Anticipated Reactor Assemblies - 22

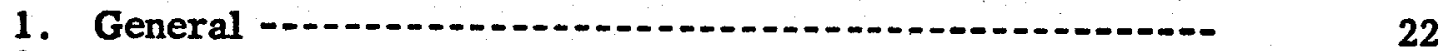

2. Room Temperature Assemblies -.......................-. 22

a. Reactor -

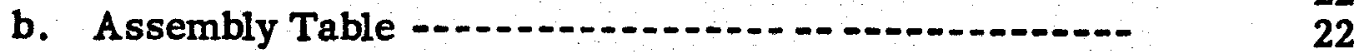

c. Safety Rod Mechanisms -

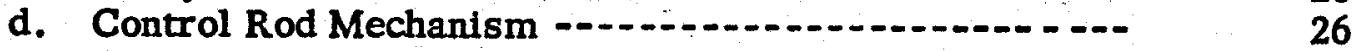

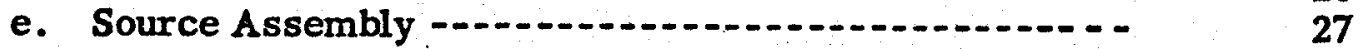

3. Elevated Temperature Assembly -..................... 27

a. General -......... 27

b. Fuel Handling System -.....

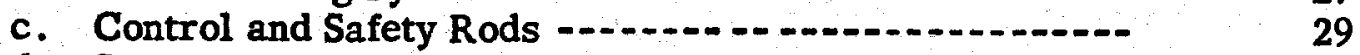

d. Source -29

D. Instrumentation and Controls

1. General -_. 30

2. Operational and Control Instrumentation -..-...........-. 30

3. Safety Circuits -

E. Plan of Normal Operation

1. Handling of Fissionable Material _............ 33

2. General Operation of a Critical Assembly -............ 33

3. Initial Approach to Criticality 
Page No.

F. Types of Experiments $\quad 35$

1. Room Temperature Experiments 35

a. Determination of Critical Mass - 35

b. Rod Calibrations - 35

c. Flux and Power Distributions - 35

d. Reactivity Coefficients

e. Temperature Coefficient - 35

f. Other Experiments - 35

2. Elevated Temperature Experiments

a. Determination of Critical Mass - 36

b. Rod Calibration - 36

c. Flux and Power Distribution - 36

d. Reactivity Coefficients

e. Temperature Coefficients

f. Other Experiments - 36

G. Safety Mechanisms 37

1. Intrinsic Safety Features

2. Scram System

3. Mechanisms to Prevent Unsafe Operations - 38

II. Hazards and Accidents 41

A. Potential Hazards and Countermeasures

1. Action by Personnel

2. Malfunction of Equipment 45

3. Possible Autocatalytic Characteristics

4. Flood, Fire, and Earthquake 45

B. Information Used In Evaluating Hazards 47

C. Damage and Radioactivity Release in Case of Failure

1. General - 48

2. Room Temperature Assembly Accidents

a. Gradual Removal of an Experimental Control Rod

Worth $4 \%$ from an Already Critical Assembly

b. Instantaneous Introduction of $4 \%$ Excess Reactivity into a Reactor Already Critical with all Interlocks and

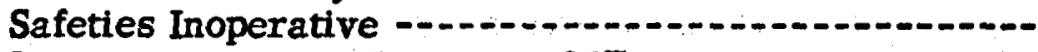

c. Instantaneous Introduction of $25 \%$ Excess Reactivity with Safeties Inoperative -

3. Elevated Temperature Assembly Accidents

a. Gradual Removal of an Experimental Control Rod Worth 4\% from an Already Critical Assembly -

b. Instantaneous Introduction of $4 \%$ Excess Reactivity in an Already Critical Assembly

4. Damage to the Building 
III. Hazards to Surrounding Area

Page No.

A. Fission Product Release

B. Irradiation by Radioactive Cloud

C. Contamination Due to Rainout

D. Contamination Due to Dry Fall-Out

IV. Make-Up of Surrounding Area 65

A. Population Distribution 67

B. Vital Installations Near Site 70

C. Railroad, River, and Automoblle Traffic

D. Meteorology

E. Geology and Hydrology

F. Selsmology -

V. Appendices

A. Analysis of Accidents 79

B. Calculation of Effects on Surrounding Area

C. Industries Adjacent to Site

D. Meteorology

E. Geology and Hydrology

63 


\section{LIST OF FIGURES}

Figure No.

Page No.

Nuclear Physics Laboratory - Second Floor Plan and South

Elevation-

Typical Room Temperature Critical Assembly I -

Block Diagram of Instrumentation

Effect of Continuous Rod Removal on Power, Energy and

Period -........

9 Linear Expansion of "Teflon" Total Length vs Temperature- 


\section{SUMMARY}

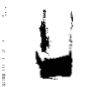

4

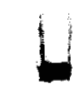

$\Delta$

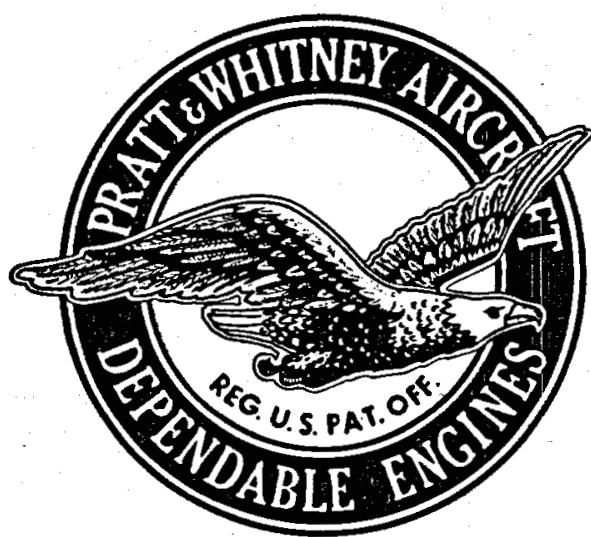

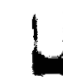

1
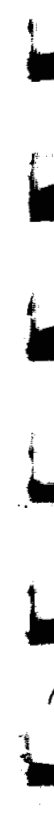
5

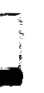

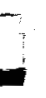

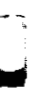

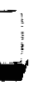

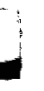

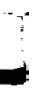

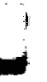

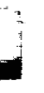

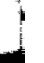

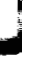

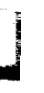

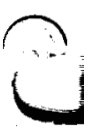

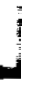


P.WAC - 139

SUMMARY

The critical experiment facility to be built at CANEL for operation by Pratt \& Whitney Aircraft is described for consideration and approval by the Advisory Committee on Reactor Safeguards. Since the nature of the experimental assemblies and operations is important in this consideration, this information is also included where available for the anticipated initial experiments, which may be regarded as typical. Safety features of the building, equipment, and operations are pointed out. Possible accidents and the resulting hazards to surrounding areas are analyzed. The make-up of the surrounding area is described with supporting reports as appendices.

The facility will be near the Connecticut River below Middletown, Connecticut, 1000 feet from the nearest laboratory installation and over balf a mile from the nearest residence. The building will have two test cells with associated control rooms, vaults, laboratories, shop, and office area. For shielding, the test cells will have 5 to 6 foot thick concrete walls and 3 foot ceiling. Ventilation equipment will provide proper conditions for instruments and materials, maintain flow from clean to possibly contaminated areas, and isolate each cell and vault. Electric power will be furnished from a dual supply system, with dual lines, plus a small local emergency unit. Water lines will be excluded from the cells and vaults. Hold-up tanks will be provided for drains possibly carrying valuable or radioactive material. Other drainage will be into the storm or sanitary sewage system. Normal air exhaust will be passed through Chemical Warfare Service filters where desirable. Lights and alarms will be distributed in and around the building to warn of fire and muclear hazards. Communication systems will be adequate for keeping personnel informed during emergencies.

Initial experiments are expected to be mock-ups of circulating-fuel reflector-moderated reactors both at room and elevated temperatures. The room temperature experiment will use pieces loaded on a split table and brought together under carefully controlled conditions to achieve criticality. Speeds of table closure and control rod motion will be limited to give safe rates of reactivity increase. Interlocks will aid in following the proper sequence of operations. Instruments will keep operators informed of neutron density levels and changes at all times. In case these become excessive, a scram system triggered automatically or manually will insert safety rods and separate the table halves. The elevated temperature experiments will use molten fuel which can be injected into or drained from the fuel region of a heated assembly of fixed geometry. A single poison rod will serve both control and safety functions. Interlocks and safety systems will follow the same philosophy as for room temperature experiments.

Fissionahle material not in use will be stored in vaults operated as accountability substations. Vaults and test cells will be adequately secured and alarmed.

Operating procecures call for safety review of plans, proper number and type of personnel to operate, daily checks on instruments and safeties, and keeping of adequate records. During initial approach to criticality with a new or significantly rearranged assembly, source multiplications will be measured as the fuel is added in small increments.

Experiments on both types of assemblies will include determination of critical mass, rod characteristics, flux and power distributions, reactivity coefficients of materials, and temperature coefficients.

Hazardous situations could occur as a result of either inadvertent or sabotage actions by personnel, malfunction of equipment, autocatalytic characteristics, or catastrophes such as fire, flood or earthquake. These are counteracted by selecting personnel, establishing 
and emphasizing safe procedures, having a strong security system,providing interlocks and scram systems, using high quality equipment designed to fail safe, checking equipment frequently, minimizing use of flammable materials, and having adequate natural drainage.

Accidents selected for analysis are those resulting from either gradual or instantaneous introduction of 4 to $25 \%$ excess reactivity with safeties inoperative. The mechanism of shutdown would be self disassembly caused by pressure of vaporized fuel. Pessimistic results based upon simplified methods indicate a maximum burst of about $10^{19}$ fissions and a release of $7 \times 10^{18}$ fission nuclel to the atmosphere. The test cells will become contaminated but will withstand the anticipated surge of pressure and temperature.

Conservatively calculated doses indicate that the general public will be exposed to considerably less than LD 50 amounts under the worst conditions.

The nearest large community is Middletown which has a population of 20,000 and is 5 miles to the northwest. The nearest vital installation is a steam-electric generating station 1 mile northwest. Winds are generally from the north in winter and from the south in summer with speed averaging between 4 and $12 \mathrm{miles} / \mathrm{hr}$. Local drainage will be into the river. Probability of earthquakes is slight. 


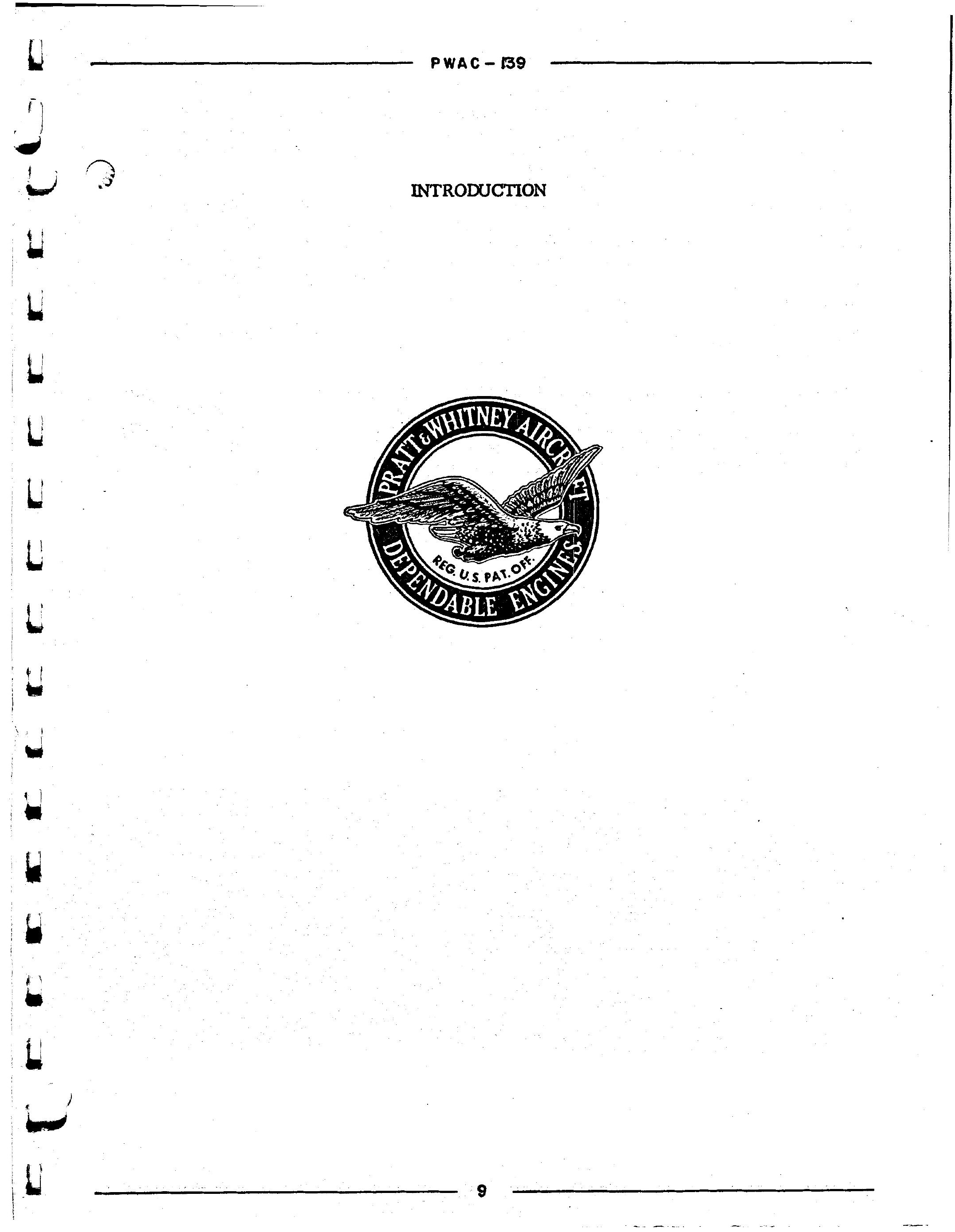




\section{INTRODUCTION}

As part of the effort by Pratt \& Whitney Aircraft to develop a nuclear powerplant for aircraft, critical experiments will be conducted. For this purpose a nuclear physics laboratory is to be built as part of the Connecticut Aircraft Nuclear Engine Laboratories (CANEL). Information on desirable features for the building and equipment has been obtained by working for several years at some of the existing laboratories and by visiting at most of the others of this type.

This report has been prepared at the present time in order to obtain approval of the facility by the Advisory Committee on Reactor Safeguards before construction starts. Many details of the experimental assemblies and operations are not available yet but where omitted should not be vital to the evaluation of the basic features of the facility, especially since the facility may well need to accommodate a variety of types of experimental assemblies in the future. As the details of any one assembly become available, a separate report will be submitted to the Committee for approval. 


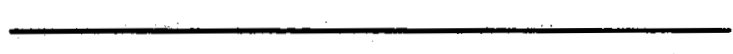

4 
4

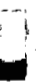

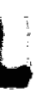

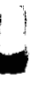

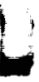

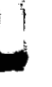

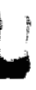

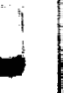

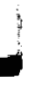

1

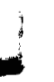

1 


\section{A. LOCATION}

The building will be located in the northern half of the Connecticut Aircraft Nuclear Engine Laboratory (CANEL) site on the Connecticut River below Middletown, Connecticut. The nearest population on the site will be outside an exclusion fence which has a radius of approximately 1000 feet. The nearest residence will be about 3000 feet away. This is an area of wooded hills sloping to the river with gullies formed by small streams carrying surface drainage. The maximum flood height of the river is about 27 feet, which is far below the 140 foot elevation of the building floor. Local flooding of the building will be prevented by the fact that it will be built on a projection from benchland and is surrounded by steep slopes downward on three sides.

Further information on the surrounding area will be given in a later section of this report. 


\section{B. BUILDING}

The floor plans and elevations for the Nuclear Physics Laboratory building are shown in Figs 1 and 2. The building will consist of two high-bay test cells with associated assemblystorage vaults in between, control rooms adjacent on two levels, and an adjoining section containing a counting room, laboratories, locker rooms, offices, etc. on the ground floor. Services, consisting mostly of ventilating equipment, will be contained in two rooms, one over the assembly-storage vaults and one over the laboratory area. The cells, vaults and counting rooms will be of concrete construction. The remainder will have steel panel siding and either steel panel or concrete partitions. The whole building will have concrete slab floors. Additional finish materials will be provided where desirable.

1. Test Cells

Each test cell will be 41 feet long, 40 feet wide and 40 feet high, giving a total inclosed volume of $65,600 \mathrm{cu} \mathrm{ft}$.

The shielding walls and ceiling of the cells will be made of reinforced ordinary concrete. The wall on the control room side will be 6 feet thick and the other three walls 5 feet thick. The walls will be full thickness all the way up except for a 2-foot jog near the top where there will be crane rails. The ceiling will be 3 feet thick.

In the wall opposite the control rooms each cell will have at ground level a personnel door (about 3.5 by 7 feet) and a truck door (about 10 by 12 feet). A second personnel door will be provided on the upper level over the storage vault. These doors will have shielding values approximately the same as the wall.

The personnel doors will be constructed so that they can be opened manually in case of power failure. Locks and alarms will be provided consistent with safety and security regulations as described later.

Each cell will have a separate ventilation system (located in the service area) designed to maintain constant temperature and to limit relative humidity to $45 \%$. Fresh air will be drawn in through dust filters, conditioned, and delivered to the cell through one or more labyrinth ducts over one wall. Air returning for recirculation will pass through Chemical Warfare Service filters and through similar ducts. A fraction of the air will be exhausted through the ceiling by means of a blower which can be set to maintain a slight negative pressure in the cell. Quick-closing dampers will be provided in the ducts between the cell and ventilation equipment and will be closed upon power failure, scram or pressure surge. At the same time the air circulating blowers will turn off. A damper ahead of the exhaust blower in the ceiling will be designed to close upon power failure or scram but will open to relieve pressure. An additional pressure-relief damper will allow air to bypass the blower. A short stack on the roof will direct exhaust air upward. Seals will be provided around doors and other openings to reduce leakage.

Passages for conduits between the test cells and the adjoining rooms will be provided in the form of ten 4-inch off-set pipes to each vault and to each control room near the ceilings and two $9 \times 18$-inch floor trenches going under the wall into each lower control room. When not in use, pipes will be plugged and sealed. Leakage through the trenches could be controlled by using bulkheads or by filling with a solid material such as paraffin. 
PWAC - 139

FIG I

\section{NUCLEAR PHYSICS LABORATORY}

FIRST FLOOR PLAN

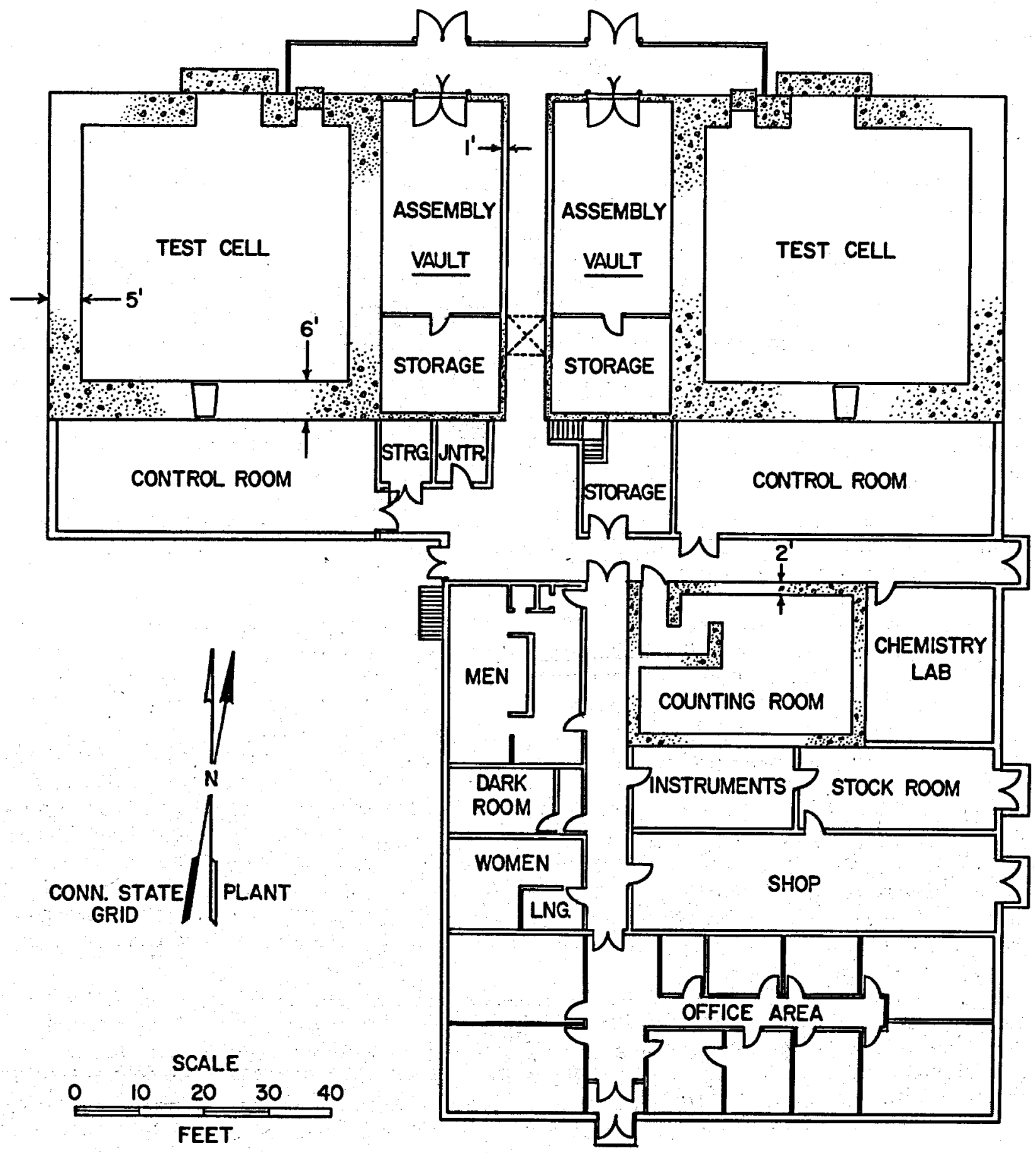


PWAC - 139

FIG 2

NUCLEAR PHYSICS LABORATORY

SECOND FLOOR PLAN

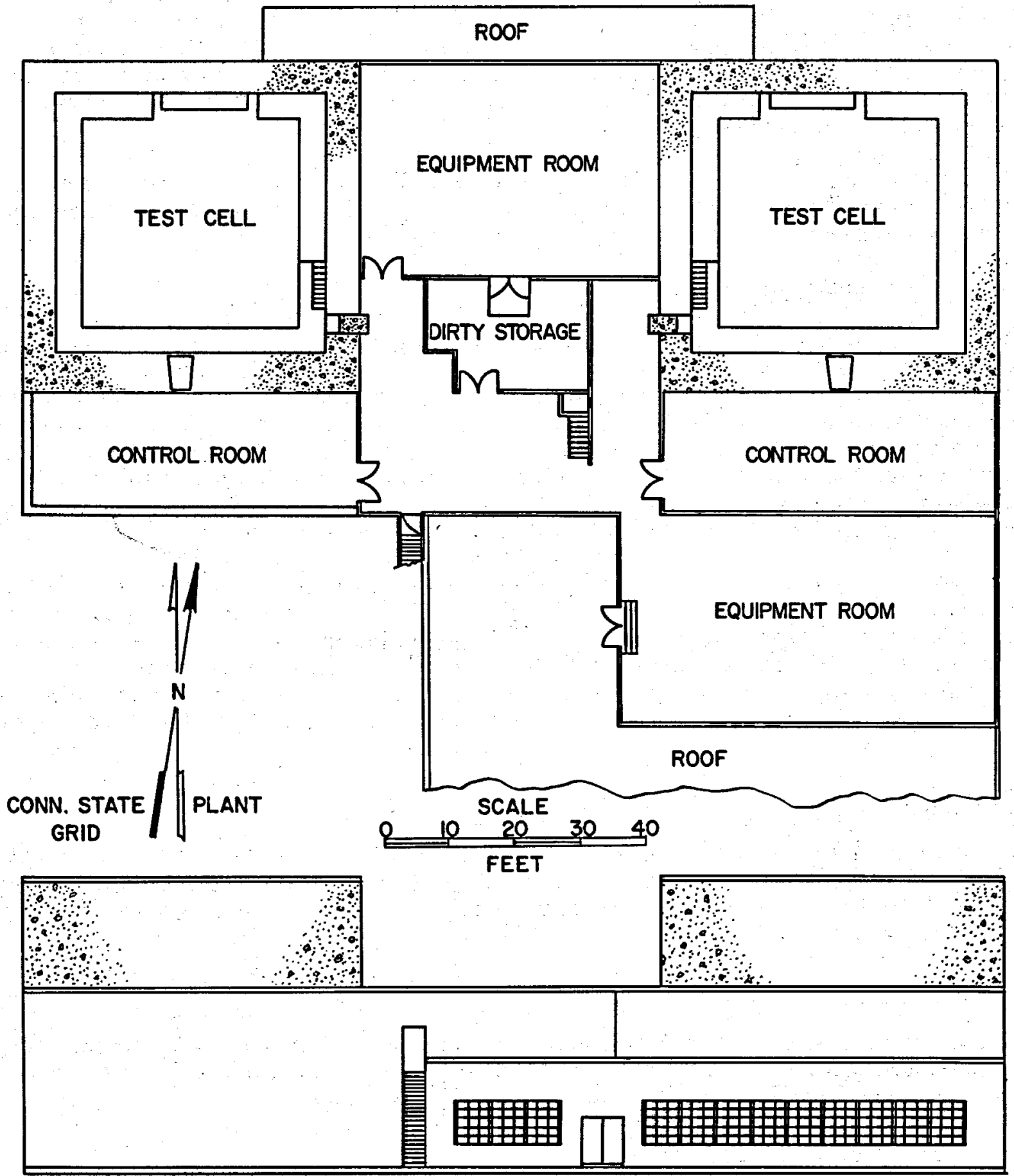

SOUTH ELEVATION 
Each cell will be provided with an overhead traveling crane. Incandescent lighting will be used. Electrical and compressed air outlets will be furnished. No water supply line or drain will be present in the cells. The concrete floor will be covered with wide strips of Vinyl material.

2. Control Rooms

Each control room is 18 by 50 feet. Control equipment will be located and operated from either lower or upper levels or possibly both depending upon the nature of the test set-ups in the cells. Constant temperature and a limit of $45 \%$ relative humidity will be maintained in the control rooms. Consoles for primary operating and recording equipment will be set up in the center of the room. Auxiliary equipment including connection panels, relay cabinets and the like will be to one side or along the walls but where readily accessible for servicing. Trenches from the cells extend across and around the room to accommodate wires and other conduits.

Direct viewing of the test assemblies will be provided by means of a zinc-bromide window in each control room. The windows will be large enough to provide a horizontal viewing angle of 120 degrees.

3. Storage-Assembly Vaults

Each storage-assembly vault will be 19 feet wide by 50 feet long with one 5 -foot thick wall common with a test cell. Consistent with Atomic Energy Commission security regulations the other walls, floor, and ceiling are 1 foot thick, the'doors are vault type, and man-proof grills will be installed in any other openings over 96 square inches in cross-section. Each vault will have a separate ventilation system providing constant temperature and limited humidity. Intake air will pass through a dust filter and the discharge air through a Chemical Warfare Service filter. The floors will be covered with wide-strip Vinyl material. No water pipes or drains will be present.

Each vault will be divided into two sections by a metal partition. In the assembly section will be work tables, storage bins and carts, and material-handling equipment for preassembly and subassembly work. Exhaust hoods or boxes may be installed if dry boxes are not adequate when handling contaminated materials. In the storage section, racks or tanks will be provided to limit the amount and control the distribution of stored fissionable material according to established practice for assuring non-critical condition even if flooded.

\section{Counting Room}

The counting room is 22 by 33 feet with labyrinth entrance and 2 foot thick walls and ceiling of ordinary concrete for shielding. Constant temperature and limited humidity of $45 \%$ will be maintained. Incandescent lights will be used. A well-grounded bus bar will be included.

\section{Instrument Room}

The instrument room for work on instruments and control devices will also have constant temperature and limited humidity. It will be provided with electrical but not radiation shielding.

6. Other Labs, Shops and Offices

The remainder of the first floor space includes a small darkroom, chemistry laboratory, stock room, shop, locker rooms, and offices. 


\section{Electric Power}

Electric power will be availablè to the building via two separate lines entering the building from different directions. Operation will normally be on purchased power and CANEL generated power simultaneously. In the event of purchased power failure, generated power will continue to be supplied by the CANEL power plant and routed through either or both lines. It is considered highly unlikely that both power lines will be inoperative simultaneously. Either floating batteries or a small diesel generator will be available locally for such contingencies to operate emergency equipment and some gamma monitors. Individual battery-powered lights will automatically illuminate all windowless areas in case of power failure.

\section{Waste Disposal}

Under normal operating conditions the amount of contaminated waste from the building will be very small. Routine checks will be made and a number of features included to take care of unusual conditions.

/ Most of any airborne contamination would originate in the test cells. As explained above 7 the normal exhaust passes through a Chemical Warfare Service filter which will remove almost all particulate matter. The mechanism of relieving pressure surge hhd also been]described 2 and the amount of radioactivity and the resulting hazards associated with such a pressure surge will be covered in later sections of the report.7

$\mathrm{r} /$ Small amounts of airborne contamination may originate from the vaults or chemistry

laboratory. These rooms have individual exhausts with Chemical Warfare Service filters.

No liquid wastes are expected other than minor amounts of material unintentionally washed down drains. Drains for which the likelihood of this is the greatest, such as those for emergency showers, janitor's sink, chemistry laboratory and lavoratories near the test cells, will be connected to holding tanks which will be monitored before being emptied. This system serves a second purpose of recovering valuable materials. Water from the roof and ground around the building will probably flow into a storm drain system emptying into the river. Remaining drains will be connected to the CANEL sanitary sewage system $\% / 2$ exd?

9. Building Safety Features and Alarms

The ventilation system in the building is designed not only to provide controlled temperature and humidity and/or flow isolation of some of the rooms as described above but also to maintain a general pattern of air flow from clean areas toward areas more likely to become contaminated. This will be accomplished by having forced ventilation with appropriate adjustable dampers and louvers in ducts and doors, plus doors at each end of the corridor running back from the office area, to assist in establishing and maintaining a pressure gradient.

As noted above, scram in a test cell will shut down the corresponding ventilation system. An electrical panel will be provided at one or two key locations whereby the ventilation systems in the rest of the building can be shut down promptly if necessary.

In both floors in the corridors between the control rooms, hand and eye-washing facilities and an emergency shower are provided.

Fire alarm boxes and bells will be distributed throughout the building and will connect with the central CANEL system. Fire detecting devices will be installed where practi- 
cal in the test cells, vaults, and control rooms. Met-L-X extinguishers will be placed in the cells and vaults, and appropriate types in other areas. There will be a fire escape from the central corridor on the second level.

Lighted signs to show when test reactors are operating will be placed in the office area, control rooms, central and rear corridors, on outside corners and at entrance roads. The scram of an assembly will cause the corresponding lights to flash and warning horns in and around the building to sound.

The building intercom system will include a few key stations located in the control rooms and perhaps elsewhere from which announcements during an emergency can be made to all other stations including speakers in the areas not covered by individual boxes.

Another set of speakers in the building will be connected to the CANEL central paging system which can be used by the central emergency headquarters for announcements regarding air raids, accidents in other buildings, etc. 


\section{ANTICIPATED REACTOR ASSEMBLIES}

\section{General}

Initial critical experiments in this facility are expected to be mockups of circulatingfuel reflector-moderated reactors both at room and elevated temperatures. The room temperature experiment will use an assembly of solid pieces or canned liquids or powders stacked on a split table allowing separation of halves during loading operations. Elevated temperature experiments will use molten fuel which can be infected into or drained from the fuel region of an assembly of fixed geometry probably inclosed in a heated tank. Present concepts of these assemblies are given below with as much detail as is available at the present time. The remaining and final design features will be kept consistent with safe practice and will be described in later reports.

\section{Room Temperature Assemblies}

\section{a. Reactor}

Two examples of likely room temperature critical assemblies are shown in Figs 3 and 4. These assemblies will consist basically of three concentric regions: a central beryllium island, a fuel region containing fissionable material and simulated carrier, and a beryllium reflector. As the figures indicate, the regions will have various shapes and will be composed of stacked solid pieces with shells of structural material such as Inconel between the regions. The radial thicknesses of the regions at the midplane will be on the order of 6 inches for the island, 7 inches for fuel region and 12 inches for the reflector. The Inconel shells will range up to about $1 / 4$ inch in thickness. Molten fluoride salt fuel will be simulated by alternate laminations of enriched uranium and Teflon at room temperature. The uranium laminations will be metallic sheets probably about 4 mils thick and the Teflon laminations will be stacks of sheets about 1/16 inch thick. Some extraneous structure will be required to support and tie together the pieces of the assembly. This will probably be aluminum in the form of horizontally stacked square tubes in the lower section and horizontal tie-rods plus a few vertical sheets in the upper section. A steel framework outside and somewhat removed from the assembly will be used as a restraint for the aluminum tubing and support for safety and control rod mechanisms. Thin aluminum face plates at the plane of table separation will hold the fuel in place.

There will be at least two control rods having a total reactivity value in excess of two dollars. There will be four safety rods worth at least one dollar apiece and totaling more than the control rods. The rods will probably be of the absorption type located in the reflector along side the fuel region. The absorbing material might be boron in the form of boral sheets mounted in aluminum sleeves.

\section{b. Assembly Table}

The assembly table that will be used to support the reactor will be constructed in two halves. One half will be fastened to the floor of the test cell and the other mounted on tracks. The maximum separation will be about five feet. The movable half will be driven by a lead screw connected through a slip clutch and gears to one of three constant-speed gear-head motors (See Fig 5). Each motor has a magnetic clutch wired so that only one motor can be connected to the lead screw at one time. Each motor has a different gear-ratio and drives the movable half of 


\section{TYPICA}

\begin{tabular}{c|c|c}
\hline ITEM & QTY & NAME \\
\hline 1 & 4 & ALUMINUM SHEET \\
2 & 4 & ALUMINUM SHEET \\
3 & 4 & ALUMINUM SHEET \\
5 & 2 & ALUMINUM SHEET \\
6 & 2 & ALUMINUM SHEET \\
7 & 2 & ALUMINUM SHEET \\
8 & 2 & ALUMINUM SHEET \\
9 & 2 & ALUMINUM SHEET
\end{tabular}

\section{ROOM}

\section{TEMPERATURE CRITICAL ASSEMBLY I}

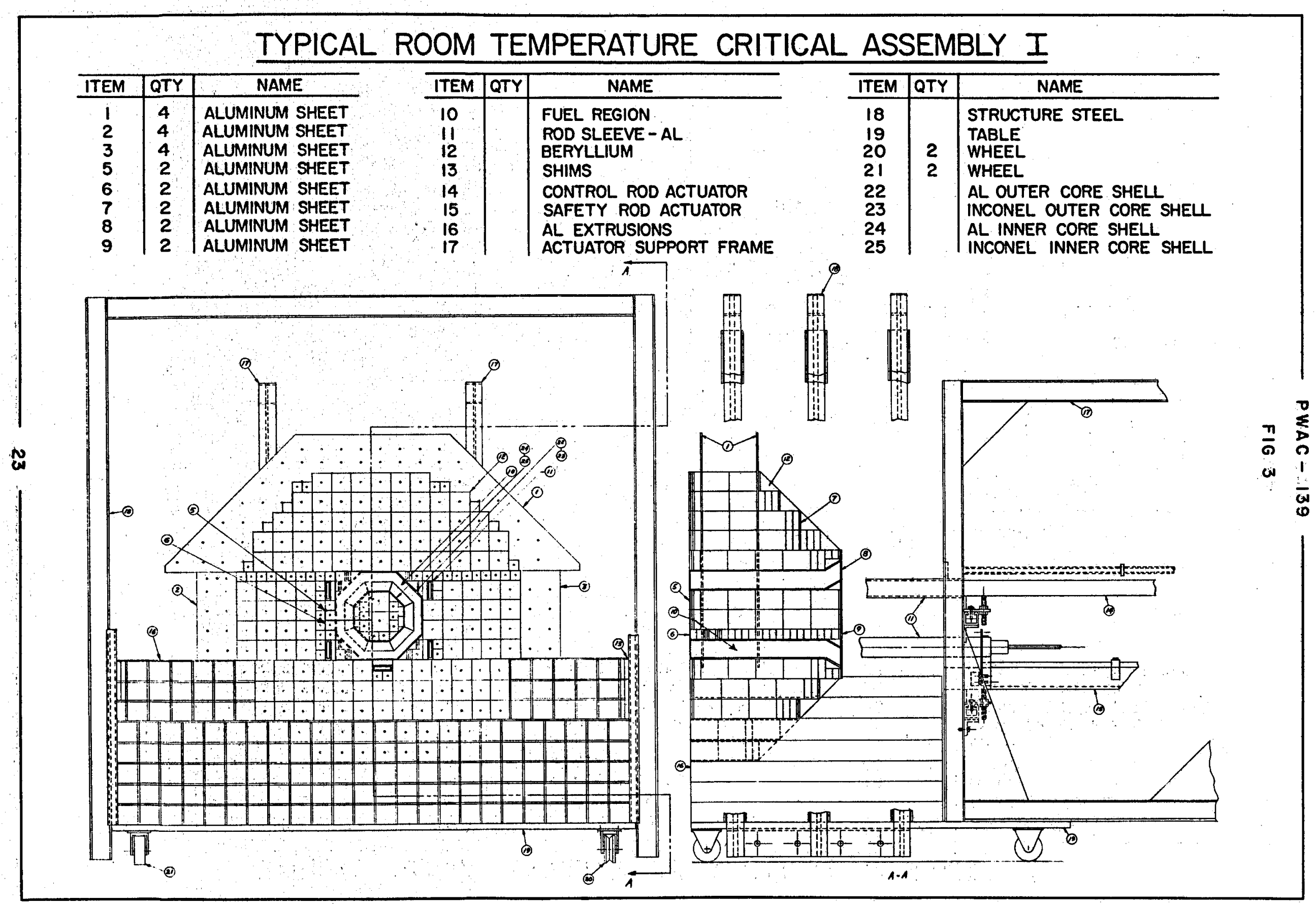


TYPICAL ROOM TEMPERATURE CRITICAL ASSEMBLY II

\begin{tabular}{c|c|c}
\hline ITEM & QTY & NAME \\
\hline 1 & 4 & ALUMINUM SHEET \\
2 & 4 & ALUMINUM SHEET \\
3 & 4 & ALUMINUM SHEET \\
5 & 2 & ALUMINUM SHEET \\
6 & 2 & ALUMINUM SHEET \\
7 & 2 & ALUMINUM SHEET \\
8 & 2 & ALUMINUM SHEET \\
9 & 2 & ALUMINUM SHEET
\end{tabular}

\begin{tabular}{l|l|l}
\hline ITEM & QTY & \multicolumn{1}{|c}{ NAME } \\
\hline 10 & & FUEL REGION \\
11 & & ROD SLEEVE-AL \\
12 & & BERYLLIUM \\
13 & & SHIMS \\
14 & & CONTROL ROD ACTUATOR \\
15 & & SAFETY ROD ACTUATOR \\
16 & & AL EXTRUSIONS \\
17 & & ACTUATOR SUPPORT FRAME \\
&
\end{tabular}

\begin{tabular}{c|c|l}
\hline ITEM & QTY & \multicolumn{1}{|c}{ NAME } \\
\hline 18 & & STRUCTURE STEEL \\
19 & & TABLE \\
20 & 2 & WHEEL \\
21 & 2 & WHEEL \\
\hline
\end{tabular}

AL OUTER CORE SHELL

INCONEL OUTER CORE SHELL

AL INNER CORE SHELL

AL EXTRUSIONS
ACTUATOR SUPPORT FRAME

INCONEL INNER CORE SHELL
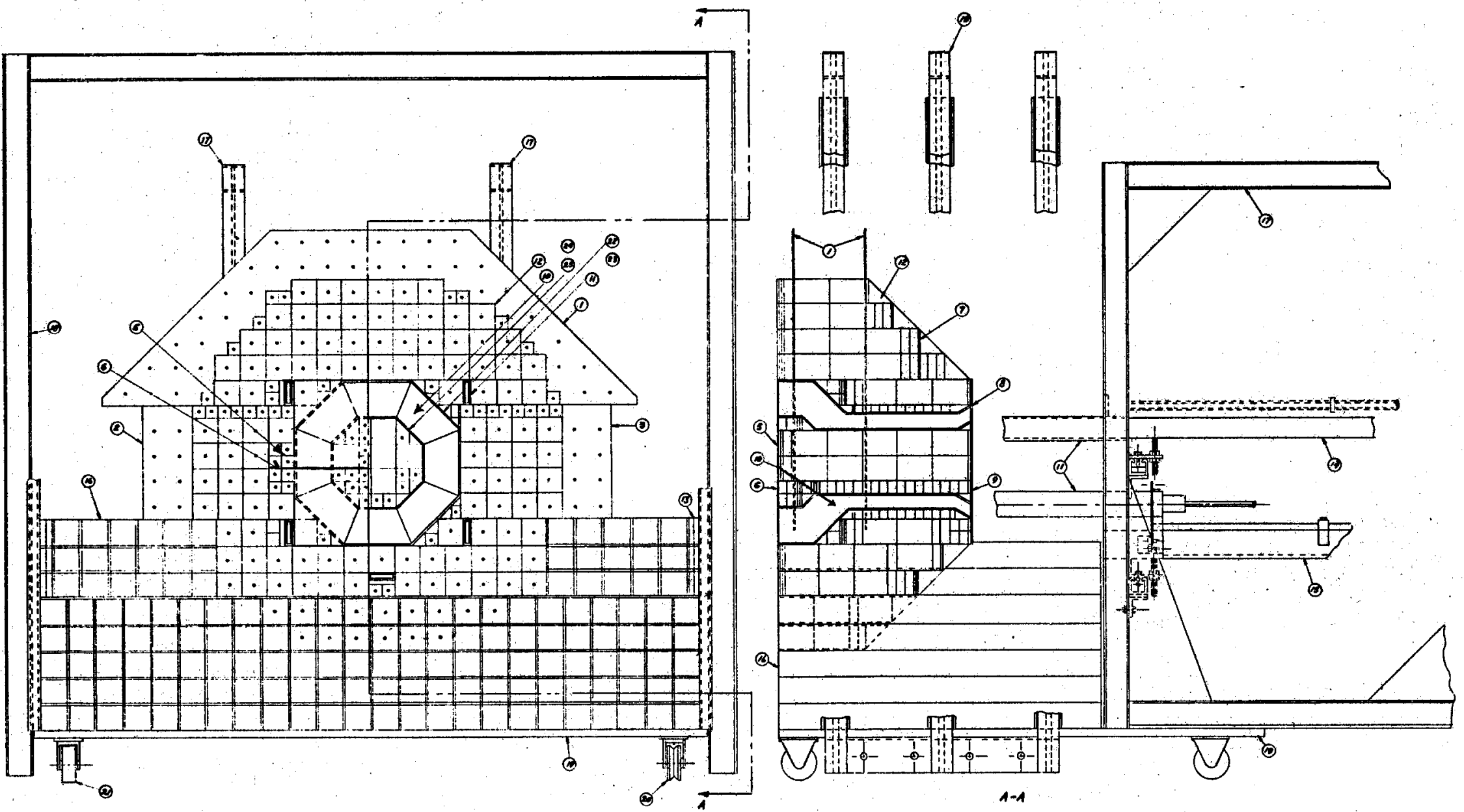
PWAC - 139

FIG 5

\section{SCHEMATIC DIAGRAM OF TABLE DRIVE}

TOP VIEW

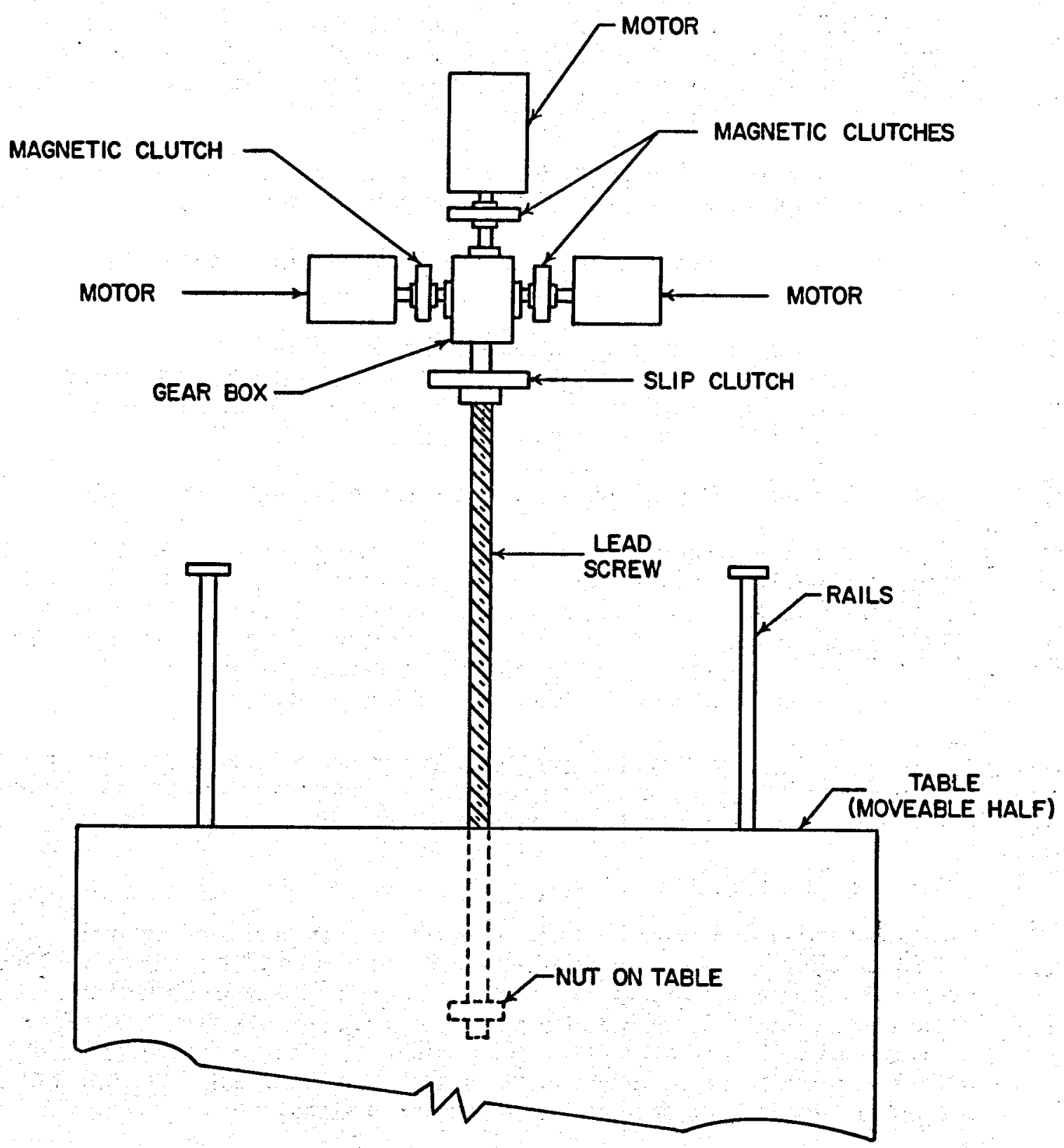


the table at a different speed. Limit switches actuated by the moving table half: will control the speed changes. An example of the resulting schedule of table closure is as follows:

(1) For a separation of 60 to 10 inches - - high speed only, 24 inches per minute.

(2) For a separation of 10 inches to 2 inches - - intermediate speed only, 6 inches per minute.

(3) For a separation of 2 inches or less - - low speed only, 1/2 inch per minute.

The schedule of table closure will be a compromise between speed for convenient operation time and slowness for reasonable rates of increase of reactivity. The schedule can be modified for different types of assemblies to limit the increase of reactivity to the order of 10 cents per second during the final portion of closure. Changing the schedule will require moving the limit switches and/or replacing the gear-head motors with others having different gear ratios.

Upon disassembly, either normal or scram, the movable half of the table will be driven out at the maximum rate (24 inches per minute) for the entire travel.

The position of the movable half of the table will be indicated on the control panel by devices typified by the following:

(1) A linear dial covering the full travel graduated in inches.

(2) A digital counter covering the full travel graduated in 0.01 inches.

(3) Counters or dials covering the last 0.5 inch of travel graduated in 0.001 inches indicating table separation on each side.

These indicators will probably be Selsyn-driven through suitable gearing.

The slip clutch between the lead screw and driving gears serves two purposes. First, damage from obstructions left between the halves will be minimized. Second, firm table closure can be obtained by driving the halves together until the clutch slips. Slipping will be indicated on the control panel by the flashing of a light connected to a commutator on the clutch. A ratchet (or equivalent) will preverit slipping of the clutch when the tables are being separated.

The limit switches will be installed in pairs in order to give very low probability of failure of the switching operations. In case of power fallure, the table drive will be operated from the emergency power supply.

c. Safety Rod Mechanism

The safety rods will be cocked one at a time by air pressure against springs and held magnetically. After cocking, the air pressure will be relieved. The condition of the air pressure and the in or out positions of the rods will be indicated on the control panel by a series of lights. Upon scram or power failure the magnet current will be turned off and the rods will fire. The rod mechanism will be adaptable to either poison or fuel-moderator rods. It is expected that the full rod travel will occur within 0.35 seconds after receipt of signal.

\section{d. Control Rod Mechanism}

Each control rod will be driven by a small limited-speed motor through a lead screw. Position of each control rod will be indicated on the control panel by lights for the extreme positions and for all positions by a digital counter graduated to 
0.01 inches or less and probably driven by a Selsyn. The motors which drive the control rods will be wired so that only one rod at a time can be moved to increase reactivity but all at once can be driven in the direction of decrease reactivity.

Some control rods may be spring loaded and driven through a magnet. The spring would tend to force the rod to a position of least reactivity. Thus upon scram or power failure the magnet would release and the rod would act as an additional safety.

e. Source Assembly

A polonium-beryllium source of approximately 10 curies will be used during operation and calibration procedures. The source will be mounted on a friction driven - rod traveling from a shield, through a tube in the stationary half of the reactor near the plane of separation, to approximately the center of the assembled reactor. Appropriate switches limit the travel and actuate lights on the control panel indicating the in and out positions.

3. Elevated Temperature Assembly

a. General

Fig 6 illustrates schematically an elevated temperature assembly. The reactor will be mounted with the axis vertical inside an insulated tank or oven to which heat will be supplied by electrical resistance heaters or by hot gases from a burner. Continuous Inconel shells on either side of the fuel region will serve to contain the molten fuel as in the power reactor. The beryllium island and reflector could still be composed of stacked blocks but more likely will be larger slabs machined to fit the smooth contours of the Inconel shells. A single poison control-safety rod worth at least four dollars will be inserted along the axis from the top. A source will be inserted to a point near the center of the reactor through a tube or down the center of the control rod. The fuel region will be connected through a pipe at the bottom to a fuel storage tank. The reactor will be elevated above the storage tank so that fuel dralning will be by gravity.

b. Fuel Handling System

The fuel handling system will consist of a fuel storage or sump tank, devices for putting charges of material into the tank, equipment for transferring the fuel to the reactor, the fuel region in the reactor, level sensing and indicating devices, and dump valving. An inert atmosphere of helium will be maintained over the fuel surfaces at all times. The fuel storage tank will have heaters to keep the fuel molten. Its geometry will be such that a subcritical condition exists with the storage tank full of enriched fuel. The charging device will essentially provide means of connecting a small tank containing a known small charge to the storage tank and admitting the charge while maintaining the inert atmosphere. Heating of the charge tank will be necessary. The micro-enricher will add controlled small amounts of enriched material. To mix the materials added to the storage tank a stirring system may be used although if nothing suitable can be designed, running the fuel partially in and out of the reactor several times will suffice. A connection for sampling the fuel will be provided. To raise the fuel into the reactor the helium pressure in the storage tank will be increased at a controlled rate. The level of the fuel in the reactor can be sensed by probes such as the "spark-plug" type, i.e., a probe depending upon the fuel electrically closing the gap between two projecting wires. Fixed probes will detect the fuel at limiting positions such as the lower and 
PWAC - 139

FIG 6

\section{SCHEMATIC OF AN ELEVATED TEMPERATURE CRITICAL ASSEMBLY}

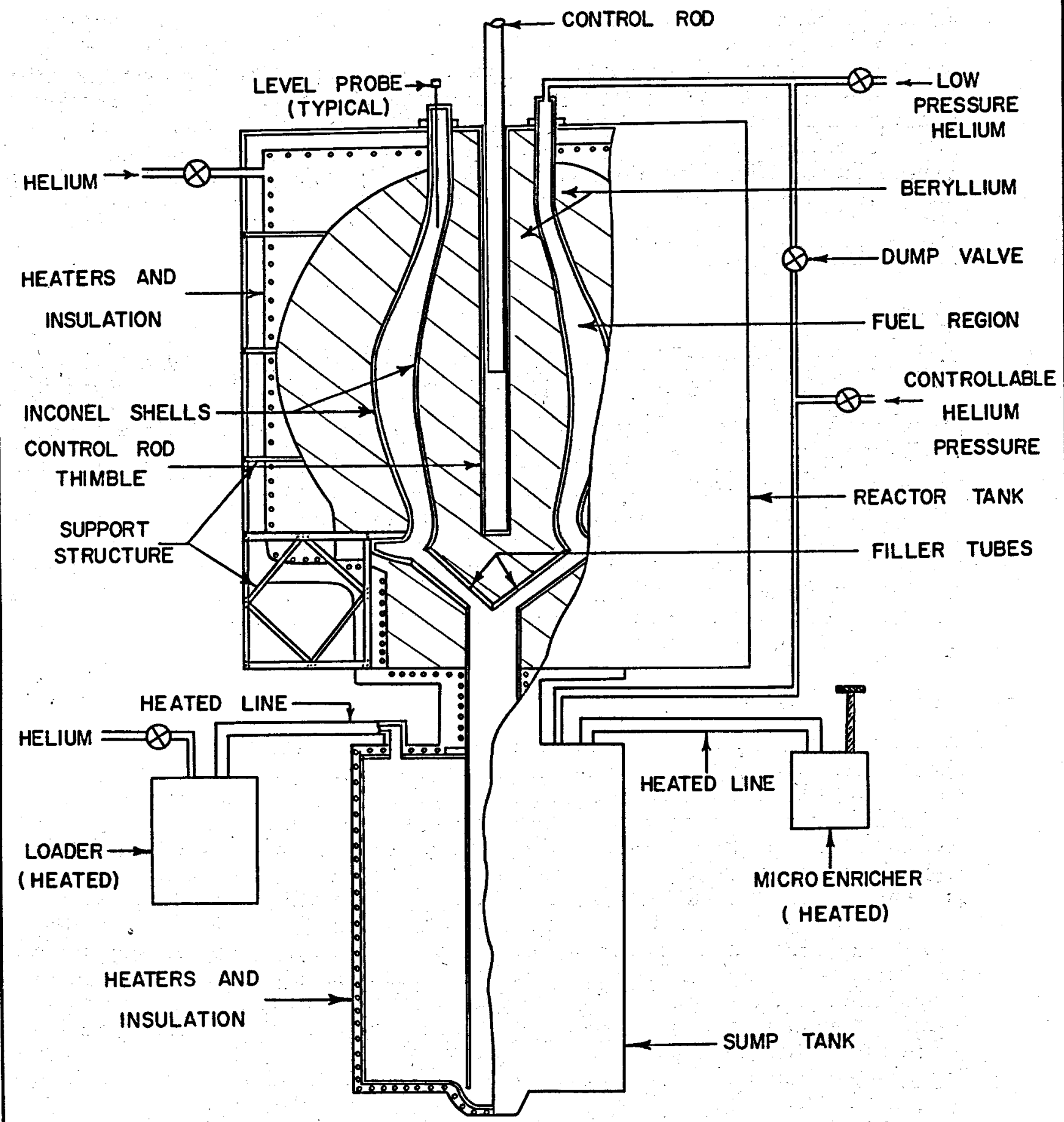


upper ends of the fuel region. Adjustable or remotely movable probes will be used for intermediate levels if suitable seals for the mechanism can be found. Dumping the fuel will be by valving the helium so as to equalize the pressure above and below the fuel. Pipe sizes and cold traps will be designed to allow for condensation of zirconium fluoride or other fuel constituents.

c. Control and Safety Rods

Control and safety rods could conceivably be similar to those in a room temperature experiment, but since a closer approach to final reactor design is desired, more likely there will be one rod entering axially from the top and serving both purposes. This rod will be lifted by a magnet mechanically driven as by a lead screw. Scram or power failure will interrupt the magnet current and drop the rod.

Only the upper $50 \%$ or less of the effective range will be used for control purposes so that during operation the remainder is always available for safety. The rod position will be indicated in the control room in a manner similar to that for the room-temperature experiment.

d. Source

If the control rod is hollow, the source can be inserted through the rod and project beyond the end of it. An alternate arrangement, which would have to be used if the control rod were not hollow, would be to have a special tube running to a point near the center of the reactor. Drive and position-indicating systems will be similar to those for room-temperature experiments. 


\section{INSTRUMENTATION AND CONTROLS}

1. General

The operational instrumentation will be essentially the same for most of the critical experiments contemplated so that the equipment described here is more or less universal. On the other hand, controls interlocks and events during scram are more specialized. The philosophy implied in the description of safeties for room temperature experiments will be extended to elevated temperature experiments as described in part below.

Consoles will be set up so that operating and safety switches and lights, position indicators, and key power-level and period meters and recorders will be grouped in front of the operator. Auxiliary counting and recording equipment will be to one side as will any special installation of secondary controls. In designing the consoles consideration will be given to ease of reading of indicators and recorders and to simplicity and naturalness of operating the controls. Switches will be arranged so that the up position corresponds to an increase in reactivity and must be maintained by holding against spring pressure. Down position will correspond to decrease in reactivity and in some cases will stay without holding. A red light will indicate a potentially hazardous condition and a green light a safer condition. The consoles will be arranged to allow operation while sitting.

Sound communication between control room and cell will be by two-way intercom system separate for each cell.

2. Operational and Control Instrumentation

The operational instrumentation for the critical assembly is shown in block diagram form in Fig 7.

All sensing elements, such as ion chambers, proportional counters, etc., used for control and safety purposes, will be mounted on or adjacent to the assembly and will have sufficient sensitivity to detect neutrons resulting from the presence of the source in its operating position with the assembly fully separated. Most of the sensing elements will be placed so that they are not exposed directly to the source when the table halves are apart. All sensing elements and their associated circuitry except some auxiliary gamma monitors and low range proportional counters will have sufficient range to operate from pre-startup background to above any operating levels.

For multiplication experiments and startups, there will be four scaler channels operating from $\mathrm{BF}_{3}$ proportional counters and/or fission chambers. The BF3 counters and fission chambers will be interchanged as desired according to experimental requirements. One channel will also incorporate a log count rate and period circuit as an operator convenience, and the other three will have additional audio outputs. All four channels will respond to multiplication of the source.

Three boron lined ion chambers will feed linear DC amplifiers and associated recorders. These amplifiers feed independent level signals to the safety circuits, and will respond to source multiplication. One amplifier may incorporate.a differentiator circuit and recorder to obtain rate of drift information as an aid to approaching steady level. The recorder on another amplifier may incorporate an optional zero suppression as an aid in detecting slow level drifts. 

$r$

\section{BLOCK DIAGRAM OF INSTRUMENTATION}

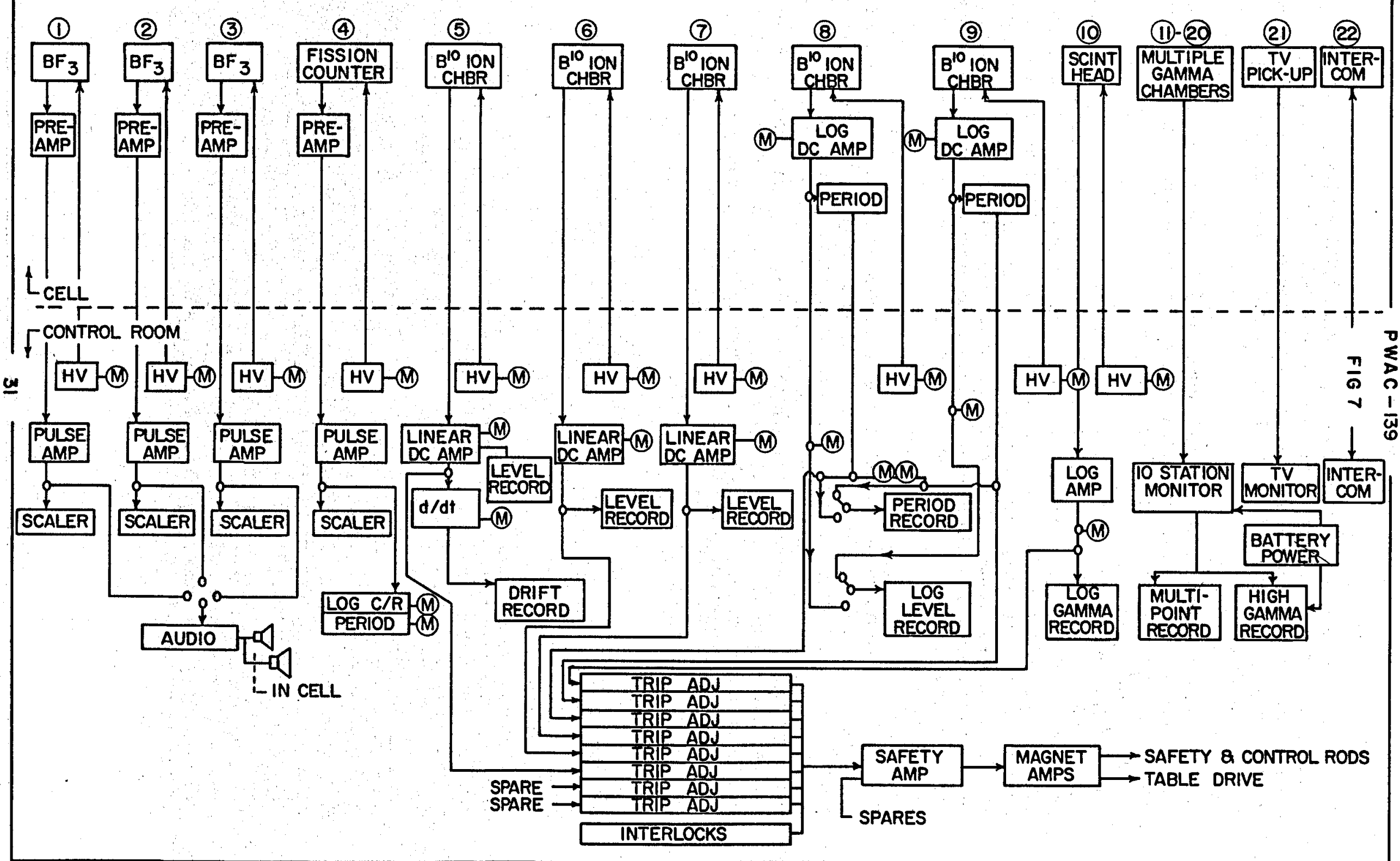


Two boron-lined ion chambers will feed logarithmic DC amplifiers and their period circuits. One log level recorder and one period recorder will be used in the channel desired, the other channel being used as an operating spare. Both period channels will supply signals to the safety circuits. These logarithmic channels will respond to source multiplication.

Gamma level will be detected by a photomultiplier scintillation head, a logarithmic circuit, and recorder. This circuit will also feed a level signal to the safety circuits and will indicate down to normal background.

Additional gamma monitoring will be available in several channels of a battery-powered multi-channel ion chamber monitor. Other channels of this instrument will monitor the control rooms, vaults, roof, filters, etc., and the associated multipoint recorder will be in view of the critical assembly operator. This instrument will also incorporate a battery or spring powered recorder to provide records in event of a building power failure. All of the circuit units, amplifiers, etc., as used in the above control, safety, and information channels will be of types and models proven in other similar installations.

\section{Safety Circuits}

The four level and two period signals enter the safety circuits as directly-observed high level signals. Variable attenuators permit adjustment of trip level. The safety amplifier acts as a mixer and auction circuit, the output of which operates the magnet amplifier. The magnet amplifier is the source of power to holding magnets for the rods. Loss of this power will also cause the table halves to drive apart. Several interlocks will also operate the safety circuit. The design of the entire safety circuit will be such that, insofar as possible, component failure will cause scram. Where this is not possible, duplicate circuitry will be used. 


\section{E. PLAN OF NORMAL OPERATION}

\section{Handling of Fissionable Material}

Fissionable material will be stored in the vaults, which will be operated as accountability substations. A staff member will have responsibility for keeping records on the location of this material. He and his appointed assistants will be the only persons normally having access to the storage section of a vault. Each piece or container of fissionable material will be labeled. Transfers will be recorded when material leaves or enters the storage section of a vault. Amounts will be marked on loading records when material is put into or removed from a critical assembly. Material that is in a critical assembly or the fuel system of an elevated temperature assembly will ordinarily be left there overnight since the test cells will be adequately secured.

2. General Operation of a Critical Assembly

Before assembling, changing, or operating a reactor assembly, the operating crew must agree unanimously that the planned procedure will be safe. Judgements should be based on analysis or extrapolation of past experience with related assemblies. For major changes the head of operations must also agree.

A critical assembly will normally have a three to six man crew. At least two operators must be present for any operation and three for non-routine operations. Again depending on the nature of tests, one or more of those present must be senior personnel selected on the basis of their experience, ability, and temperament.

The assembly will not be operated when background distractions are considered to constitute a hazard.

Before startup on any day, the response of all instruments will be checked against a portable source of known strength. Trip levels and minimum holding currents for magnets will be checked with cocked safeties by scramming with the portable source.

Before startup of any run the test cell will be cleared of people, the access doors closed and the warning signs changed to indicate reactor "on". Instruments will be turned on, the source inserted in the critical assembly, and the response of all instruments noted. All linear neutron detector $\$$ must respond to the presence of the source. The proportional counter channels will be audible.

Normal approach to criticality in the case of the room-temperature experiment will then proceed as follows: Safety rods will be cocked, one at a time, and the air pressure then turned off. Control rods will be put in the least reactive position. The reactor will then be brought to criticality by bringing the halves together and withdrawing the control rods in a series of increments. The period will normally be limited to a minimum of 30 seconds. The source will be removed and the control rods adjusted to bring the reactor to the desired power level. Power level will ordinarily be about one watt and occasionally on the order of ten watts. During the approach to criticality and desired power, the trip level will be increased to keep a factor of from two to ten between trip level and power level. Changes in multiplication and power level will be observed from meters and recorders as noted earlier.

Normal approach to criticality in the case of the elevated-temperature experiment will involve cocking the rod, slowly raising the fuel level, and slowly withdrawing the rod with the control mechanism. Details of the equipment and procedure are not yet available. 
Normal shutdown of the room-temperature assembly will be accomplished by inserting the control rods simultaneously if desired, and separating the table halves. After several minutes residual radioactivity will have decayed sufficiently to allow working directly with the reactor components. Activity levels will be checked each time with portable survey meters.

Normal shutdown for the elevated temperature assembly will be effected by inserting the rod and draining the fuel.

Normal loading changes will be limited to considerably less than the value of the safety system. Major changes will require following a procedure for initial approach to criticality.

A logbook will be maintained for each critical assembly. It will contain records of instrument checks, loading changes, procedures peculiar to a particular experiment, control settings, instrument readings, and any other information pertinent to future evaluation of procedures and data.

\section{Initial Approach to Criticality}

The initial approach to criticality with a new room-temperature assembly or one involving major rearrangement will start with assembling the pieces omitting the uranium or even providing a filler in place of the fuel material. Then the neutron source will be inserted and instrument levels read with the tables together and control rods removed. Next a small fraction of the expected critical mass will be inserted (with the tables apart) and the source multiplication measured as above. This will continue with conservative fuel additions until criticality is reached. A rule frequently applicable to the addition of fuel in this type of assembly is to limit the next increment of fuel to half the difference between the existing mass and the critical mass obtained from extrapolating a plot of the inverse of source multiplication versus mass to zero, but with an absolute limit on the amount added. Fuel addition will be by hand observing the following precautions:

1. A loading chart will be marked to indicate the status of the assembly.

2. At least one linear neutron detector and one proportional counter having audio output shall be operating and tended by a member of the operating crew.

3. A source will be present in the assembly whenever feasible and the safeties will be cocked.

4. Communication between the test cell and the control room will be maintained, and information concerning sudden or erratic change in neutron level will be relayed.

When source multiplication reaches a considerable value (say 10 ) and again at a very low power level after reaching criticality, the effectiveness of the controls and safeties will be tested.

Initial approach to criticality for the elevated temperature assembly will start from instrument readings with the source inserted with barren carrier in the fuel region. Source multiplications will then be measured with gradually increasing concentration of uranium until criticality is reached with the fuel region full and the control rod adjusted to desired position. Limitations on additions of uranium might be similar to those for solid assemblies although this will have to be studied. Precautions taken during loading, and testing of the effectiveness of controls and safeties will follow the same philosophy as for the room-temperature assembly. 


\section{F. TYPES OF EXPERIMENTS}

\section{Room Temperature Experiments}

\section{a. Determination of Critical Mass}

Usually the first version of a critical assembly is one with a minimum of poisons in order to determine the critical mass (of fissionable material) of a "clean" reactor as a base point. A critical mass will be determined automatically in the process of achieving criticality, since the mass in the assembly will be known. However, the mass will be further adjusted until criticality occurs with the control rods almost entirely removed to give a "clean" assembly. Subsequently the amount of fissionable material may be increased in obtaining critical mass of a poisoned assembly or in providing sufficient excess reactivity to permit other experiments.

b. Rod Calibrations

Calibration of control rods, whether operating rods for the tešt assembly or design reactor rods, will usually be based on either the period method or rod-drop method. After calibration of one or more rods, others may be evaluated indirectly by comparison.

Safety rods may be calibrated in the same ways although normally only by the rod-drop method.

c. Flux and Power Distributions

In order to obtain information on neutron flux distributions in space and energy, small amounts of materials such as gold, indium, manganese, cobalt, or sulfur, with and without a cover such as cadmium, will be inserted for activation. For power distribution, fission foils or aluminum "catchers" next to bare uranium will be inserted. Additional techniques using emulsions, probes, or counters will be used as available.

\section{d. Reactivity Coefficients}

The effect on reactivity of small additions of material representing fission product poisons, structure, coolants, additional fuel and the like can be evaluated by noting the change in the position of the calibrated control rods or by resulting periods.

\section{e. Temperature Coefficient}

The effect of small changes of temperature, about normal room temperature, will be obtained by varying the set point of the air conditioning system and noting the change in rod positions.

\section{f. Other Experiments}

Other experiments will include measurement of gamma ray energy dissipation rate, leakage from the assembly, and possibly activation of reactor materials. Of course the effect of changes in geometry and composition on all other properties will be sought. 


\section{Elevated Temperature Experiments}

Experiments at elevated temperature are less well defined by past example than are those at room temperature but are expected to include those discussed below.

\section{a. Determination of Critical Mass}

The determination of critical mass will be similar to that outlined above for the room temperature experiments.

b. Rod Calibration

The procedure for rod calibration will be similar to that outlined above for the room temperature experiments.

c. Flux and Power Distribution

Although insertion and removal of detectors will be considerably more difficult than in room temperature experiments, some tests of this type will be made. Heat-resistant forms of the internal detectors may have to be developed.

d. Reactivity Coefficients

The procedure for determination of reactivity coefficients will be similar to that outlined above for the room temperature experiments.

e. Temperature Coefficients

Temperature coefficients are one of the main objects of tests at elevated temperatures. Varying the temperature level and noting changes in position of calibrated control rods will give an overall temperature coefficient. Injecting the fuel at a temperature different from that of the beryllium will give some information on differential temperature coefficients.

f. Other Experiments

Other experiments will include measurement of gamma ray energy dissipation rate, leakage from the assembly, and possibly activation of reactor materials. 


\section{G. SAFETY MECHANISMS}

Safety mechanisms fall in two classes. In the first are those which will be inherent in the reactor or will be designed into the equipment and serve to reduce reactivity or limit the rate of increase of reactivity. In the second are items of accessory equipment such as monitors and interlocks to prevent unsafe operation. The scram system will combine features of both classes.

\section{Intrinsic Safety Features}

In the room temperature experiments the assembly will be split into widely separated halves during periods of loading, modification or idleness, and the chance of reaching criticality in one half will be very small. Table closure will be accomplished by motors having definite top speeds and connected to give decreasing speed of table motion as the tables come together. The lowest speed of table closure will start with the tables separated sufficiently to allow for a considerable amount of excess reactivity, and the lowest speed will be selected to limit increase of reactivity to the order of 10 cents per second.

In the high temperature experiments the fuel will be drained from the assembly curing periods of modification or idleness. This assembly is expected to have a negative prompt temperature coefficient of reactivity because of the thermal expansion of the molten fuel.

Both types of assemblies will have one or more safety rods with a total worth of about 5 dollars, which will take effect within about 350 milliseconds after scram is initiated.

Control rods will be driven by limited speed motors at a rate selected to give a maximum rate of increase of reactivity on the order of one cent per second. Only one rod at a time can be moved to increase reactivity but all may be moved together to decrease reactivity.

A neutron source will be inserted into any assembly before startup to provide an initial neutron level sufficient to give quick response in multiplication and to show on detecting instruments.

In the elevated temperature assembly helium pressure in the beryllium regions will be maintained higher than in the fuel region to prevent fuel from leaking into the beryllium region. Other features of this nature in this experiment have not been finalized.

\section{Scram System}

The reactor can be scrammed manually, by instruments, by interlock or by power failure. Manual scramming will be by means of scram buttons or pull cords to be located at convenient points in the control room and test cell. Instrument scram will occur if neutron flux or gamma radiation levels detected by the instruments exceed the preset trip levels. Interlock scrams will be caused during operation by opening test cell doors, turning on air pressure to safety rods of the room temperature assembly, having excess fuel helght or reversal of pressure difference across core shells in the elevated temperature assembly, or other hazardous conditions peculiar to particular assemblies. Any interruption in power to the controls or instrumentation will result in scram. 
When scram of the room temperature assembly is initiated by instruments or manual action, the following events will take place:

a. The safety rods will be released to shoot by spring force to their positions of least reactivity.

b. The table halves will separate at maximum rate, driven by a motor which will have emergency power available.

c. The dampers in air ducts to and from the test cell will close.

d. The ventilation system for the test cell will turn off.

e. The red "reactor on" lights in and around the building and at the access roads will flash.

f. Horn alarms in and around building will sound.

Power failure will result in the same events except e and f. Interlock scrams will cause only $a$ and $b$.

Scram of the elevated temperature assembly will result in the following events:

a. The control-safety rod will be released to fall by gravity to its position of least reactivity.

b. The gas pressure above and below the fuel will be equalized by opening an interconnecting valve, and the fuel will then dump by gravity into the storage tank below the reactor.

c., d., e. and $f$. pertaining to the ventilation system and alarms will occur in the same way as for the room temperature experiment.

After initiation of a scram, a return to normal operating conditions can be made only by resetting a lock-in relay in the unit in which the trip occurred.

3. Mechanisms to Prevent Unsafe Operation

Monitoring instruments will be provided to keep the operators informed of gamma radiation level and of neutron density and its rate of change over the whole range of operation and will initiate scram if these quantities exceed preset values. The detectors are placed to see primarily neutrons multiplied by the assembly. Counter-type monitors provide audible as well as visual indication of increased multiplication.

Interlocks that will be active during normal operation of the room temperature assembly are listed below:

a. Interlocks prevent the moving of table halves together until

1. Cell access doors are closed.

2. Internal and external test cell signs are changed to "on".

3. Critical assembly source is in. 
4. Safety rods are cocked.

5. Air pressure to safety rods is off.

6. Control rods are in the least reactive position.

Lights or position indicators will notify the operator which of these conditions have been satisfied.

b. Interlocks for control rod operation

1. Selector switch allows only individual rod operation in increasing or decreasing reactivity.

2. Collective switch allows simultaneous operation of all rods for decreasing reactivity only.

c. Interlocks for safety rod operation

1. Selector switch allows only individual cocking and firing of the rods.

2. Interlock on the air supply prohibits cocking of safety rods when table halves are not fully apart.

d. Interlocks initiating scram, if during operation any of the following occur:

1. Control power is interrupted.

2. Air pressure to safety rods is turned on.

3. Cell access doors are opened.

The same philosophy will be used in speclfying interlocks appropriate for the elevated temperature assembly.

Since interlocks must be overruled for maintenance and periodic checks, provision will be made for by-passing them on the front of the console so that the operator will always know which are in effect.

A pressure sensor in each test cell will cause dampers in the cell air ducts to close and the ventilation equipment for the cell to turn off whenever an appreciable pressure rise occurs. 
$E$

[

j

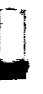

4

6

4

E

$U$

$[1$

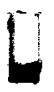

4

5

4 
PWAC - 139

\section{HAZARDS AND ACCIDENTS}

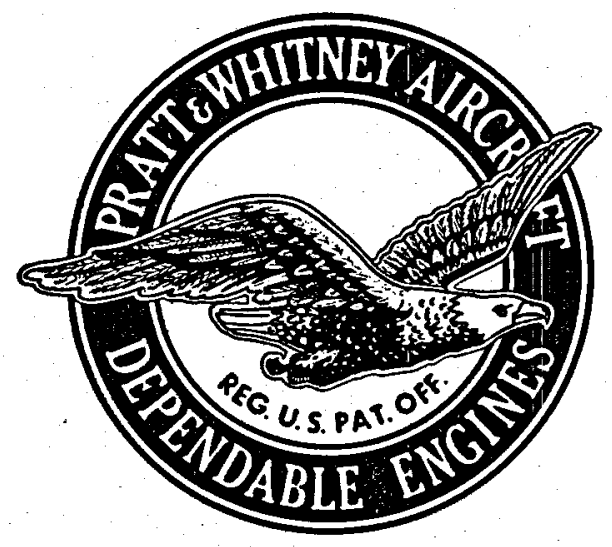




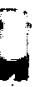

1

4

$+$

4

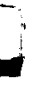

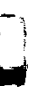

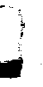

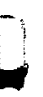

$+$

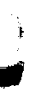

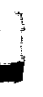

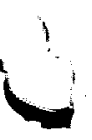




\section{A. POTENTIAL HAZARDS AND COUNTERMEASURES}

Hazardous situations in the critical experiments could occur as a result of action by personnel, malfunction of equipment, possible autocatalytic characteristics, or catastrophes such as fire, flood or earthquake. Two or more of these would have to occur in conjunction in order to cause a damaging accident. These potential causes are elaborated upon below along with their countermeasures.

\section{Action By Personnel.}

In the normal course of putting together and modifying a room temperature critical assembly errors in loading might be made which would result in a supercriticality, either during loading or with the halves coming together rapidly while the gap between is still large. This is protected against by:

a. loading the assembly in halves so that the error to reach criticality would have to. be very great,

b. having a written plan for the loading changes,

c. maintaining a loading diagram and other records of loading changes,

d. checking the amount of fissionable material leaving the storage vault,

e. having the reactor materials marked where necessary to ensure identification,

f. having instrumentation turned on so that multiplication will be indicated at the console and audibly in the cell,

g. having safety rods cocked and source inserted when feasible.

Similar considerations apply to the elevated temperature experiment, with the table separation feature replaced by fuel removal.

Insertion of measuring devices or the presence of people near the reactor could result in appreciable changes in reactivity. These effects will be estimated beforehand or determined experimentally in small increments.

Removing poisons by hand could cause rapid increases in reactivity. The value of such poisons will be determined experimentally as they are put in and if great enough to involve hazard, arrangements will be made to mechanically prevent rapid withdrawal of the poison. For example, a valuable control rod to be calibrated in addition to normal operating rods will be connected to a mechanical drive system similar to that for normal rods.

In the control room personnel can operate the wrong control, do things in the wrong order, make mistakes in calculating desirable changes, ignore or fail to see warning signals, or fall to take corrective action. Chances of such improper actions are reduced by designing the control console for easy reading, natural control motions and repeated indication of neutron levels and rates of change. To counteract improper actions a number of interlocks will be provided, as described earlier, which will require that steps such as cocking safeties, inserting a source, etc be done before the halves can be brought together (or fuel injected). If the reactor becomes supercritical 
before expected or noticed by the operators, monitoring circuits will initiate scram before dangerous power levels are reached. Violation of some of the interlocks will also cause scram as described above.

Another type of action by personnel is improper altering of the equipment either through error or by intention for the sake of "expediency". Most of the equipment will be arranged so that either it is difficult to change or requires deliberate action to reach. For example, changing table or rod drives requires changing motors, gears inside a gear box, or lead screws, or moving limit switches. Instrumentation and control equipment, relays, connectors, etc in the control room will be enclosed in cabinets. Thus there is small chance of altering equipment without having knowingly worked on it. Trial of the components involved will be made under safe conditions to check the results of any servicing or planned alteration. Routine pre-operational checks will also disclose most faulty operations. By-passing of interlocks is made obvious by the arrangement on the console described earlier. Of course no physical blocks exist that will prevent all intentional improper alterations or by-passing of safety procedures.

In order to reduce the risk of occurrence of improper actions by personnel, importance will be placed upon providing the right type of people, suitable working conditions, emphasis on safety, and procedures for expediting safe practices. Preliminary reports will usually be written for safety check before an experiment. Selected senior personnel will be primarily responsible for judging and maintaining safety but must respect the opinions of others in the operating crew. Two or more members of the crew including some senior personnel must be present for operation. Proper working conditions and fitness of personnel must be established before operations proceed. Check lists will be provided to assist checking-out equipment.

Improper actions by people can occur intentionally with malice to the extent of wishing to cause extensive damage with accompanying hazards to others. Such actions are classed as sabotage. Any action mentioned above could be done intentionally, but a clever saboteur might think of more or combine several. In addition to creating a loading of high reactivity by adding fuel or reflector, removing poisons, or rearranging parts, a saboteur might alter the table drive (or fuel injection) system to give excessive speed. He might jam or by-pass the safety rod mechanisms so that they could not fire the safety rods. He might replace absorbing rod materials with fuel or moderator (or vice versa). He might by-pass the scram circuit or alter instruments to falsely indicate power levels low. He might arrange to expel the control rods rapidly with explosives after the assembly is critical. He might also arrange for achieving criticality with poison safety rods inserted and expel them in the same manner. Finally, there will be sufficient fissionable material in the reactor or in the vault to build a supercritical assembly of some other type using other mechanisms.

There are a number of reasons why the chance of sabotage sufficient to cause a serious disaster is very small. The Nuclear Physics Laboratory will be within a "Q cleared" area having appropriate guard posts, patrolled fences, etc. All persons legally entering the building must have been previously granted a special security clearance and must have received at the guard post the appropriate exchange badge. During non-working hours entrances and exits for the test cells and the vaults for fissionable material (and portable sources) will be security alarmed, doors to control rooms will be alarmed or sealed, and a security guard will patrol the remainder of the building. Entrances to cells and vaults will have three-way combination locks. Consoles will be key-locked. Even if the saboteur were one of the persons having ready access to the area, he would still have great difficulties to overcome. A considerable amount of time and work would be involved in accomplishing enough of the changes listed above to cause a serious disaster. It is not likely that he could do 
this unobtrusively, and probably he would need the agreement or even the help of someone else in the group - - an extremely improbable situation. Pre-operational checks would uncover most acts of sabotage.

2. Malfunction of Equipment

A strong effort will be made to design equipment to fail safe. Monitoring circuits are numerous enough to provide continued protection even if several fail. In case of power failure a battery-operated monitor will continue to work. Power failure will also result in de-energizing motors, magnetic clutches and handling devices so that control and safety rods will be fired by spring pressure or gravity and normal table drive stopped. Emergency power will be available to drive the table apart. Limit switches, rod drives and other important equipment in the cell will be mechanically protected against damage. Switches, relays, etc will, where possible, be wired to fail safe. In case of exceptions multiple switching will be used in which chance of simultaneous failure is remote. In the case of the elevated temperature assembly, leakage of fuel into the beryllium regions upon rupture of the core shells under normal operating conditions is prevented by having gas pressure in the beryllium regions exceed fuel pressure. Lines supplying gas to the fuel filling system will be restricted in size to limit the rate of filling in case of failure of pressure regulators. Using good equipment, servicing it regularly, checking it often before startup, ano ibserving its behavior during operation will make multiple system failure extremely improbable.

\section{Possible Autocatalytic Characteristics}

It is possible but not known that the assemblies have any significant autocatalytic properties under usual operating conditions. No sensible heating is expected in the room temperature assembly so that if a small positive temperature coefficient of reactivity existed it would be of no consequence at least until an accident had already started. The prompt temperature coefficient of the fuel in the elevated temperature assembly is expected to be negative. The overall temperature coefficient would apply only to relatively slow changes and is also expected to be negative.

Leakage of fuel into the beryllium region of the elevated temperature assembly might result in an appreciable increase in reactivity and a low energy chemical reaction. This is prevented by maintaining higher pressure of helium in the beryllium region. Exposure of molten fuel to the air would result in no significant chemical reaction.

Additional autocatalytic features under conditions of runaway are discussed in a later section.

4. Flood, Fire, and Earthquake

Possibility of accidents being caused by natural flooding is eliminated by having the building on land where water cannot stand. Other flooding is prevented by having no water lines or drains in the test cells (or vaults).

Damage by fire will be minimized by keeping unnecessary flammable materials out of the cells. The uranium sheet used in the room temperature assembly will burn in the presence of air if sufficiently hot. The molten fuel to be used in the elevated temperature assembly has negligible reaction with air and only small reaction with beryllium. It seems very unlikely that these reactions could lead to a nuclear hazard.

Earthquakes have occurred in the area but the chance of reoccurence is considered slight. The cell structure should be quite adequate, and no distortions in the assemblies 
serious enough to make safeties inoperative are anticipated. Even if such distortions could occur in the room temperature assembly, the accompanying loosening of reactor parts should decrease the reactivity. 


\section{B. INFORMATION USED IN EVALUATING HAZARDS}

This section presents a brief summary of the reactor characteristics which are used to evaluate accidents described in the next section. In the calculations it is assumed that one dollar is equivalent to $0.75 \%$ of reactivity, although the actual value is expected to be somewhat larger. It is assumed that experiments involving control rods will not introduce more than $4 \%$ of reactivity. Although control rods worth a larger amount are expected to be tested, experiments will be designed so that not more than $4 \%$ can possibly be introduced without rebuilding the assembly. The maximum rate of reactivity insertion by control rod motion is taken to be one cent per second. Variation of reactivity with separation between halves of an incomplete assembly has not been calculated. Use of this information has been avoided by making the conservative assumption that assembly is complete before an excursion is initiated. The effect of homogeneous mixing of Inconel core shells with fuel is approximately a $6 \%$ increase in reactivity. Homogeneous mixing of the core shells could only occur at very late stages of an excursion, if at all, so that quantitative use of this characteristic has not been made. Numerical calculations of the change of reactivity with volume give

$$
\frac{d k}{k}=-0.15 \frac{d v}{v}=-0.45 \frac{d r}{r}
$$

The mass coefficient of reactivity used in estimating the effect of expansion of the fuel in the elevated temperature assembly is taken as

$$
\mathrm{M} \frac{\mathrm{dk}}{\mathrm{dM}}=0.21 \text {. }
$$

The prompt neutron lieftime resulting from numerical calculations is $4 \times 10^{-4}$ secs for both assemblies. The prompt temperature coefficient for the elevated temperature assembly is indicated by a related experiment to be negative and not less than $2 \times 10^{-5} \mathrm{k} / \mathrm{deg}$.F. Other pertinent information used in the next section will be given in the table of Appendix $A$. 


\section{DAMAGE AND RADIOACTIVITY RELEASE IN CASE OF FAILURE}

1. General

It has been shown above that a compounding of several fallures would be necessary to produce a serious reactor power excursion. Based upon the remote possibility that such combined failures could occur, a number of accidents have been selected for analysis to determine corresponding damage to the facility and release of radioactive fission products. The conditions assumed to produce these accidents involve partial or complete failure of safety systems and procedures and exaggerated conditions of excess reactivity and operator negligence of sufficient degree to include results of sabotage. Also, it is believed that the total effects of the simplifying assumptions in the analysis are an over-estimate of consequences. The methods of analysis are subject to further refinement along with development of details of the experimental assemblies. Results of such extended analysis of accidents will be included in future reports to the committee regarding particular critical assemblies.

The accidents chosen for analysis are those resulting from:

(1) gradual introduction of $4 \%$ excess reactivity,

(2) sudden introduction of $4 \%$ excess reactivity, and

(3) sudden introduction of $25 \%$ excess reactivity.

Case (1) is further subdivided according to whether shutdown is accomplished by delayed scram or self-disassembly. All three cases are analyzed for the room temperature assembly and the first two for the elevated temperature assembly.

Gradual introduction of $4 \%$ excess reactivity can be considered to correspond to continuous removal of a poison control rod worth $4 \%$ by a rod drive mechanism. In the room temperature assembly no single operating control rod will be worth this much, so that the continuous removal postulated implies removing one rod after another. The rod actuating switch is arranged so that this would have to be done deliberately by the operator. A special experimental control rod to be evaluated might be worth $4 \%$ but would normally be connected so that no more than a fraction of the reactivity would be available without rearrangement of the drive mechanism. Similarly, in the elevated temperature assembly a rod having a value of $4 \%$ over the control portion will be an exceptional case and even then the extent of travel would be limited to cover only a portion of the range. Nevertheless, it is presumed that through poor management or faulty equipment the full $4 \%$ is available and is continuously introduced. Of course, scram will easily overcome the effects of the control rod motion if it occurs promptly as it should. If this fails also, a runaway results.

Sudden introduction of $4 \%$ excess reactivity can be considered to correspond to rapid removal of a valuable poison rod either by hand or by a charge of explosives (sabotage). As stated above, any valuable rod will be connected to a drive mechanism such as a lead screw. Therefore this case presumes that the drive mechanism has been disconnected and removed and the rod then withdrawn. That this would occur with the reactor assembled implies major violation of operating procedure and interlocks. If the safeties fail or the rod is removed extremely rapidly, shutdown must occur by self disassembly.

An excess reactivity of $25 \%$ can be considered to correspond to a serious error in loading the room temperature assembly. One slightly plausible mistake leading to this 
condition would be the installation of aluminum core shells in an assembly designed for Inconel shells. Prescribed procedure after a reloading of sufficient extent to allow the insertion of a core shell will be to follow the schedule for initial approach to criticality. If this were violated and all of the fuel inserted, with the expectation that only a minor change had been made, the condition would still be easily detected during the subsequent approach to criticality and the reactor shut down. To produce an accident, therefore, the additional failure of operator control and scram mechanisms must be postulated. To simplify analysis, it is assumed that the excess reactivity is introduced instantaneously. This should give pessimistic results and should cover any conceivable form of sabotage.

Events during and the results of these accidents will be described in the following sections.

\section{Room Temperature Assembly Accidents}

a. Gradual removal of an experimental control rod worth $4 \%$ from an already critical assembly:

The control rod is driven by a constant speed motor, set to give a removal rate of not more than one dollar's worth of reactivity every hundred seconds. Under certain cataclysmic conditions; presumably, the rod can fail to stop as desired and keep moving out. If at the same time the monitoring instruments fail to initiate scram, the nuclear power will rise with increasing rapidity until scram is initiated manually. Since the worst accident is that which gives the shortest period, that is, the least time for manual shutdown to be achieved, the case is considered where the rod begins to move out when the reactor is just critical with the rod still almost fully inserted. Power at this time is assumed to be $10^{-2}$ watts. As the rod moves out the reactor becomes supercritical, the power rises, and the period decreases. All of this is assumed to happen without eliciting any response whatsoever from either of the two operators in the control room.

When the power reaches about 25 watts the survey meters are reading higher than $1 \mathrm{r} / \mathrm{hr}$ in the test cell and a warning is set off in the control room. The level of 25 watts is reached at a time 75 seconds after the initiation of control rod motion. Fig 8 shows the variation of power and total energy generation with time. Appendix A gives the reactor constants used in the calculations. If one assumes that the manual scram is initiated 19 seconds after hearing the alarm in the control room, the power is $1 \mathrm{MW}$ and the total integrated energy is 1000 BTU. Shutdown occurs with the reactor intact and no fission products are released.

Supposing that manual scram is not effective, the reactor will have to shut down by self-disassembly. This is achieved only when the reactor geometry has changed sufficiently to overcome the excess reactivity which has been added by removal of the control rod.

There are two ways by which the reactor volume is increased (thus also increasing leakage). One is the expansion of the Teflon, Fig 9, and the other is vaporization of the uranium. Because of the close packing of uranium foil and Teflon it seems unlikely that uranium melting (and leaking out of the assembly) will cause shutdown. The mechanism which actually prevails depends on the heat conductivity between the uranium and the Teflon. For the accident under consideration it is assumed that $25 \mathrm{~kg}$ of uranium in the form of $4 \mathrm{mil}$ folls is contained in a core volume of 4 cubic feet, the thickness of Teflon between foils being 0.3 inches. 


\section{EFFECT OF CONTINUOUS ROD REMOVAL ON POWER, ENERGY AND PERIOD}

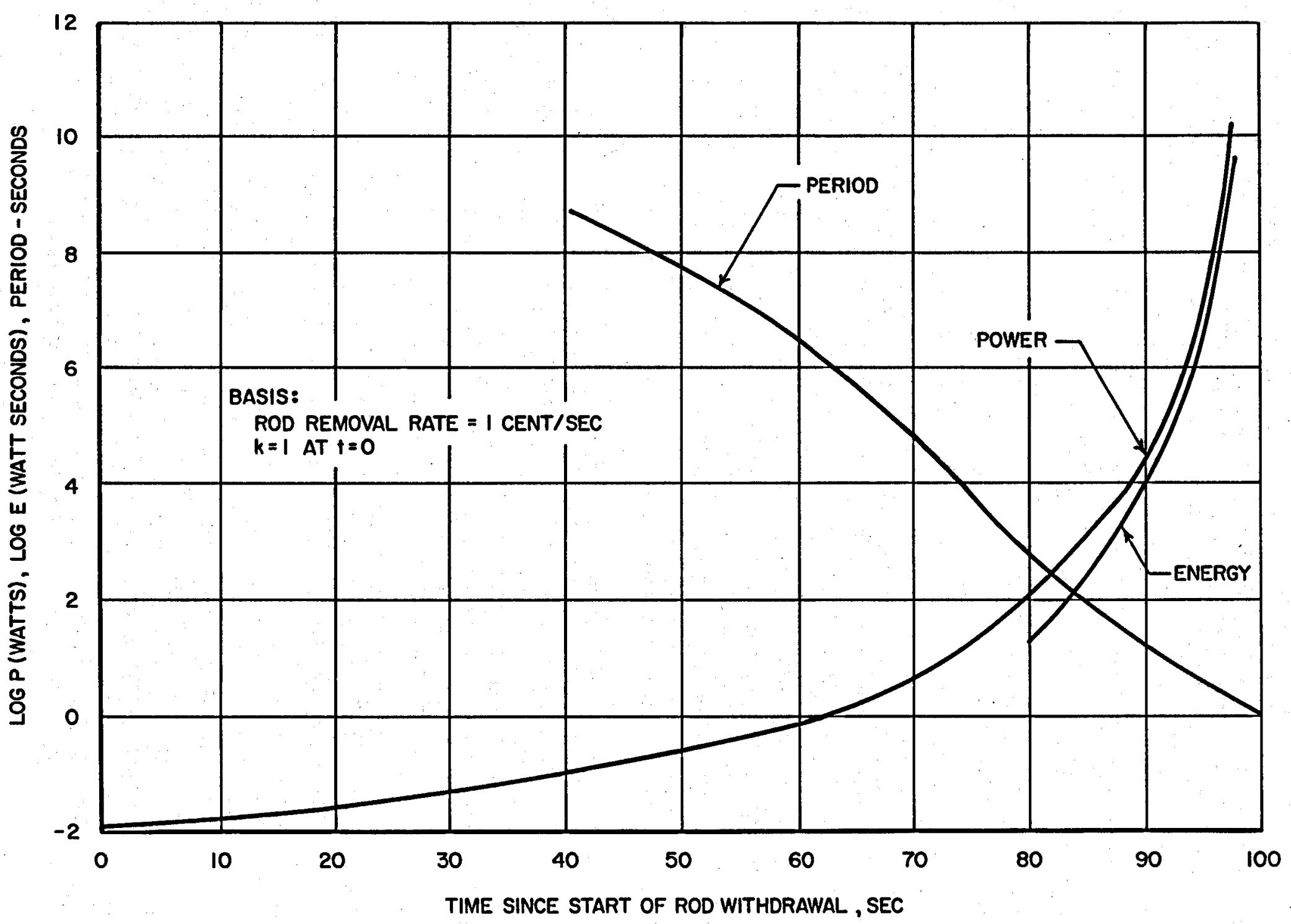




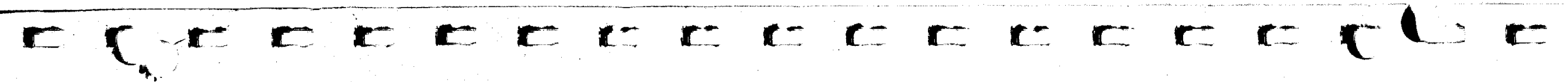

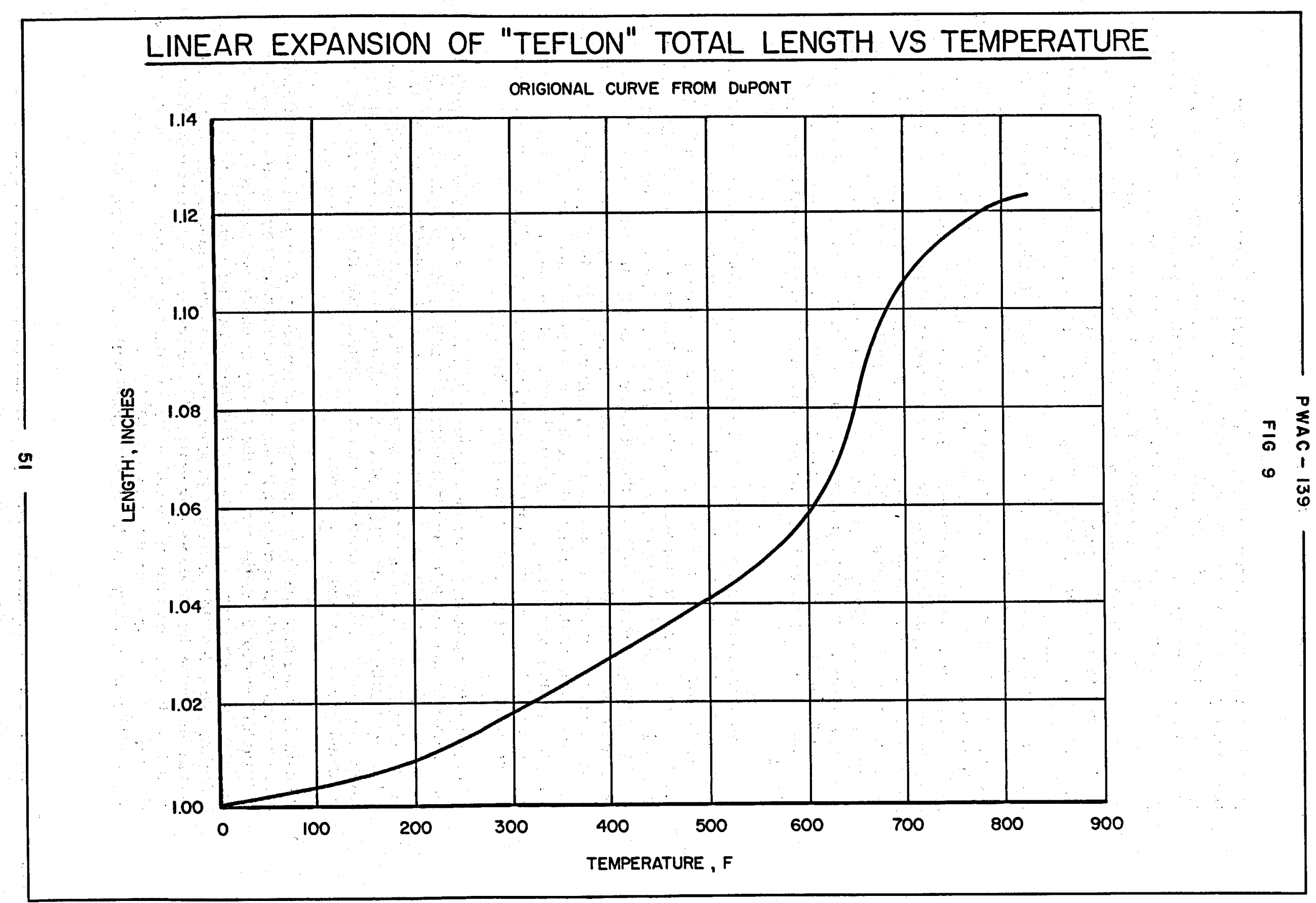


First it is assumed that there is poor conductivity between uranium and Teflon, so that disassembly is by uranium vaporization, ie, the Teflon remains at room temperature. It requires $1.5 \times 10^{4} \mathrm{BTU}$ to bring the $25 \mathrm{~kg}$ of uranium to the boiling point. By the time this much energy is generated the power level is $30 \mathrm{MW}$ and the period is less than one second. It would require less than one second more to volatize all the uranium, although this much uranium vapor is not needed for disassembly. At the power level of $30 \mathrm{MW}$ the uranium is evaporating at the rate of $3 \times 10^{4}$ cu ft per sec (atmospheric pressure) and must escape at about this rate if the reactor is not to be disassembled by the pressure of the vapor. Since the beryllium reflectors as a whole are not fastened to the tables, they can be pushed apart by any pressure which is sufficient to overcome their inertia (neglecting friction). The velocity of sound in uranium vapor is about 500 feet per second, so that a free flow area of $60 \mathrm{sq} \mathrm{ft}$ must be presented in order for the vapor escape rate from the assembly to be equal to the vapor generation rate. No amount of voids presenting anything like this surface can be postulated. It is therefore seen that the uranium vapor will push the reactor apart very rapidly. The mathematical formulation of this disassembly problem is given in Appendix A. It is found from the calculation that $1 \times 10^{4} \mathrm{BTU}$ are generated before the reactor has expanded sufficiently to shut itself down. Although exact criticality has again been attained the power level is now very high so that the reactor continues to generate energy, volatilize uranium, and expand while the power is dropping to zero. During this downward portion of the curve it is estimated that the total heat will be doubled. The total heat generated is therefore $5 \mathrm{x}$ $10^{4}$ BTU.

If the transfer of heat from uranium to Teflon is good, Teflon expansion will shut down the reactor. It is assumed that temperature distributions in each of the materials, uranium and Teflon, are flat (although, of course, not equal). Under these circumstances the temperature rise in the Teflon is estimated to be approximately $10 \%$ of the temperature rise in the uranium. When the uranium has reached its boiling temperature, $7000^{\circ} \mathrm{F}$, the "average" Teflon temperature is $600^{\circ} \mathrm{F}$ which is not quite enough to shut down the reactor. Even so, it is likely that due to the "real" temperature distribution in Teflon, which actually is not flat, the volatilization of Teflon near the uranium will expand the core and shut down the reactor before the uranium vaporizes. $1 \times 10^{5} \mathrm{BTU}$ are required before expansion is sufficient to remove $4 \%$ in $\mathrm{k}$. Again this must be doubled, to $2 \times 10^{5} \mathrm{BTU}$, in order to take into account the heat generated during sub-criticality.

A conservative estimate of the maximum heat generated is obtained by requiring the reactor to shut down by both mechanisms together, ie, about $2.5 \times 10^{5}$ BTU. No matter which mechanism is used, the uranium will probably at least be above the melting point. After the reactor is destroyed this uranium will oxidize in air, releasing another $1.2 \times 10^{5}$ BTU. Since the additional energy due to oxidation is ample to vaporize all the uranium, we must assume that all fission products are released into the test cell as a vapor.

To calculate the increase in temperature and pressure of the air in the test cell it is assumed that all of the heat put into the uranium plus the heat of combustion is transferred rapidly to the air. In the case just described this is $1.7 \times 10^{5} \mathrm{BTU}$ which gives a temperature increase of 210 degrees $F$ and a pressure rise of 5.7 $\mathrm{lb} / \mathrm{sq}$ in. To calculate the fission product release to the atmosphere, it is assumed that all of the fission products mix uniformly with the air in the test cell and then enough of the air flows out of the cell to relieve the excess pressure. In the present case, this means that of the $16.4 \times 10^{18}$ fission nuclei produced (from

$8.2 \times 10^{18}$ fissions) $21 \%$, or $3.4 \times 10^{18}$ nuclei will enter the atmosphere. 
b. Instantaneous introduction of $4 \%$ excess reactivity into a reactor already critical all interlocks and safeties simultaneously inoperative:

The resulting accident is essentially equivalent to an accident which one might envision for a reactor containing $4 \%$ excess $k$ assembled without a source. In this situation, with generation time equal to $4 \times 10^{-4}$ seconds, the power rises with a period of 10 milliseconds. Assuming no transfer of heat to the Teflon, the reactor shuts itself down when the uranium vapor pressure is sufficient to push the reflector away. The total heat generation before $\mathrm{k}$ is again equal to unity is $2 \times 10^{4}$ BTU. As the power drops to zero, approximately this much more energy is also generated. The total heat release is then $4 \times 10^{4}$ BTU. Oxidation of all the uranium adds $1.2 \times 10^{5}$ BTU additional energy. Due to energy released by oxidation we must assume that all the fission products are present in the test cell in vapor form.

This excursion results in a temperature rise of 200 degrees $F$ and a pressure rise of $5.4 \mathrm{~b} / \mathrm{sq}$ in. Of the $2.6 \times 10^{18}$ fission nuclei formed $20 \%$, or $.52 \times 10^{18}$ nuclei will be exhausted.

c. Instantaneous introduction of $25 \%$ excess reactivity with safeties inoperative:

Let it be supposed that each half of the assembly, constructed on a separate table, is by itself sub-critical. Depending on the speed of approach of the tables, it may be possible to completely assemble the system before the excursion shuts itself down. In order to obtain an estimate which is surely conservative; and to simplify the assumptions regarding table speeds, gas flow areas, and state of criticality of two separated tables, the question has been treated as if $25 \%$ excess $k$ were inserted instantaneously. In any case, the shutdown will depend principally upon motion of the moderator since the surfaces of the fuel region at the plane of separation have a combined area of only $2 \pi \mathrm{sq}$ feet. It has been seen that something like ten times this area must be available for pressure relief in order to avoid moving the moderator. Again there is some uncertainty concerning heat flow into the Teflon. One might suppose that the rapid rise of power associated with such a large excess reactivity would leave very little time for heat flow to take place. It is true that the power rises yery rapidly, but the time to shutdown is not exceptionally short in this case, due of course to the large expansion which must takes place tefore $k$ is again equal to 1 . On the basis that no heating of Teflon takes place, the energy developed by the time the power has returned to zero is $1.4 \times 10^{5}$ BTU. This requires complete vaporization of the uranium. Undoubtedly some of the Teflon is heated which, by increasing the pressure, will reduce the time required. The energy is probably increased thereby, perhaps by a factor of two. Oxidation of the uranium adds another $1.2 \times 10^{5}$ BTU, for a total of about $4.0 \times 105$ BTU.

This excursion results in a temperature rise of 490 degrees $F$ and a pressure rise in the cell of $13.5 \mathrm{lb} / \mathrm{sq}$ in. Of the $18.3 \times 10^{18}$ fission nuclei formed $37 \%$ or $6.8 \times 10^{18}$ nuclei will be exhausted.

\section{Elevated Temperature Assembly Accidents}

a. Gradual removal of an experimental control rod worth $4 \%$ from an already critical assembly: 
The accident proceeds exactly as the accident for the room temperature assembly until sufficient heat is generated to affect temperatures. Again, manual shutdown can be effected shortly after a 25 watt power level is reached. Scram is accomplished both by insertion of safety rods and by dumping the liquid fuel. If manual shutdown is not achieved, the power will keep rising until the reactor shuts itself down, in this case by expansion of the liquid fuel into the storage tank against helium pressure, or in the extreme by partial vaporization leading to displacement of the beryllium moderator as well. The liquid boils at 2250 degrees $F$, while the normal operating temperature is 1250 degrees $F$, so that the temperature may rise 1000 degrees before vaporization commences... Since the assembly has a temperature coefficient of reactivity, $\mathrm{dk} / \mathrm{dT}=-2 \times 10^{-5} / \mathrm{F}$, it is possible to counteract $2 \%$ in $\mathrm{k}$ without boiling the fuel. One obtains the total energy from an integration of the power over time taking account of the twofold change in $\mathrm{k}$ (the increase with rod withdrawal less the decrease with temperature). Provided that the temperature rise does not exceed 1000 degrees $F$, the shutdown is possible by such a mechanism. Since the control rod will presumably still not cease moving out, the procedure will repeat until the 1000 degree limit has been exceeded and vaporization occurs. At this point the fuel will be rapidly expelled into the storage tank, and in the extreme the moderator will be disassembled in the same way as was discussed for the room temperature critical, except that in this case there is no question that the entire fuel region will be nearly isothermal. Of course every time the temperature rise manages to reduce $k$ to unity the power has reached a very high level so that the fuel continues to heat, expand, and recuce $\mathrm{k}$ further for a relatively long time. During this period in which the reactor is quite sub-critical, the energy developed is roughly equal to that on the rise. The fuel does not cool off, however, because there is no place for the heat to go, so that each such cycle starts at the fuel temperature produced by the previous cycle. With a $4 \%$ rod, the complete shutdown is achieved after $12 \%$ of the fuel has vaporized. The total heat generated is $4.2 \times 10^{5}$ BTU. The temperature of the fuel has now reached 2300 degrees F, so that the Inconel core shells will have melted during the vaporization. There are two effects of melting the core shells. It is reasonable to assume that the Inconel becomes mixed homogeneously with the material of the fuel. This mixing may increase $k$ again by some amount, but probably will not greatly perturb the result because the fuel is already vaporizing the reactor is disassembling rapidly. Perhaps $10 \%$ in total energy might be the order of the effect. The second result of melting the core shells is to expose the beryllium moderator to the fuel. A chemical reaction will take place which reduces $\mathrm{UF}_{4}$ of the fuel to atomic uranium and liberates $60 \mathrm{BTU}$ per pound of $\mathrm{UF}_{4}$ reacting. This energy must of course be added to the total. The principal result of the reaction, however, is to increase the local pressure in the reacting region and prevent large amounts of fuel from taking part in the reaction. There will be some additional local heating, of the same nature, caused by the increased local nuclear reactivity when fuel is mixed with beryllium. An estimate of these effects is probably another $10 \%$ in total energy. We therefore obtain a final total of about $5 \times 10^{5}$ BTU for this excursion. Oxidation of the uranium formed by reaction with beryllium is included in this figure. Since the fluoride fuel material will not oxidize significantly in air, no further heat of combustion is contributed.

For this excursion it is estimated that the heat released to the air is $2.2 \times 10^{5}$ BTU's. This corresponds to a temperature rise of 270 degrees $F$ and a pressure rise of $7.4 \mathrm{lbs} / \mathrm{sq}$ in. Of the $30 \times 10^{18}$ fission nuclei generated, about $12 \%$ reach the test cell and of these, $25 \%$ or $0.9 \times 10^{18}$ are exhausted to the atmosphere. 
b. Instantai_eo .s introuluction of $4 \%$ excess reactivity in an already critical assembly:

The same general features apply to this problem as to the corresponding case for the room temperature assembly. The main differences are that the entire fuel region must be cunsidered isothermal so that considerably more heat is required to raise it to the boiling point (even though this is lower than for metallic uranium) and that the negative temperature coefficient of reactivity reduces the effective $k$ during the rise, so that the rise is slower, and consequently the total energy developed is larger. One might wonder whether the rapidity of rise is so great that expansion of fuel into the storage tank is possible. That is, whether shocks will develop. In the present situation it is clear that shocks will not be a problem since material motions are all at a very small rate compared with sound velocity (about $10^{5} \mathrm{~cm} / \mathrm{sec}$ ). Shutdown is complete after $11 \%$ of the fuel has been vaporized. The total heat is about $5 \times 10^{5}$ BTU.

For this excursion it is estimated that about $2.4 \times 10^{5}$ BTU are released to the test cell, corresponding to a temperature rise of 290 degrees $F$ and a pressure rise of $8 \mathrm{lb} / \mathrm{sq}$ in. Of the $33 \times 10^{18}$ fission nuclei formed, $11 \%$ are transmitted to the test cell in the vapor and $26 \%$ of these nuclei (or $9 \times 1017$ ) are exhausted to the atmosphere.

\section{Damage to the Building}

The results described above for excursions resulting from various accidents indicate temperature rises up to 490 degrees $F$ and pressure rises up to $13.5 \mathrm{lb} / \mathrm{sq}$ in. With a reasonably fast relief of pressure and temperature by exhausting part of the air, the heat transfer to the cell from the air is expected to be of no great consequence. The cell structure will be strong enough to withstand the pressure rise. The major damage will result from flying pieces and contaminated material from the reactor assembly. Closing dampers and shutting off ventilating equipment should minimize spread of contamination to the rest of the bulding. 


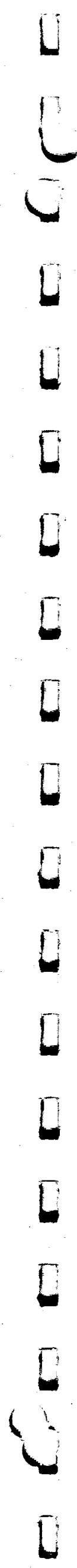


III. HAZARDS TO SURROUNDING AREA
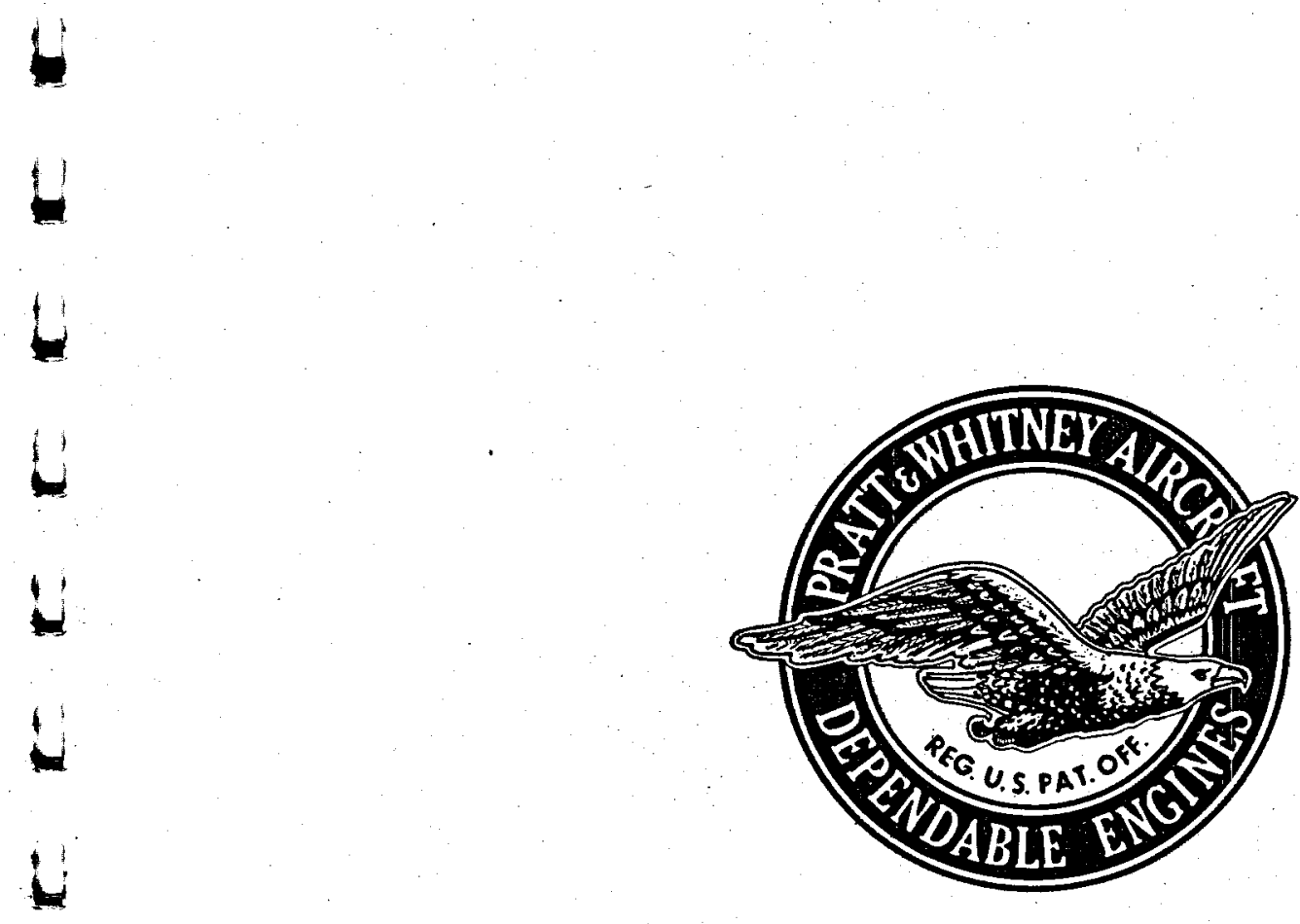

1

1

1

1

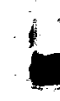

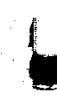

1

1

1

1 


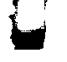

4

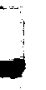

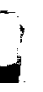

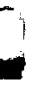

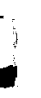

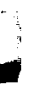




\section{A. FISSION PRODUCT RELEASE}

This chapter discusses the possible radiation hazard to both on-site and off-site personnel. The nearest on-site personnel are taken to be 1000 feet from the critical building; nearest off-site civilian houses are a little more than a half-mile distant. Meteorological parameters were suggested by D. Pack of the U.S. Weather Bureau, (Appendix D). The calculation procedures are described in Appendix B.

For the accident terminated by manual scram essentially no hazard exists. Even if a leak in the test assembly is postulated immediately after the burst and volatile fission products escape, the radiation doses would be tolerable (less than 10 rep) at distances greater than 1000 feet. In the case of other accidents, terminated by self disassembly, there are definite hazards under certain conditions although all calculated doses are less than the corresponding LD50 doses.

In calculating the radioactivity disiminated by an accident, it is assumed that the fission products which are released from the assembly mix homogeneously with the air in the test cell (volume, 64,000 cubic feet). The amount of contaminated air which is then released "instantaneously" to the atmosphere is that amount which is required to reduce the pressure within the test cell to atmospheric following the accident. Consider the accident in the cold critical assembly caused by the instantaneous insertion of $25 \%$ excess reactivity and terminated by self disassembly. During this excursion $2.8 \times 10^{5}$ BTU were generated as a result of fission, corresponding to $0.9 \times 1019$ fissions and twice as many fission product nuclei. The energy released to the air in the room is about $4 \times 10^{5}$ BTU and about $37 \%$ of the air in the room is exhausted to reduce the pressure to atmospheric. The release to the atmosphere is then $7 \times 10^{18}$ fission product nuclei. This is the most serious accident which can be conceived to occur in the subject facility in the course of the presently contemplated experimental program. 


\section{B. IRRADIATION BY A RADIOACTIVE CLOUD}

The dose resulting from irradiation due to a radioactive cloud has been calculated based on a fission product release of $7 \times 10^{18}$ active nuclei.

Table I gives the external doses to an observer on the ground downwind from the facility due to the radioactive cloud drifting past him at ground level.

\section{TABLE I}

\section{External Doses from Radioactive Cloud}

External Beta Dose (rep) Under Inversion Conditions

Distance, feet

$$
\text { LD50 }
$$

1000

2640

4000

1000

2640

4000

1000

2640

4000

1000

2640

4000
360,000
300
Wind Velocity, MPH

\begin{tabular}{|c|c|c|c|}
\hline 1 & 3 & 10 & 30 \\
\hline 490 & 550 & 735 & 805 \\
\hline 36 & 46 & 57. & 66 \\
\hline 12 & 15 & 18. & 22 \\
\hline
\end{tabular}

External Gamma Dose (r) Under Inversion Conditions

$\begin{array}{rr}17 & 20 \\ 2 & 3 \\ 1 & 1\end{array}$

25
4
2

External Beta Dose (rep) Under Lapse Conditions

$\begin{array}{lllll}360,000 & 7 & 7 & 7 & 6 \\ & 0.4 & 0.4 & 0.4 & 0.3 \\ & 0.2 & 0.2 & 0.2 & 0.1\end{array}$

External Gamma Dose ( $r$ ) Under Lapse Conditions

Table II gives inhalation doses to an observer on the ground downwind from the facility due to the radioactive cloud drifting past him at ground level.

TÁBLE II

Internal Doses from Radioactive Cloud

Dose to Thyroid (rep) under Inversion Conditions

1000

2640

4000
335

77

40
95

25

14
5

0.5

0.2
6

0.7

0.3
. 
Dose to Thyroid (rep) Under Lapse Conditions

Distance, feet

1000

2640

4000

1000

2640

4000

1000
Wind Velocity, MPH

$1 \quad 3 \quad 10 \quad 30$

$\begin{array}{rlll}12 & 4 & 1 & 0.4 \\ 2 & 0.7 & 0.2 & 0.1 \\ 1 & 0.3 & 0.1 & 0.03\end{array}$

Dose to Lung (rep) Under Inversion Conditions

$\begin{array}{rrrl}115 & 45 & 17 & 6 \\ 22 & 10 & 3 & 1 \\ 12 & 4 & 2 & 0.7\end{array}$

Dose to Lung (rep) Under Lapse Conditions

$4 \max$ 


\section{CONTAMINATION DUE TO A RAIN-OUT}

Table III gives the external gamma dose (r) due to steady light rainfall. Beta doses are assumed to be negligible because of shielding by water and earth.

\section{TABLE III}

Gamma Dose from Rain-Out

Distance, feet

Wind Velocity, MPH

\section{LD50}

1000

2640

4000
300

$1 \cdot 30$

33

30

6
3
7

3

36
8
$\times \quad 4$

30

39

8
4 


\section{CONTAMINATION DUE TO A DRY FALL-OUT}

Table IV gives the maximum external doses from fall-out, assuming release at a height of 70 feet. "Maximum". means that dose which would be received if the particles in the cloud were all of a particular size. The size has been chosen for each assumed wind velocity and distance to give the maximum dose. The accompanying table shows the particle sizes chosen as a function of wind velocity and distance. For comparison the LD50 external beta dose has been estimated to be approximately $3.6 \times 10^{5} \mathrm{rep}$ (See Appendix B). A height of release of $\mathbf{7 0}$ feet was assumed. This is considered to represent a minimum height of rise under any condition, and higher release heights would yield correspondingly smaller doses.

\section{TABLE IV}

\section{External Doses from Fall-Out}

Beta Dose (rep) Under Inversion Conditions

Distance, feet

LD50

1000

2640

4000

1000

2640

4000

1000

2640

4000

1000

2640

4000

Wind Velocity, MPH

$\begin{array}{llll}1 & 3 & 10 & 30\end{array}$

$\begin{array}{rrrrr}360,000 & 32,000 & 40,000 & 50,000 & 62,000 \\ & 2,350 & 2,800 & 3,700 & 4,600 \\ & 740 & 925 & 1,200 & 1,500\end{array}$

Gamma Dose (r) Under Inversion Conditions

$\begin{array}{rrrrr} & 230 & 265 & 350 & 380 \\ 300 & 22 & 28 & 35 & 40 \\ & 8 & 10 & 12 & 15\end{array}$

Beta Dose (rep) Under Lapse Conditions

$\begin{array}{rrrrr}360,000 & 1,000 & 1,400 & 1,800 & 2,300 \\ & 60 & 80 & 100 & 130 \\ & 18 & 23 & 31 & 38\end{array}$

Gamma Dose (r) Under Lapse Conditions

Particle Size (microns) for Maximum Fall-Out from 70 feet (particle density $2 \mathrm{gm} / \mathrm{cc}$ )

$\begin{array}{rrrrr}1000 & 25 & 39 & 80 & 120 \\ 2640 & 14 & 24 & 44 & 91 \\ 4000 & 11 & 20 & 36 & 62\end{array}$

From these numbers it appears that the maximum beta dose occurs under inversion conditions, for which it is reasonable to assume a low prevailing wind velocity (say $3 \mathrm{mph}$ ). At a half-mile distance, which is closer than the nearest dwelling, the beta dose is $0.8 \%$ of LD50 and the gamma dose is $9 \%$. Since it is known that biological reaction to radiation exposure 
decreases very rapidly with decrease in dose, these estimates do not appear particularly threatening to off-site personnel. At 1000 feet under the same weather conditions the dose increases by about a factor 10 which becomes very serious in the case of gammas. The seriousness of the results must of course be balanced against probability of occurrence which in Chapter II has been shown to be exceedingly small. An additional factor, not mentioned previously, is the ratio of cloud area to the area of a circular strip with width equal to cloud diameter. This ratio gives the probability that a certain area of ground will be subject to fall-out if meteorological conditions are such that it occurs. The value of this ratio is 0.006 at 1000 feet. The likelihood of exposure should then depend on the product of this factor, the probability that fall-out occurs, the probability that the area will be occupied, and finally the probability that the accident occurs at all. 


\section{MAKE-UP OF SURROUNDING AREA}

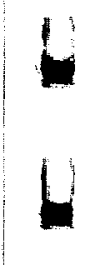

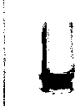

L

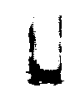

1

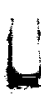

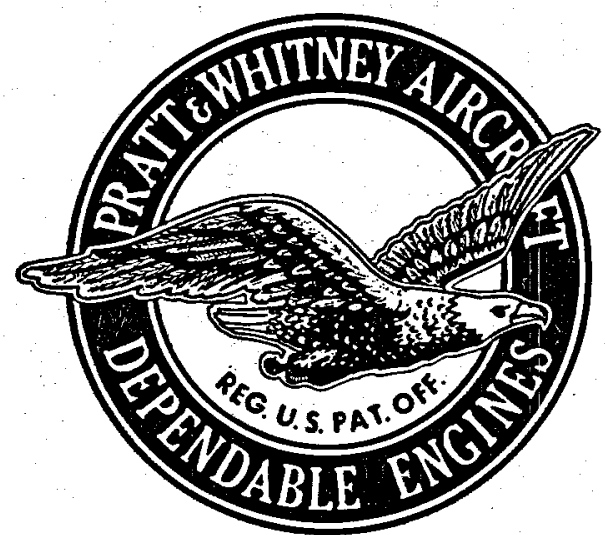

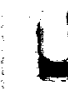

4

h

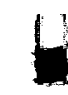

b

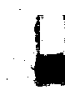

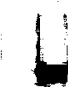

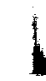




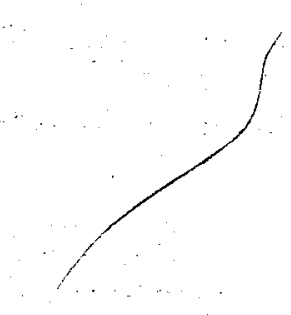

, 


\section{A. POPULATION DISTRIBUTION}

The Connecticut Aircraft Nuclear Engine Laboratory (CANEL) including the Nuclear Physics Laboratory is located on a tract of land on the west bank of the Connecticut River, approximately 18 miles south of Hartford and 5 miles southeast of Middletown. The largest community in the vicinity is Middletown with a population of 20,000 persons. The location of the site relative to adjacent communities is shown in Fig 10. The CANEL site covers 1200 acres and is roughly circular with a radius of $4000 \mathrm{ft}$. It is bounded to the North and East by the Connecticut River. The critical facility is approximately one-half mile inside this circle and 3000 feet from the nearest residence. A distance of 1000 feet separates the Nuclear Physics Laboratory from other facilities buildings on the site. The location of the Nuclear Physics Laboratory relative to the site boundaries and other facility buildings is shown in Fig 11.

The population distribution at various radii from the center of the site is given in Fig 8 . This distribution is based on the 1950 census. The major concentration of people is to the North and West of the site. There are 830 people outside the site boundaries but within a two mile radius. There are 23,290 people within a five mile radius; 66,010 within a ten mile radius; and 207,547 people within a twenty mile radius. 


\title{
CANEL FACILITY SITE PLAN
}

\author{
SITE BOUNDARY
}

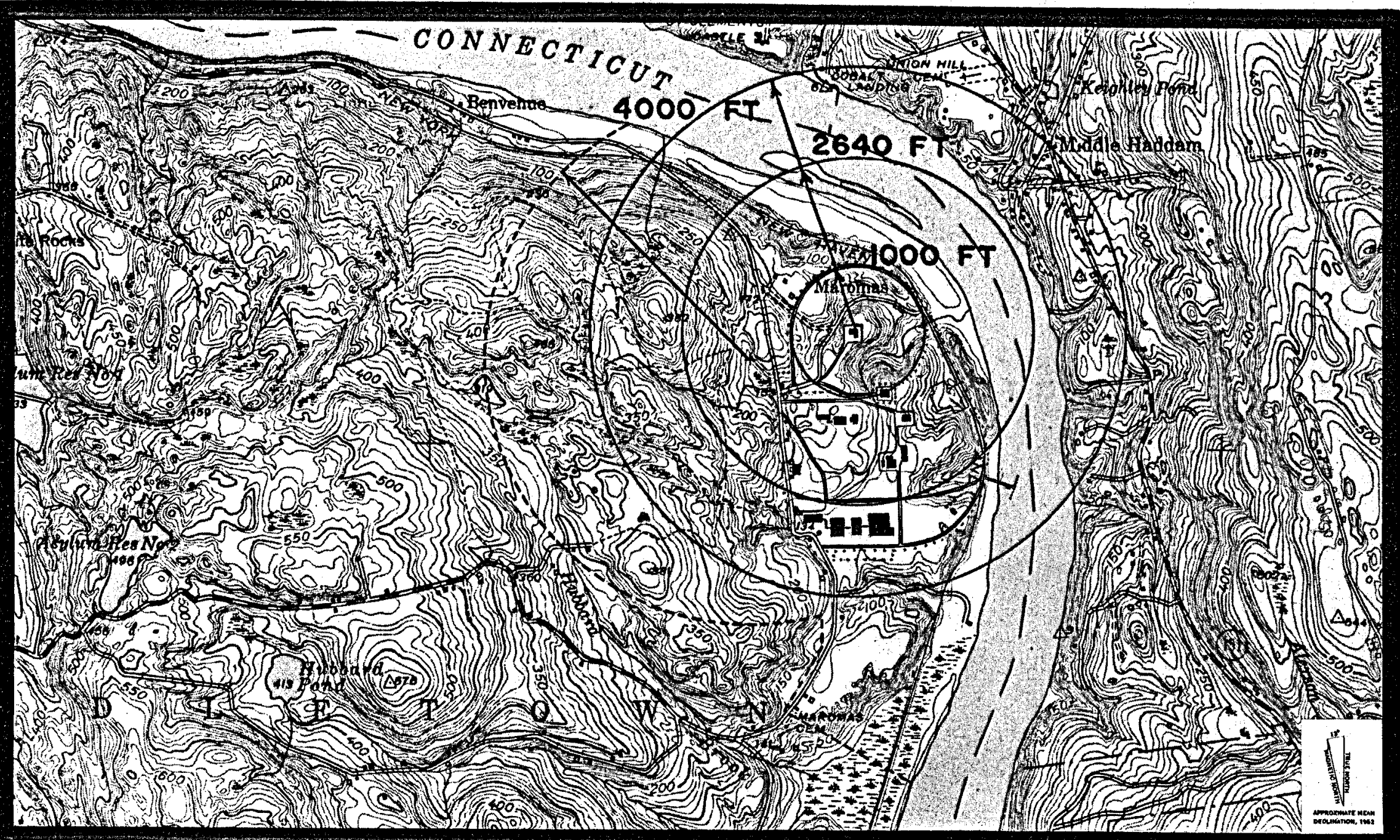

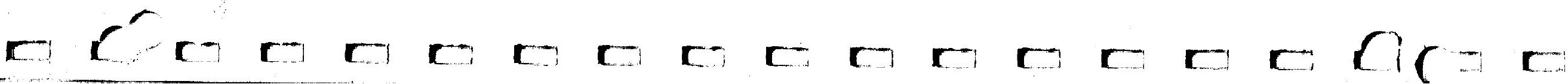




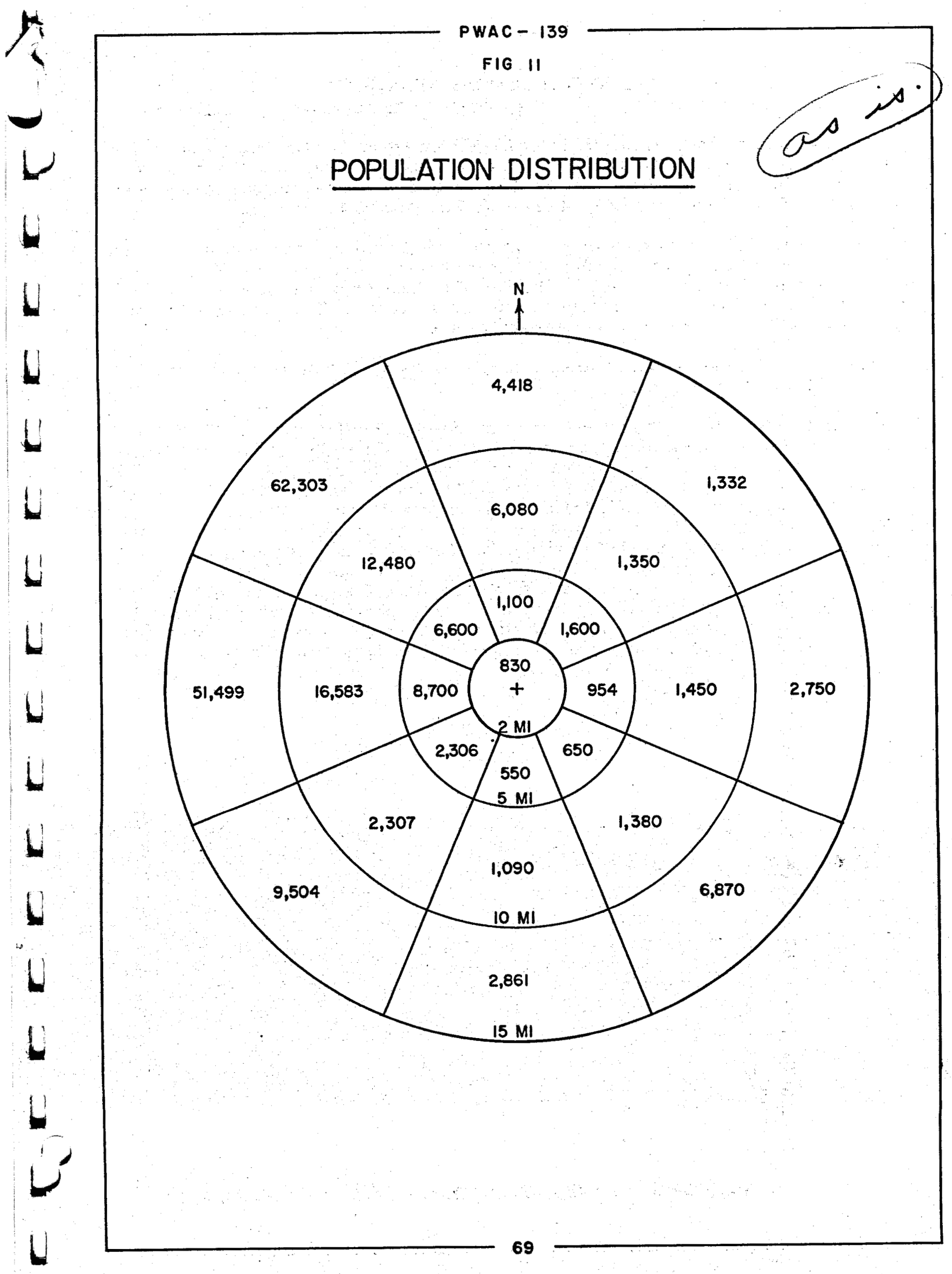




\section{B. VITAL INSTALLATIONS NEAR SITE}

The nearest vital installation to the site is the $68,500 \mathrm{KW}$ steam-electric generating station of the Hartford Electric Light Company. This represents approximately $20 \%$ of the total capacity of the Connecticut Power Company. The Hartford Electric generating station is on the Connecticut River $\mathbf{5 0 0 0}$ feet northwest of the Nuclear Physics Laboratory.

There are a number of municipal water reservoirs within 10 miles of the site. The nearest are the 5 reservoirs of the State Asylum. These are located approximately $13 / 4$ miles west of the Nuclear Physics Laboratory. The City of Middletown draws its drinking water from two reservoirs $61 / 2$ and $71 / 2$ miles west of the site center. The city of Portland has a single reservoir 5 miles north of the center of the site.

The other vital installation within 10 miles of the site is the Guided Missile Station at Portland which is 6 miles north of the site.

There are a total of 10,000 industrial workers employed by 19 different kinds of industry within a ten mile radius of the site. Tables 1 and 2 in Appendix $C$ show the detailed distribution of the workers with respect to geography and type of industry within this area. Table 3 lists the number of workers employed by each establishment. The tables show that roughly 75\% of the total number of workers listed above are employed in the Middletown-Portland area. The distribution of workers among the different kinds of industry is fairly uniform; ten industries each employ approximately 500 or more workers. The largest establishments in the area are Russell Mfg. (textiles) with 1050 workers, Robert Gaer Co. (paper), Goodyear Rubber, and Emhart-St'd Knapp Div. (machinery) each with 750 workers, and WilcoxCrittenden \& Co. (fabricated metal) and Eis Automotive Corp. (transportation equip) each with 375 workers. These establishments are all located in the Middletown-Portland region and together employ $40 \%$ of the total number of industrial workers. The remainder are employed by establishments with 150 workers or less. 


\section{RAILROAD, RIVER AND AUTOMOBILE TRAFFIC}

A single track of the New York, New Haven, and Hartford Railroad skirts the site on the north and east on the Connecticut River bank. This line is used for carrying freight only. One train per day is scheduled to travel down to Essex, Connecticut and back on this track. The railroad track is approximately 1000 feet from the Nuclear Physics Laboratory.

Approximately 1300 boats of all types pass the site per year in each direction on the Connecticut River. The boats pass at a distance approximately 2000 feet from the Nuclear Physics Laboratory.

The nearest automobile highway is Route 151 which is 3500 feet east of the Nuclear Physics Laboratory on the east bank of the Connecticut River. Heavily traveled highways in the vicinity of the site are Route $6 \mathrm{~A}$ which passes about 5000 feet north of the Laboratory and Route 9 which passes about 15,000 feet to the west. 


\section{METEOROLOGY}

Although no meteorological data exist for the proposed site itself, quite complete meteorological data have been taken for many years at Hartford, Connecticut. Although the rough terrain and close proximity of the site to Long Island Sound will influence wind patterns at the site, the major climatic features of the proposed site will be satisfactorily defined by the Hartford records.

The wind directions at the Hartford Station are almost equally divided into winds from the northerly quadrant and from the southerly quadrant. Almost half the winter time winds are from a northerly direction while in summer $45 \%$ of the wind directions are southerly. In spring and fall there is an almost equal frequency of both northerly and southerly winds. On the average winds from the easterly quadrant occur less than $10 \%$ of the time.

Except for the summer months the prevailing rain wind is north and north-northeast. During summer the most frequent rain wind will be southerly.

Over $50 \%$ of the wind speeds will be in the $4-12 \mathrm{mph}$ category with a high percentage of wind speeds less than $4 \mathrm{mph}$. Spring is the season of the strongest average winds with a mean speed of $9.4 \mathrm{mph}$ compared to the summer low of $7.0 \mathrm{mph}$. In spite of recent hurricanes the highest recorded one minute wind speed at Hartford was $70 \mathrm{mph}$.

Tornadoes are quite rare in Connecticut with only nine reported during 1916 through 1950 . Thunderstorms are fairly common in July with an average of 7 per month. Thunderstorm winds are extremely variable but a rare severe storm may cause short duration winds in excess of $50 \mathrm{mph}$.

The Hartford area receives approximately 40 inches of precipitation annually spread over an average of 127 days with a fairly uniform distribution. The snowfall averages about 40 inches per year with an inch or more of snow occurring approximately 10 days per year.

There are roughly 45 days per year during which a heavy fog occurs. Visibility is reduced to 6 miles or below approximately 30\% of the time. Although inversions form nearly every night there is nothing in the records that could be interpreted to signify that Hartford experiences an unusual amount of stable atmospheric conditions.

The narrower valley at the site and the protective surrounding terrain should result in lower average wind speeds than those reported above at Hartford. The channeling effect noted at Hartford should be even more pronounced with a large predominance of north or northwest and southerly winds. However, at night during periods of light winds the terrain will probably cause westerly drainage winds downslope from the surrounding hills and into the river valley. These air movements will be more in the nature of a drift and should rarely exceed 2 or 3 miles per hour.

It is likely that the sea breeze from Long Island will occur more frequently at the site than at Hartford. This will be almost wholly a summer phenomenon. The result of this will be (a) a change in air mass after the sea breeze arrival, (b) a high percentage of southerly winds during the afternoon, (c) less unstable lapse rate in the marine air and (d) an inversion cap on the marine air. The height of the inversion will depend largely on the vigor of the sea breeze circulation but should rise rapidly from an initial value of near 300 feet at the sea breeze arrival to near 1000 to 1500 feet during mid-afternoon. 
Another effect of the surrounding terrain will be to shield the site plateau from early morning and, particularly, late afternoon solar radiation. This will probably result in earlier formation and slightly later dissapation of the nocturnal inversion than would be experienced on a level plain in the same location.

A third difference will result from the proximity of the Connecticut River. In summer and early fall the cooler water of the river will favor early inversion formation and frequent fogs which may well deepen to encompass the site plateau. In the winter and spring the relatively warm water will lift the inversion base from the ground to 50 or 100 feet above the water and will favor earlier breakup of nocturnal inversions. 


\section{E. GEOLOGY AND HYDROLOGY}

The proposed structures at the Middletown reservation will be built on a deposit of glacial sand that forms a terrace about 140 feet high overlooking the Connecticut River. Glacial sand probably also underlies the river. Beneath the sand is a layer of dense glacial till; beneath the till is folded and recrystallized bedrock of Precambrian age.

The terrace material is permeable and its upper surface is relatively flat. It is tentatively concluded that ground water in the terrace discharges into the Connecticut River only. Therefore, a liquid spill would tend to percolate downward and thence move with ground water into the river. Conversely, any large-capacity well would withdraw ground water from most parts of the terrace and from the river.

The Connecticut River is tidal at the reservation with a maximum tidal range of about $21 / 2$ feet, which decreases with increasing river discharge. Average discharge is about 17, 300 cubic feet per second (cfs). During periods of low discharge, usually in August and September of each year, the effect of tide is sufficient to cause reversal of current. Maximum upstream current is estimated at about 1 foot per second. Maximum travel distance of upstream current is as yet unmeasured. Usual location of saline-fresh water contact is 13 to 20 miles downstream; during very low discharge saline water moves to within 10 miles of the reservation and in flood flows is completely flushed out of river.

No public water-supply in the State of Connecticut takes Connecticut River water. The river is used for commercial and pleasure boating, swimming and fishing. No private consumptive use of river water is known, but inventory is yet to be made. It is believed that no existing water well would be affected by plant operations, except, perhaps, the well of Hartford Electric Company at Benvenue. 


\section{F. SEISMOLOGY}

In order to assess the probability of occurrence of earthquakes, the earthquake history of the Middletown area was investigated. From these results, it is possible to conjecture as to the future possibility of an earthquake occurring in this region.

The State of Connecticut is reported to have had twelve earthquakes which had their epicenters within the state boundaries. Undoubtedly more shocks have occurred, but they were not recorded because of their small areal influence and low intensity. The recorded shocks had intensities that varied from 4 to 8 on the Rossi-Forel scale of intensities.

The date, location, area affected and intensity of the reported shocks is given at the end of Appendix E. From the past records it would appear that there is little danger from earthquakes. However, inasmuch as they have occurred in the past, precautions will be taken to make sure that all structures containing critical material will be constructed to withstand moderate shocks. 
v. APPENDICES

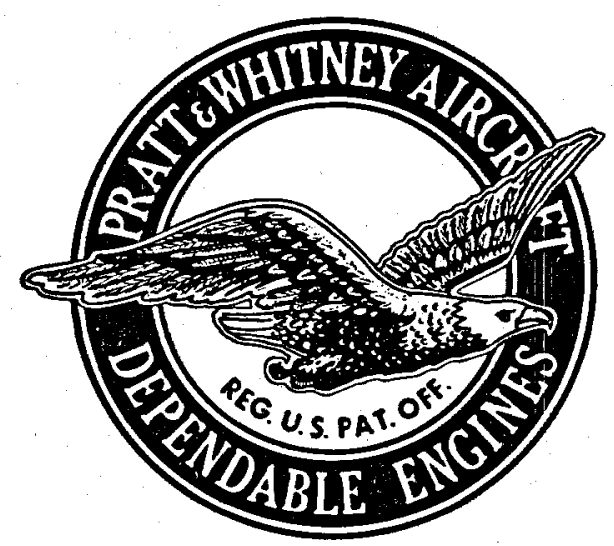


. 


\section{APPENDIX A}

\section{ANALYSIS OF ACCIDENT}

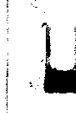

1

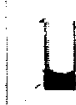

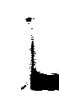

$L$

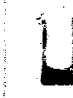

1

1

1
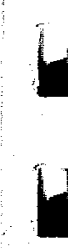

b
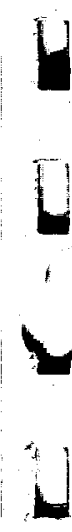


\section{A. ANALYSIS OF ACCDENT}

The first section of this appendix presents a detailed treatment of the self dissassembly of typical critical experiments after instantaneous introduction of excess reactivity. In the second section there is presented a discussion of the assumptions which have been made in the light of results obtained.

\section{Table of Numerical Data Used}

Physical Properties

$\underline{\text { Uranium Metal }}$

Density

Average Specific Heat

Melting Point

Heat of Fusion

Bolling Point

Heat of Vaporization

Heat of Oxidation

Fuel No. 30

Density

Specific Heat

Melting Point

Boiling Point

Heat of Vaporization

Telfon

Density

Specific Heat

Thermal Conductivity

Transition Temperature

Linear Expansion Coefficient

Enthalpy*

Volatilization Rate**

When Heated in Vaccuo
$18.9 \mathrm{gm} / \mathrm{cc}$

$9 \mathrm{cal} / \mathrm{mol} \mathrm{deg} \mathrm{C}$

$1133 \mathrm{deg} \mathrm{C}$

$3000 \mathrm{cal} / \mathrm{mol}$

$3900 \mathrm{deg} \mathbf{C}$

$93,000 \mathrm{cal} / \mathrm{mol}$

$300,000 \mathrm{cal} / \mathrm{mol}$
$3.2 \mathrm{gm} / \mathrm{cc}$ at $1382 \mathrm{deg} F$

$0.31 \mathrm{BTU} / \mathrm{lb} \operatorname{deg} \mathrm{F}$ (Liquid)

968 deg F

2250 deg F

$100,000 \mathrm{cal} / \mathrm{mol}$
Temperature $\operatorname{deg} \mathrm{C}$

100

200

300

340

400

440

$132 \mathrm{lb} / \mathrm{cu} \mathrm{ft}$

$0.25 \mathrm{BTU} / \mathrm{lb} \mathrm{cu} \mathrm{ft}$

$0.142 \mathrm{BTU} / \mathrm{hr} \mathrm{ft} \operatorname{deg} \mathrm{F}$

616 deg $\mathrm{F}$

See Fig 9

Absolute Joules/gm

109

225

360

455

535

595

Volatilization Rate

Temperature $\operatorname{deg} \mathrm{C}$

795

897

932

956
$\% \mathrm{Min}$

0.00152

0.118

1.264
0.490

* Preliminary data provided by T. B. Douglas of the National Bureau of Standards.

**J. Research NBS, 51, 327 (1953) 


\section{Reactor Characteristics}

\begin{tabular}{|c|c|}
\hline Mass Reactivity Coefficient & $M \frac{d k}{d M}=0.21$ \\
\hline Prompt Neutron Lifetime & $4 \times 10^{-4}$ seconds \\
\hline Inner Radius of Reflector & $33 \mathrm{~cm}$ \\
\hline Reflector Thickness & $31 \mathrm{~cm}$ \\
\hline $\begin{array}{l}\text { Prompt Temp Coefficient } \\
\text { of Reactivity (Elev Temp Ass'y) }\end{array}$ & $-2 j$ \\
\hline
\end{tabular}

In this treatment of the self disassembly problem, the following physical assumptions have been made:
a. The heat conduction of telfon is zero. (No heating of teflon takes place).
b. Volume expansion of solid or liquid uranium does not occur.
c. The core shells and moderator are not heated.
d. The heat conduction of uranium is infinite, so that at each particular instant all uranium is at the same temperature.
e. The power distribution is spatially flat across the fuel, so that all uranium is heated at the same rate.
f. The sound velocity in all materials is sufficiently high so that no shocks or rarefactions are important and the moderator may be assumed to move as $a$ rigid solid without local compression.

The amount of expansion required to reduce the reactor to subcritical after an excursion depends upon $\frac{\mathrm{dk}}{\mathrm{dr}}$. This coefficient has been derived from multigroup diffusion theory calculations of the related quantity $\frac{\mathrm{dk}}{\mathrm{k}} \div \frac{\mathrm{dv}}{\mathrm{v}}$. The corresponding value of $\frac{\mathrm{dk}}{\mathrm{dr}}$ is $-\frac{.45}{\mathrm{r}}$.

Treating the moderator-core shell assembly as an inertial mass subject to no compression, the equation of motion of the moderator is

$$
m \frac{d^{2} r}{d t^{2}}=4 \pi r^{2} p
$$

where $\mathrm{m}$ is the mass of the moderator $\left(1.5 \times 10^{6} \mathrm{gms}\right), r$ is the moderator-fuel interface radius $(33 \mathrm{~cm}$ at $t=0)$, and $p$ is the uniform pressure within the fuel at time $t$. Equation (1) may be integrated to give

$$
\frac{d r}{d t}=\frac{4 \pi}{m} \int r^{2} p d t=-\frac{r}{0.45} \frac{d k}{d t}
$$

The total change in $r$, or $k$, up to time $t$ requires one.further integration. In the case of an excursion with a hot critical assembly initiated by an instantaneous excess $k$, no reduction in $\mathbf{k}$ is assumed due to expansion of liquid fuel with temperature increase. Such an expansion would undoubtedly take place to some extent, but due to the rapid rise in temperature it is doubtful that the area available for fuel exit would be sufficient to allow the full gain implied by the temperature coefficient of reactivity. Consequently, the pessimistic assumption has been made that no such fuel expansion occurs. 
In order to evaluate the integral of equation (2), it is necessary to obtain an expression for the pressure of the fuel as a function of time. It has been assumed that no pressure or motion is developed until vaporization starts. For the cold critical experiment it is necessary to supply $0.65 \times 10^{10} \mathrm{erg} / \mathrm{gm}$ of uranium to reach 3900 degrees $C$ at which boiling begins to occur $\left(1.6 \times 10^{6} \mathrm{erg} / \mathrm{gm}\right.$ degrees C plus $5.4 \times 10^{8} \mathrm{erg} / \mathrm{gm}$ heat of fussion). There are $25 \mathrm{~kg} \mathrm{of}$ uranium, so that the energy in the uranium by the time, $t$, at which boiling commences is $1.625 \times 10^{14}$ ergs. It is assumed that no heat is transferred to the Teflon. For such an excursion in the hot critical experiment, in which the fuel is already molten with average temperature 1250 degrees F, 3.28 $\times 10^{15}$ ergs are required to bring the fuel to the boiling point (2250 degrees F). There are $1058 \mathrm{lbs}$ of fuel, and all of the fuel is assumed to be at the same instantaneous temperature.

With large excess reactivity in the reactor the effect of delayed neutrons may be neglected, so that the neutron density, $n$, follows the law

$$
\frac{d n}{d t}=\frac{k-1}{L} n \text { OR } n=n_{0}{ }^{a t}
$$

where $k$ is the reactivity, $L$ is the prompt neutron lifetime $(\mathrm{sec})$, and $a=\frac{k-1}{L} \sec ^{-1}$. The fission rate, and therefore the power, follow the same law. The power, P (ergs per sec), is then

$$
P_{.}=P_{0} \theta^{a t}
$$

If $T$ is the time at which boiling begins,

$$
\begin{aligned}
E_{T} & =\int_{0}^{T} P d t=P_{0} \int_{0}^{T} a t d t=\frac{P_{0}}{a}\left(e^{a T}-1\right) \approx \frac{P_{0} e^{a T}}{a}, \\
\text { or } \quad E_{T} & \approx \frac{P_{T}}{a} \text { defines } P_{T}, \text { since } E_{T} \text { is known. }
\end{aligned}
$$

$E_{T}$ in these equations represents the energy required to bring the material in question to the vaporization temperature. Additional energy generated in the fuel will result in the production of a gas pressure which will push the moderator radially outwards. Thus in any short time interval,

$$
d E=H d N+p d v
$$

expresses the conservation of energy. $H$ is the energy required to vaporize one gm-mole of material, $\mathrm{dN}$ is the number of moles of gas created, $\mathrm{p}$ is the pressure, and $\mathrm{dv}$ is the change in volume occupied by the gas. $\mathrm{dv}$ is taken equal to $\mathrm{dV}$, the change in volume of the core produced by radial motion of the moderator. For the cold critical it is assumed that the initial volume available to the uranium gas, the void space, is $10 \%$ of the total volume enclosed by the reflector or $1.5 \times 10^{4} \mathrm{cc}$. For the hot critical excursion, it is assumed that the gas occupies the total volume enclosed by the reflector.

Considering the vapor as a perfect gas,

$$
P V=N R \theta
$$


with $\mathrm{R}$, the gas constant equal to $8.26 \times 10^{7} \mathrm{erg} / \mathrm{deg} \mathrm{K}$-mole, and $\Theta$ the temperature, deg $\mathrm{K}$, which is constant at the boiling temperature until all of the material vaporizes. As expansion of the volume, $V$, enclosed by the reflector proceeds, the additional volume must be filled with vapor. Thus the increment in vapor volume is

$$
\begin{gathered}
d v=d v=4 \pi r^{2} d r \\
\text { and } \quad v(t)=v_{0}+\int \frac{d v}{d t} d t=v_{0}+4 \pi \int r^{2} \frac{d r}{d t} d t .
\end{gathered}
$$

Using the approximate relations

$$
d E=\frac{P(t)}{a(t)}\left(e^{a \Delta t}-1\right)
$$

and

$$
P(t+\Delta t)=P(t) e^{\Delta \Delta t}
$$

it is now possible to perform a numerical integration of the equation of motion, equation (1). $k$ is allowed to change with time according to equation (2), and $p$ is calculated from equation (8) using equation (7) and (10) to determine $N$ and $v$. In all the examples treated by this method it is assumed that the excess reactivity has been introduced instantaneously by some means, and that the only mechanism for reducing $\mathrm{k}$ is vaporization within the core leading to radial motion of the moderator. Gradual introduction of excess $k$ requires the consideration of delayed neutron periods and, in the case of the hot critical, the consideration of expansion of the liquid fuel governed by the temperature coefficient of reactivity. When these additional factors are taken into account it is seen, as described in chapter II, section C, that the resulting accidents are less serious than those originated by instantaneous introduction of reactivity. The cold critical excursions both lead to complete oxidation of the uranium fuel which is the largest part of the energy released. Oxidation of $25 \mathrm{~kg}$ of uranium generates $1.2 \times 10^{5}$ BTU which is sufficient to vaporize all of the non-gaseous uranium, but of course does not contribute fission products. The hot critical excursions develop considerably more energy because the large amount of heat required to bring the entire fuel mixture to boiling temperature results in very high power level when boiling begins. Since the fuel mixture in the hot critical does not burn, the total energy is supplied by fissions. This gives greater amounts of fission products in the fuel than in the cold critical, but only part of the fuel is vaporized. 
SAMPLE CALCULATION FOR ENERGY RELEASE IN ACCIDENT TERMINATED BY SELF-DISASSEMBLY

Instantaneous Introduction of $25 \%$ Excess Reactivity in Room Temperature Assembly

\begin{tabular}{|c|c|c|c|c|c|c|c|c|}
\hline $\begin{array}{l}t-T \\
\text { sec }\end{array}$ & $\begin{array}{l}\mathrm{E} \times 10^{-14} \\
\text { ergs } \\
\end{array}$ & $\begin{array}{c}\mathrm{N} \\
\text { moles } \\
\end{array}$ & $\begin{array}{l}\mathrm{p} \times 10^{-8} \\
\text { dynes } / \mathrm{sq} \mathrm{cm} \\
\end{array}$ & $\begin{array}{l}\mathrm{r} \times 10^{-2} \\
\mathrm{~cm} / \mathrm{sec}\end{array}$ & $\begin{array}{c}\Delta \mathrm{r} \times 10^{2} \\
\mathrm{~cm} \\
\end{array}$ & $\begin{array}{l}\text { W x 10-10 } \\
\text { work, ergs } \\
\end{array}$ & $k-1$ & $\begin{array}{c}a \\
\sec ^{-1} \\
\end{array}$ \\
\hline 0 & 1.625 & 0 & 0 & 0 & 0 & 0 & 0.25 & 625 \\
\hline $5 \times 10^{-4}$ & 2.22 & 16.1 & 3.70 & 16.9 & 84.5 & 44.6 & 0.239 & 600 \\
\hline $10 \times 10^{-4}$ & 3.00 & 37.1 & 4.75 & 39.5 & 197.5 & 322.6 & 0.214 & 535 \\
\hline $15 \times 10^{-4}$ & 3.92 & 61.1 & 3.60 & 58.7 & 293.5 & 728.6 & 0.18 & 450 \\
\hline $20 \times 10^{-4}$ & 4.90 & 86.5 & 2.66 & 75.3 & 376.5 & 954.6 & 0.14 & $\because 350$ \\
\hline $25 \times 10^{-4}$ & 5.84 & 111.5 & 1.94 & 89.8 & 449 & 1194.6 & 0.097 & 242 \\
\hline $30 \times 10^{-4}$ & 6.59 & $\left(0.49^{*}\right)$ & 3.46 & 121.6 & 608 & 1966.6 & 0.045 & 112 \\
\hline $35 \times 10^{-4}$ & 6.94 & $\left(0.24^{*}\right)$ & 3.94 & 169.6 & 848 & 3540 & -0.055 & \\
\hline
\end{tabular}

* $(2 / 3) \Delta \mathrm{E}$ for case with all fuel vaporized

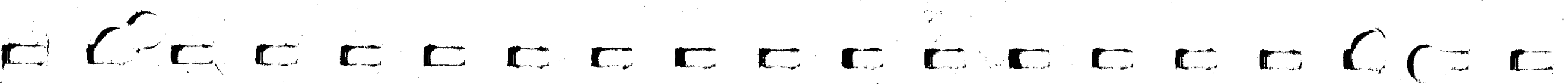




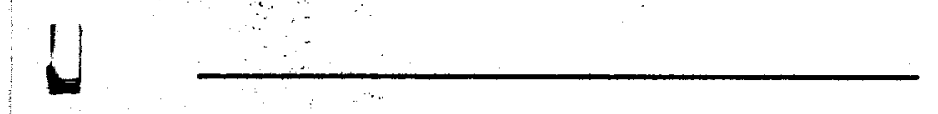

PWAC - 139

\section{APPENDIX B}

CALCULATION OF EFFECTS ON SURROUNDING AREA

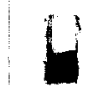

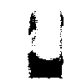

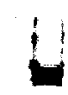

1

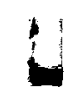

1

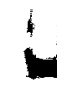

1

1

b

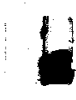

b
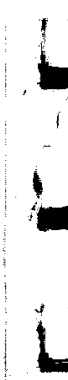


\section{A. CALCULATION OF EFFECTS ON SURROUNDING AREA}

The first section of this appendix will treat the calculations of cloud size, fall-out and dose. The second section discusses the magnitude of LD50 doses from irradiation with gammas and betas:

1. In the following table are given the values of the meteorological parameters suggested for use by D. Pack of the U. S. Weather Bureau (based on data in ORO-99). Variation of the diffusion constant, $\mathrm{C}$, with wind velocity is neglected.

$\begin{array}{ll}\frac{n}{0.2} & \text { Isotopic } C \text { (meters) } \\ 0.25 \text { (mild lapse) } & 0.28 \\ 0.33 & 0.18 \\ 0.50 \text { (strong in- } & 0.11 \\ \quad \text { version) } & 0.07\end{array}$

The cloud size at points downwind from an elevated source was calculated from the equation for an instantaneous point source (Sutton, eg 8.30),

$$
q=\frac{0}{\pi^{3 / 2} r_{0}^{3}} e^{-\left(r / r_{0}\right)^{2}}
$$

where $\mathbf{q}=$ Concentration, curies/unit volume

$\mathbf{Q}=$ total radioactivity in cloud, curies

$r=$ distance from outer of cloud

$\mathbf{r}_{0}=$ cloud radius, feet

The cloud radius is defined as

$$
r_{0}=c\left(x+x_{0}\right)^{\frac{2-n}{2}}
$$

in which $x$ = distance of cloud center from the origin, feet

$\mathbf{C}=$ Sutton's generalized diffusion parameter

$\mathbf{n}=$ Sutton's stability parameter

$x_{0}=$ a correction introduced to account for the finite initial radius of the cloud (taken as 1 foot)

For the cloud at ground level, the cloud was taken to be hemispherical having the same radius as an elevated cloud but double its concentration.

The external beta and gamma doses from a cloud passing an observer on the ground are:

$$
\begin{aligned}
& \text { Beta dose, rep }=\quad 2.13 \frac{Q}{r_{0}^{2} u} \\
& \text { Gamma dose, } r=\quad 2.13\left(\frac{Q}{r_{0}^{2} u}\right)\left(\frac{F r_{0}}{4 \lambda}\right)
\end{aligned}
$$


where $Q=$ total curies of beta or gamma activity in the cloud assuming $1 / 2$ mev per disintegration

$u=$ wind velocity, miles per hour

$r_{0}=$ cloud radius, feet

$\lambda^{\circ}=$ gamma attenuation length (200 meters)

$\mathrm{F}=$ correction term for gamma leakage as shown inKAPL-1045 Fig KH-QA 2596

The activity, $Q$, in the cloud at anytime after the burst, was calculated on the basis that the rate of beta energy production equals the rate of gamma energy production namely, $0.9 t^{-1.2} \mathrm{mev} / \mathrm{sec}$ - fission at $t$ seconds after fission for $t$ between 10 seconds and one day.

The internal dose to the lung was calculated for the case where the cloud center is at ground level and where the observer breathes at the rate of 30 liters $/ \mathrm{min}$. All fission products were assumed to be insoluble, and $12 \%$ of the inhaled activity was assumed to be retained (NBS Handbook 52). The lung mass was taken to be $1 \mathrm{~kg}$. The internal dose to the thyroid was calculated under simllar conditions. The nuclei contributing to the dose are $I^{131}$, with a yield of $3 \%$, and $I^{133}$, with a yield of $6.6 \%$. Other parameters were taken from NBS Handbook 52.

In the treatment of fall out problem it is necessary to consider that the fission products emerge as particulate matter capable of settling to the ground. It is conceivable that an excursion will vaporize most of the fuel, dirving a portion of the vapor out of the test cell. As the hot gases cool, condensation will occur and a mist or dust cloud will form. The mist or dust will be radioactive itself, and will pick up other radioactive material in the cloud. According to Perry's "Chemical Engineers' Handbook", such condensed disperlods tend to be relatively closely sized. In analyzing the radiation dose from fall-out, all the fission products are taken to occur as a cloud of condensed mist or dust. The cloud is considered to diffuse according to Sutton's equation for a point instantaneous source, but the entire cloud now has a component of velocity vertically downward (settling velocity of the particles). For a particular assumed height of emission above the ground observer (height of rise) and a particular prevailing wind velocity, there is a unique downward velocity that will cause the center of the cloud to strike the ground at any particular point. Each point downwind is therefore endangered by a particular particle size and density, since these two quantities determine the settling velocity. The dose at any point is calculated assuming that all the particles in the cloud have the size which gives the greatest dose at that particular point. The height of rise of the cloud has been taken always equal to 70 feet, which seems to be an absolute minimum for any conceivable combination of weather conditions. Fall out per unit area of ground at a point where the center of the cloud touches the ground is determined by integrating along a cloud diameter, yielding

$$
0=\frac{Q h}{\pi c^{2} x^{8-n}}
$$

where a deposited activity, curies per unit area

$Q$ total activity in the cloud when the cloud is at distance $x$ from the source

The dose from the primary betas will be very large within a few feet of the ground and will fall to a relatively small value at 15 or 20 feet above the ground. The average range for the fission product betas is about 5 feet of air. Assuming that the upwardly directed beta energy is absorbed uniformly in the first 5 feet of air above the ground (so that the total energy is deposited in a cylinder of air five feet high), the energy per gram of alr may be calculated. 
The preceding equation for deposited activity is derived from Sutton's equation for an elevated isotropic point source,

$$
X=\frac{Q}{\pi r_{0}^{2}} \exp \left(-\frac{z^{2}}{r_{0}^{2}}\right) \frac{\text { curles }-s e c}{c m^{3}}
$$

where $r_{o}^{2}=C^{2} x^{2-n}$. It is assumed that all the diffusing particles are settling uniformly with velocity $v$. The effect of this settling is to tilt the axis of the plume downward so that it intersects the ground at an angle whose tangent is $v / u$, where $u$ is the wind speed. We may approximate the elevation, $z$, of the plume at a distance, $x$, from the source by $z=h-\frac{x v}{u}$. Inserting $u=\frac{x v}{h-z}$ in the expression for the deposition, $v X$, and setting $z=0$ at the ground gives the equation quoted for deposited activity.

2. It has been shown experimentally by R. E. Zirkle that LD50 doses of beta particles, measured in gm-rep, increase linearly with body weight of the specimen. The meaning of this statement is that the effect of a dose of severity LD50 is determined by the total amount of radiation energy absorbed in the body averaged over the total mass of the body. Using Zirkle's results (National Nuclear Energy Series, McGraw Hill 1951), for a $60 \mathrm{~kg}$ man with surface area 1.6 square meters, and assuming a beta energy attenuation coefficient equal to $8.6 \mathrm{~cm}^{2} / \mathrm{gm}$, the LD50 external beta dose is $3.6 \times 10^{4}$ rep. Assuming that clothing is effective protection against the majority of fissionproduct betas, and that most of the body is protected by clothing, allows an additional factor of 10, so that the LD50 beta dose becomes $3.6 \times 10^{5}$ rep (administered externally). LD50 dose for gammas is taken as $300 \mathrm{r}$, which assumes that gamma radiation delivers a $300 \mathrm{r}$ dose to each gm of tissue in the body. 
PWAC - 139

\section{APPENDIX C}

\section{INDUSTRIES ADJACENT TO SITE}

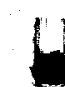

4

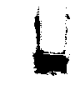

4

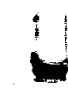

L

$\vdots$

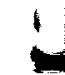

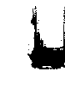

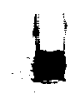

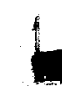

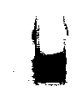

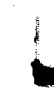

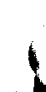




\section{A. INDUSTRIES ADJACENT TO SITE}

1. Information published in $\mathbf{1 9 5 4}$ by the Labor Department of the State of Connecticut has been used to determine the amount, kind, and distribution of industrial activity within a ten mile radius of the site. Table 1 lists the number of workers at each geographical location within this region. Table 2 gives the number of workers employed by each kind of industry found in the region. Table 3 lists the number of workers and location of each industrial establishment situated within the region. 
PWAC - 139

TABLE 1

LISTING OF LABOR MARKET AREAS (SHOWING CITIES \& TOWNS)

THAT FALL WITHIN 10 MILE RADIUS OF SITE

Local Market Area

Hartford

Middletown

Norwich

New Haven

Meriden

New Britain
Town

Rocky Hill

South Glastonbury

Hopewell

Middletown

Portland

Cromwell

East Hampton

Marlborough

Gildersleeve

Newfield

Westfield

Highland

Baileyville

Cobalt

East Meriden

Middle Haddam

Rockfall

Middlefield

Haddam Neck

Bashan

Haddam

Leesville

Higganum

Durham

Durham Center

Moodus

Ponset

Shailerville

Little Haddam

Tylerville

East Haddam

Westchester

North Westchester

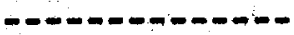

East Meriden

East Berlin
Industrial Workers

390

150

No Industry

5,975

1,925

190

820

No Industry

35

No Industry

No Industry

No Industry

No Industry

No Industry

No Industry

No Industry

30

190

No Industry

No Industry

95

No Industry

75

240

30

60

No Industry

No Industry

No Industry

No Industry

225

No Industry

No Industry

No Industry

No Industry

225 
TABLE 2

SUMMARY OF INDUSTRIAL WORKERS WTHIN 10 MILE RADIUS

OF SITE BY TYPE OF INDUSTRY AND AREA

Type of Industry

Ordnance

Food

Textiles

Apparel

Lumber \& Wood

Furniture \& Fixtures

Paper

Printing \& Publishing

Chemicals

Products of Petroleum \& Coal

Rubber

Stone, Clay \& Glass

Primary Metals

Fabricated Metals

Machinery

Electrical Equipment

Transportation Equipment

Misc. Manufacturing Industries

Auto Repair Shops

TOTALS
Middletown

Hartford

New Britain

Totals

$\begin{array}{r}150 \\ 70 \\ 1,465 \\ 495 \\ 40 \\ 70 \\ 855 \\ 240 \\ 195 \\ 30 \\ 960 \\ 205 \\ 240 \\ 1,365 \\ 1,215 \\ 450 \\ 870 \\ 845 \\ 130 \\ \hline \\ \hline\end{array}$

9,890

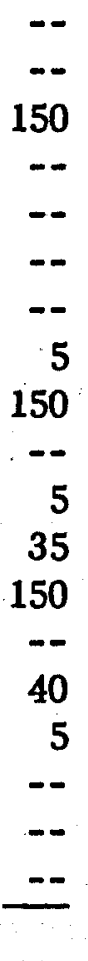

540

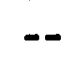

$-\infty$

$-$

$-$

5

$-$

$-$

$--$

150

$--$

$--$

35

5

5

30

$--$

$-$

$--$

$\overline{--}$

230
150

70

1,615

495

45

70

855

245

495

30

965

275

395

1,370

1,285

455

870

845

130

GRAND

TOTAL $\quad 10,660$ 


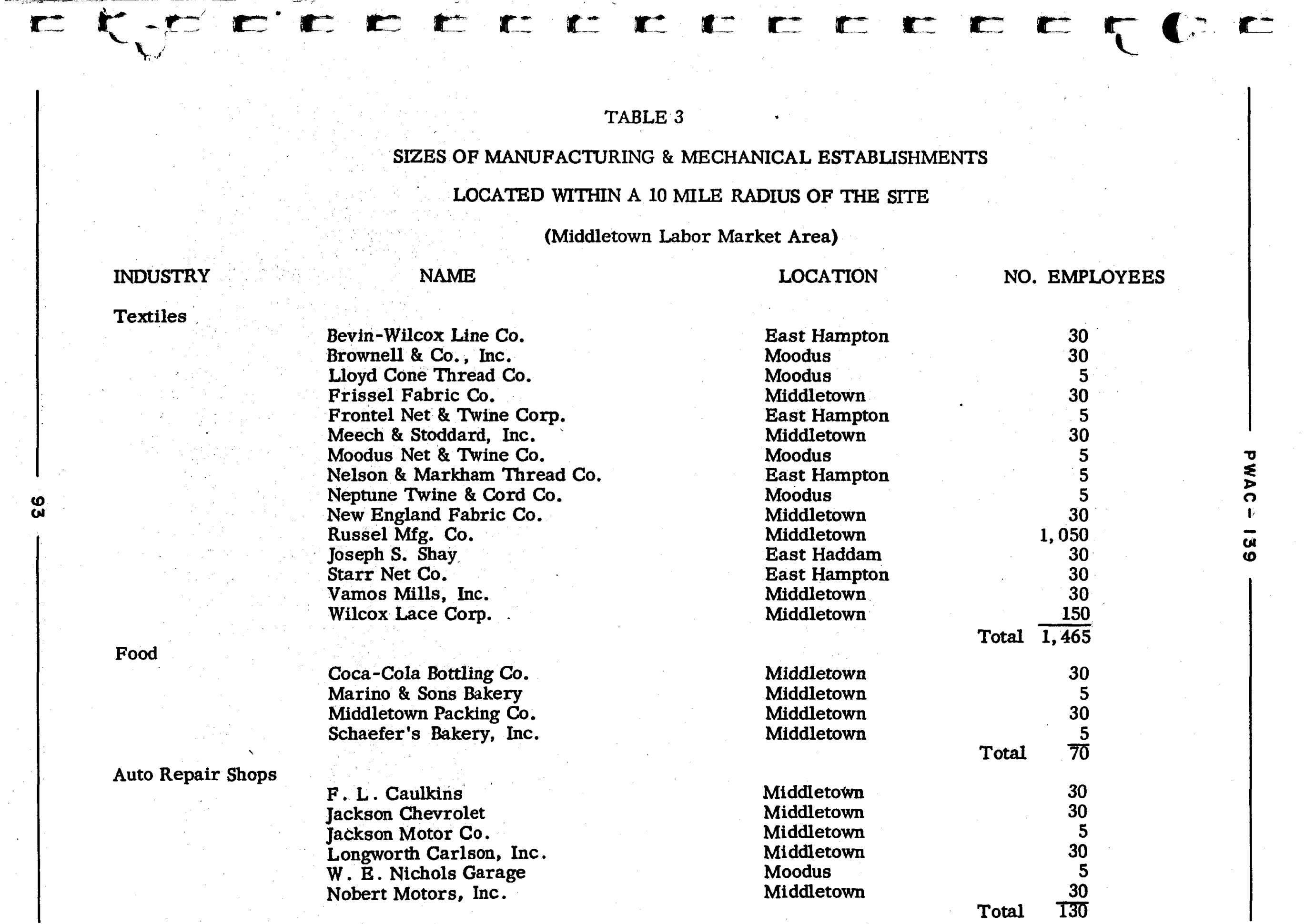




\section{INDUSTRY}

NAME

Machinery

J. C. Barton Co.

Clark Harrow Co.

Cromwell Mach. Corp.

DuMond Gun Co.

Emhart-St'd Knapp Div.

C. G. Garrigus Co :

L. M. Gowin Mfg. Co.

C. L. Jarvis Co.

Johnson Mfg. Co.

Machine Design Shop

Materials Mfg. Corp.

Middlesex Eng. \& Mfg. Co.

Middletown Grinding Service

Modern Mech . \& Scientific Lab

Parker Bailey Mfg. Co.

L. L. Sweet

Electrical Equipment

Electroweave Mfg. Co.

Haddam Mfg. Co.

The Newton Co.

Raymond Eng. Lab.

Ripley Co., Inc.

Sturrup, Inc.

Viking Instrument, Inc.

Transportation Equipment
Alcap Mfg. Co., Inc.
Eis Automotive Corp.
Hetrick Mfg. Co.
Holter's Yacht Yard
Mastercraft Trailer
Portland Boat Works
Safeway Heat Elements.
United Aircraft Corp.

\section{LOCATION}

East Hampton

Higganum

Cromwell

East Hampton

Portland

Haddam

Middletown

Middletown

Middletown

Moodus

Middletown

Middlefield

Middletown

Higganum

Cromwell

Durham Center

Haddam

Haddam

Middletown

Middletown

Middletown

Middletown

East Haddam

Middletown

Middletown

Gildersleeve

Portland

Middletown

Portland

Middletown

Portland
NO. EMPLOYEES

$\begin{array}{r}30 \\ 5 \\ 30 \\ 5 \\ 750 \\ 5 \\ 30 \\ 150 \\ 5 \\ 5 \\ 150 \\ 5 \\ 5 \\ 5 \\ 5 \\ 30 \\ \hline 215\end{array}$

Total $\overline{1,215}$

30

30

30

150

30

30

150

Total $\quad 450$

30

375

5

150

5

150

150

Total $\overline{870}$

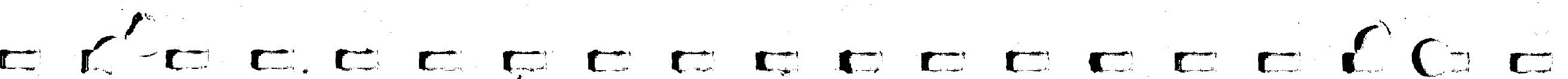


Fabricated Metal

Chemicals
Auto Heat Corp.

Auto Machine Products

Artistic Wire Products

Jultus Carlson

Clairglow Mfg. Co.

Durham Mfg. Co.

E. Hampton Finishing Co.

Eastern Wire Products

Econo Products Co.

Hillside WIdg. \& Ornamental Works

N. E. House Co.

Johnson Electroplating Co.

Liteway Mfg. Corp.

Lord \& Hodge

Merriam Mfg. Co.

Middletown Brass Co.

Middletown Mfg. Co.

Middletown Wire Products

Mohawk Mfg. Co.

Organic Fini shing Co.

J. A. Otterbein

Prime Sheet Metal Co.

Rayco Products, Inc.

Robot Auto Heat Corp.

D. \& H. Scovil, Inc.

O. A. Smith Mfg. Co.

United Specialists Corp.

Wilcox, Crittenden \& Co.

American Distilling Co.

Dulite Chemical Corp.

Rogers \& Hubbard Co.

Synorganic Products, Inc.

Worth Spar Co., Inc.
LOCATION

NO. EMPLOYEES

Middletown

Middletown

East Hampton

Middletown

Portland

Durham

East Hampton

Middletown

East Haddam

Middletown

Middletown

East Hampton

Middletown

Middletown

Durham

Middletown

Middletown

Middletown

Middletown

Middletown

Middletown

Middletown

Middletown

Middletown

Higganum

Middlefield

Haddam

Middletown

East Hampton

Middletown

Portland

Portland

Middletown
30

5

150

5

30

30

5

5

5

5

30

5

150

30

30

150

30

5

150

5
5

30

30

30

30

375

Total 1,365

5

30

150

5 
TABLE 3 (CONTINUED)

INDUSTRY

Lumber \& Wood

Wilber Ehlers

General Woodworking Co.

J. T. Rossi

Rubber

Airex, Inc.

Goodyear Rubber Co.

Middletown Rubber Corp.

O.M.O. Mfg. Co.

Stone, Clay and Glass

Auburn Mfg. Co.

Carwin House, Inc.

Conn. Asbestos Products

Cromwell Concrete Products

Eureka Mica Mining Co.

MacDonnell Brick Co.

Middlesex Septic Tank Co.

Primary Metals

Bevin Bros. Mfg. Co.

W. H. Chapman Co.

H. R. Eng. Lab.

Starr Bros. Bell Co.

Misc. Manufacturing Industries

A. Brozek Co.

Frizmar, Inc.

Gong Bell Mfg. Co.

N. H. Hill Brass Co.

Middlesex Silver Co.

Philson Industries

Remington Rand

Rogers Mfg. Co.

J. E. Stevens Co.

\section{LOCATION}

NO. EMPLOYEES

Portland

East Hampton

Middletown

Gildersleeve

Middletown

Middletown

Middletown

Middletown

East Haddam

Middletown

Cromwell

Portland

Middletown

Portland

East Hampton

Middletown

East Haddam

East Hampton

Moodus

Higganum

East Hampton

East Hampton

Middletown

Middletown

Middletown

Rockfall

Cromwell
5

5

30

Total $\quad 40$

30

750

150

30

+. 150

5

5

5

30

Total $\frac{5}{205}$

150

30

30

30

Total $\frac{30}{240}$

5
30
150
150
150
30
150
30
Total $\quad \frac{150}{845}$
Total 960 
TABLE 3 (CONTINUED)

INDUSTRY

NAME

Products of Petroleium \& Coal

Anderson Oil Co.

Ordnance

Lyman Gunsight Corp.

$\varphi$
LOCATION

Portland

Middlefield
NO. EMPLOYEES

Total $\quad \frac{30}{30}$

Total $\quad \frac{150}{150}$ 


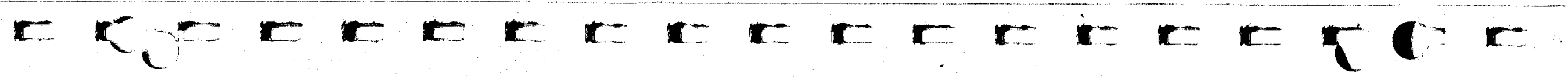

TABLE 3 (CONTINUED)

(Hartford Labor Market Area)

INDUSTRY

NAME

LOCATION

NO. EMPLOYEES

Textiles

Matson Mill, Inc.

So. Glastonbury

150

Printing \& Publishing

Stecher Traung Lith. Corp.

Rocky Hill

Chemicals

Hartford Rayon Corp.

Rocky Hill

150

Rubber

O.K. Rubber Welders

Rocky Hill

Stone, Clay \& Glass

Elmore Co.

Rocky Hill Vault Co.

Rocky Hill

Rocky Hill

30
Total $\quad \begin{array}{r}5 \\ \hline 5\end{array}$

Primary Metals

Conn. Foundry Co.

Rocky Hill

150

Machinery

C.S.W. Plastic Types, Inc. Guite Tool \& Engraving Co. Saber Exper. Tool Co.

Rocky Hill

Rocky Hill

Rocky Hill

\begin{tabular}{r}
30 \\
5 \\
Total $\quad 5$ \\
\cline { 2 - 2 }
\end{tabular}

Electrical Equipment

Advanced Electronics, Inc.

Rocky Hill

Total $\frac{5}{540}$ 
(New Britain Labor Market Area)

INDUSTRY

Lumber \& Wood

Chemicals

Stone, Clay \& Glass

\section{Eastern Brick Co.}

Primary Metals

$\bar{\circ}$

Fabricated Metals

Machinery
NAME

Aldon's Woodworking

Stanley Chemical Co.

New Britain Die Cast Corp.

Precision Processing Co.

Kelsey Mfg. Co.
LOCATION

East Berlin

East Berlin

East Berlin

East Berlin

East Berlin

East Berlin
NO. EMPLOYEES

5

150

30

5

5

30

Total

225 
APPENDIX D

METEOROLOGY FOR THE

NUCLEAR PHYSICS LABORATORY

AT CANEL

\section{PREPARED BY}

SCIENTIFIC SERVICES DIVISION

\section{U. S. WEATHER BUREAU}

WASHINGTON, D. C.

SEPTEMBER， 1955 


\section{A. INTRODUCTION}

1. This site is located on the west bank of the Connecticut River approximately 5 miles east-southeast of Middletown, Connecticut and 20 miles south-southeast of Hartford, Connecticut. Long Island Sound is approximately 20 miles due south of the site. The facility site proper is on a small relatively flat plateau approximately 100 feet above the river level. This plateau is surrounded by rough, hilly terrain with the tops of the larger hills three to four hundred feet above the plateau level. 


\section{B. SOURCE OF DATA}

1. Although no meteorological data exist for the proposed site itself, quite complete meteorological data have been taken for many years at Hartford, Connecticut. Although the rough terrain and close proximity of the site to Long Island Sound will influence wind patterns at the site (estimated differences will be discussed later), the major climatic features of the proposed site may be satisfactorily defined by the Hartford records. Attached to this report is a copy of the Local Climatological Data for Hartford Connecticut. The narrative summary included in that publication presents a good general description of the weather of this area. The table headed "Normals, Means, and Extremes" on page 2 of this summary presents average data on temperature, degree days, precipitation, etc. 


\section{CLIMATOLOGICAL REVIEW}

1. In the present brief report, the meteorological parameters which directly influence the diffusion of material by the atmosphere will be stressed.

Surface wind direction - the hourly observations for a 5 year period, 1934-1938, for the Weather Bureau Airport Station at Hartford (Brainard and Rentschler Fields) were studied in detail. Table I presents the percentage frequency of the wind direction. The term "prevailing direction" does not strictly apply to this location since the wind directions are almost equally divided into winds from the northerly quadrant (90 degree arc from northwest through north-northeast) and from the southerly quadrant (90 degree arc from south-southeast through southwest). There is however a definite seasonal shift with almost half the winter time winds blowing down valley from a northerly direction, while in summer $45 \%$ of the wind directions are southerly. In spring and fall there is an almost equal frequency of both northerly and southerly winds. The channeling of winds is particularly evident in the very low frequency of east winds. On the average winds from the easterly quadrant occur less than $10 \%$ of the time.

It is necessary to examine the wind structure during periods of precipitation in order to consider the effect of washout of material from the atmosphere. Table I also presents the frequency of wind directions at Hartford during those hours when precipitation was falling. (This was approximately 12\% of the time). Except for the summer months the prevailing rain wind is north and north-northeast. During summer, and associated with showers or thunderstorms, the most frequent rain wind will be southerly.

Wind direction may also be important when the atmosphere is very stable and diffusion is a minimum. Although no direct correlation of temperature gradient and wind direction are available it seems likely that light north or south winds will occur with the usual nocturnal non-persistant inversion but that for persistant (ie more than one day) inversions the wind direction is likely to be east and southeast.

Special mention should be made of the conditions brought about by the occurrence of the summer sea breeze. Prior to the on-set of the sea breeze the temperature gradient over the land will usually be quite unstable due to solar heating. The cooler marine air moving inland will be less unstable and at the boundary of the marine air an inversion will be formed. Thus the sea breeze will tend to scour out and push ahead any contaminants previously in the air, or to contain within the marine air (depth from 200 to $\mathbf{1 5 0 0}$ feet) contaminants released after arrival of the sea breeze. Further study, at the site, is required to accurately evaluate the action of the sea breeze in dispersing airborne materials.

\section{a. Surface Wind Speed}

Table II presents the percentage frequency of wind speeds in various class intervals. The distribution of speeds is remarkably constant with season. Over $50 \%$ of the wind speeds will be in the 4-12 mph category. Also of note is the high percentage of low wind speeds (less than $4 \mathrm{mph}$ ). In the summer more than $30 \%$ of the wind speeds are in this category, dropping off to only $19 \%$ in the spring. Spring is also the season of the strongest average winds with a mean speed of $9.4 \mathrm{mph}$ compared to the summer low of $7.0 \mathrm{mph}$. During a 38 year period of record wind speeds have reached $50 \mathrm{mph}$ or higher in all but 4 months of the year. In spite of recent hurricanes the highest recorded one minute wind speed at Hartford occured in November 1950 with a wind of $70 \mathrm{mph}$. However, winds of higher speeds, approaching $100 \mathrm{mph}$ are not improbable. 

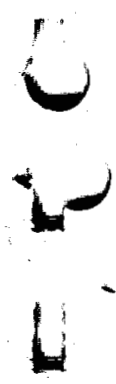

1

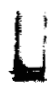

1

1

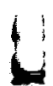

1

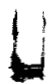

4
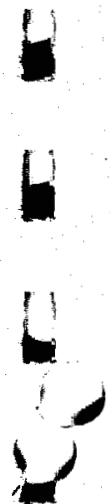

c. Atmospheric Stability

Measurements of vertical temperature gradient distribution have not been made in the Hartford area. However, measurements made at other locations show that a) low level inversions are characteristic of the night hours and b) there is a high correlation between low wind periods, restricted visibility and the occurrence of inversions. Conversely high wind speeds and good visibility are indicative of "lapse" conditions and rapid diffusion by the atmosphere. The Hartford area experiences approximately 45 days per year when heavy fog occurs. Visibility is reduced to 6 miles or below approximately 30 per cent of the time, on an annual basis.

Obviously not every occurrence of a stable lapse rate will be accompanied by lowered visibility. Although inversions form nearly every night there is nothing in the records that could be interpreted to signify that Hartford experiences an unusual amount of stable atmospheric conditions. 


\section{ESTIMATED METEOROLOGICAL DIFFERENCES BETWEEN}

\section{HARTFORD AND PROPOSED SITE}

1. Meteorological conditions at the proposed site will differ somewhat in two categories, wind flow and diurnal distribution of stability.

The narrower valley at the site and the protective surrounding terrain should result in lower average wind speeds. The channeling effect noted at Hartford should be even more pronounced with a large predominance of north or northwest and southerly winds. However, at night during periods of light winds the terrain will probably cause westerly drainage winds downslope from the surrounding hills and into the river valley. These air movements will be more in the nature of a drift and should rarely exceed 2 or 3 miles per hour.

It is likely that the sea breeze from Long Island Sound will occur more frequently at the site than at Hartford. This will be almost wholly a summer phenomenon. The result of this will be; a) a change in air mass after the sea breeze arrival, b) a high percentage of southerly winds during the afternoon, c) less unstable lapse rate in the marine air and d) an inversion cap on the marine air. The height of the inversion will depend largely on the vigor of the sea breeze circulation but should rise rapidly from an initial value of near 300 feet at the sea breeze arrival to near 1000 to, 1500 feet during mid-afternoon.

A quantitative description of the frequency, duration and structure of the sea breeze must await the results of the micrometeorological survey of the site. As a corollary to the day time sea breeze will be the lighter drainage return flow at night. In terrain of this type it is expected the drainage flow will closely follow the Connecticut River channel.

Another effect of the surrounding terrain will be to shield the site plateau from early morning and, particularly, - late afternoon solar radiation. This will probably result in earlier formation and slightly later dissapation of the nocturnal inversion than would be experienced on a level plain in the same location.

A third difference will result from the proximity of the Connecticut River. In summer and early fall the cooler water of the river will favor early inversion formation and frequent fogs which may well deepen to encompass the site plateau. In the winter and spring the relatively warm water will lift the inversion base, from the ground, to 50 or 100 feet above the water and will favor earlier breakup of nocturnal inversions.

All of the preceding qualitative statements are relatively minor fluctuations on the more general pattern determined from the long period Hartford records and these fluctuations will affect primarily the site itself and seldom extend their influence more than a few miles.

U. S. Weather Bureau

Washington, D. C. September, 1955 


\section{$r r_{i}$}

Percentage Frequency of Wind Direction, Weather Bureau Airport Station, Hartford, Connecticut

(Based on hourly observations 1934 through 1938)

Winter Spring Summer Fall Annual
(All obs.) Pummer (1949-1954) $^{\text {*Night }} \quad \underset{\text { (1949-1954) }}{\text { Annual (duration precipitation) }}$

$\begin{array}{lrr}\text { N } & 12 & 10 \\ \text { NNE } & 10 & 10 \\ \text { NE } & 3 & 6 \\ \text { FNE } & 1 & 2 \\ \text { E } & 1 & 2 \\ \text { ESE } & 1 & 2 \\ \text { SE } & 3 & 5 \\ \text { SSE } & 4 & 6 \\ \text { S } & 10 & 12 \\ \text { SSW } & 7 & 8 \\ \text { SW } & 7 & 5 \\ \text { WSW } & 3 & 2 \\ \text { W } & 5 & 4 \\ \text { WNW } & 5 & 4 \\ \text { NW } & 13 & 10 \\ \text { NNW } & 12 & 9 \\ & & \end{array}$

$\begin{array}{rrr}7 & 10 & 10 \\ 7 & 9 & 9 \\ 5 & 5 & 5 \\ 1 & 2 & 1 \\ 1 & 1 & 1 \\ 1 & 1 & 1 \\ 5 & 4 & 4 \\ 8 & 6 & 6 \\ 15 & 13 & 13 \\ 12 & 9 & 9 \\ 10 & 8 & 8 \\ 3 & 2 & 2 \\ 4 & 4 & 4 \\ 3 & 3 & 4 \\ 8 & 8 & 9 \\ 6 & 8 & 9 \\ 4 & 7 & 4\end{array}$

8
9
6
2
2
2
5
7
9
11
10
4
4
4
9
7

6
6
4
1
1
1
5
9
20
12
9
2
3
2
6
6

16

Calm 3

3

"Day 8 a.m. -5 p.m.

Night 5 p.m. -7 a.m. 


\section{TABLE II}

Percentage Frequency of Wind Speed Groups (mph), Weather Bureau Airport Station, Hartford, Connecticut (Based on hourly observations 1934 through 1938)

Wind $\because$

Speed

Winter

Spring

Summer

Fall

Annual

(All obs.)

Annual (during precipitation)

Group

$3 \%$
16
24
29
21
6
1
$*$
$*$

$4 \%$

27

1-3 mph

18

4-7

24

8-12

29

13-18

19

19-24

25-31

$32-46$

46

Mean Wind

Speed (mph) 9.2

9.4

7.0

7.5

$5 \%$

21

26

27

16.

4

$\begin{array}{lll}1 & 2 & 4 \\ * & * & 1 \\ * & * & *\end{array}$

*Less than $1 \%$

$26 \quad 27$

(1949-1954)

$2 \%$

16

61

19

*

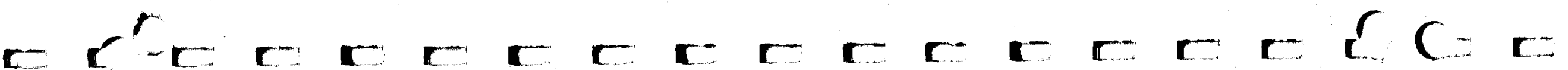




\section{U. S. DEPARTMENT OF COMMERCE \\ WEATHER BUREAU}

LOCAL CLIMATOLOGICAL DATA

\section{WITH COMPARATIVE ḊATA}

HART FORD, CONHECTICUT

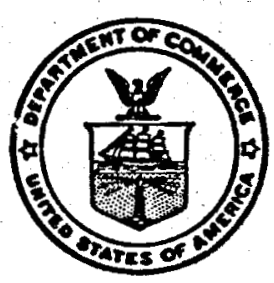

SARRATIVE CLIHATOLOGTCAL SUMARY

Bradley Field 1s lockted about 3 miles west of the Connectlcut River on silght rise in gxound in a broad portion of the Connectlout River valley between NorthSouth nountaln renges whose helghts do not exceed 1200 feet.

The stations latitude $\left(41^{\circ} 36^{\circ}, \mathrm{x}\right)$ pleces tt well Inside the northern temperature climatic zone in prevalling vest to east morement of air carrying the majority of wenther srs tems into Connectlcut from the west. The average vinter-time position of the "polar Front" boundary between cold dry polax a1r and varm nolst tropleal, is just south of We fogland, which belps to expletn the extensive vinter storm ectivity and day to day veriability

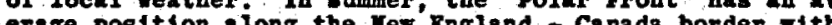
this station in a warm and pleasant atmosptere.

The locution of Hartford, relative to continent and ocean 18 also sgriflcant. Rapld veather changes result when torms move northward along the rid-Atiantic coast, lrequent1y producing etrong and persistent north-east inds assoctated with storos known locally as cosstals or northess ters. Soxsonally, weather characteristics vary from the cold and dry continental-polar arr of finter to the warm, maritime air of summer, the one from Canada, the other from the cult of lexico, Caribbean sea or Atthe other from summer thunderstorins develop in the Berksbire Mounting to the west and corthwest, nove orer the Connecticut Valley and then accompanied by wind and hail, somet ines ceuse considerable damage to crops, particulerly tobacco. During the vinter, rain often falls tbrough cold alr trapped in the valley, creating extremely hazardous 1 ce conditions. On clear nights in the late summex or eariy cutum, cool a1r drainage 1nto the velley and noisture from the Connecticut River produce team and/or ground from the Connecticut River produce nteam and/or ground hampering ground and als transportation.

Hean nontbly temperatures range from 26 degrees 10 late January and early Tebruary to 75 degrees in July, Absolute extremes are 101 degrees, September, 1953 and -24 degreez, Yebruary, 1943. The everage dally temperature variation is 18 degrees ith the greatest in mid-mpring and aldautumn. The mean date of the last killing frost is April 19th. And the 11rst, October 17th. The mean length of the groming seasor is 181 days; the shortest being 130 days $1 n 1917$ and the longest 214 days 101920 . The prevaling wind direction for e1x nonths, Apri1-Septenber 1. southerly but becomes north or northwesterly for the months October through larch. The average annual precipitation is 40.48 inches; the rettest month being september, 1938 with 14.58 inches ead the driest, October, September, 1938 with 14.69 


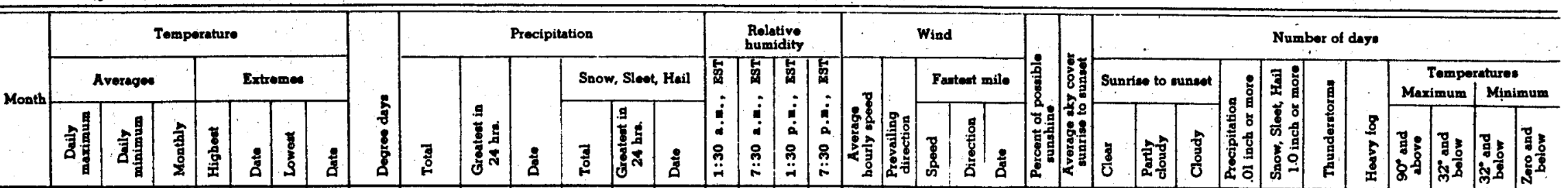

Sap.

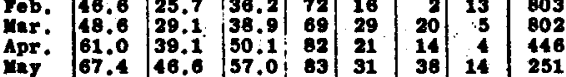

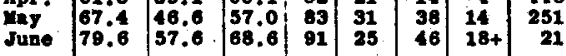

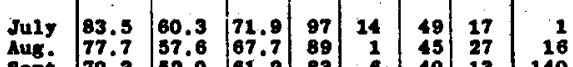

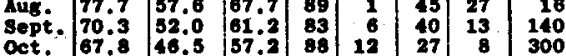

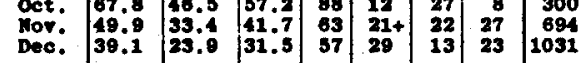

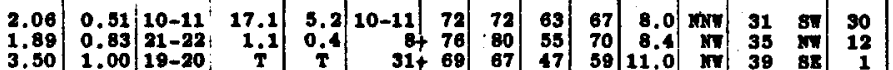

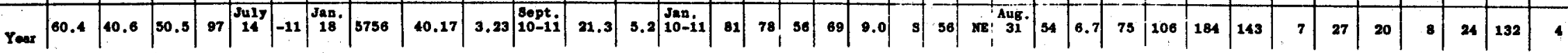
Data for current joar fros January 1 through July 31 are for fartford (Brainard rield); date shown sor balance of the year are for Hartford (Bradley rield).

NORMALS, MEANS, AND EXTREMES
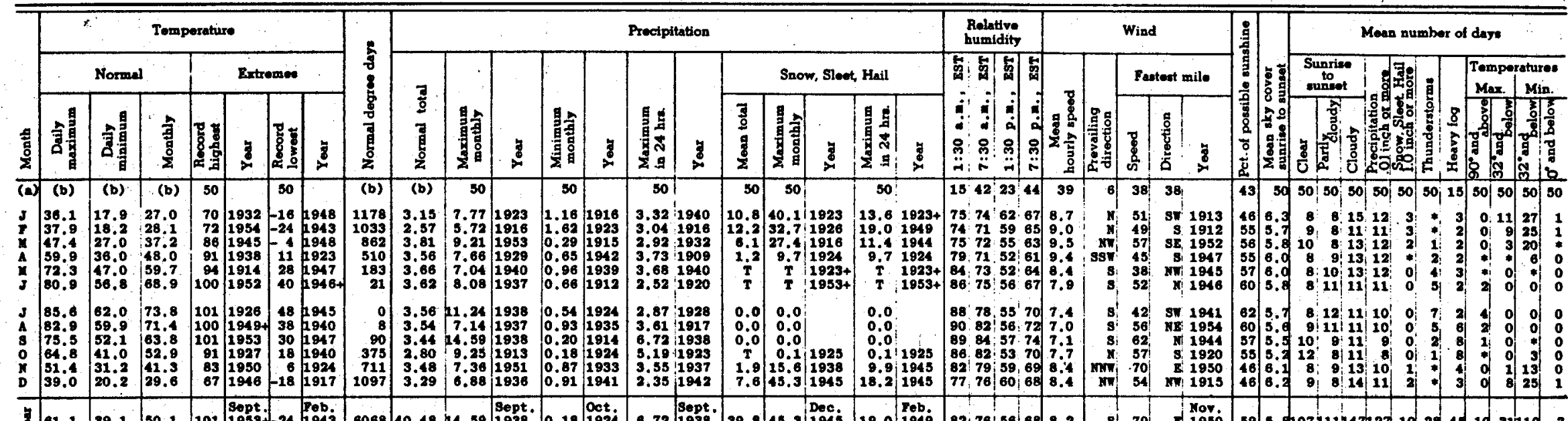

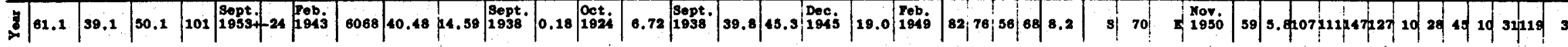

(i)

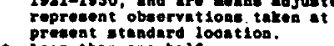

:

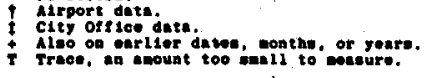

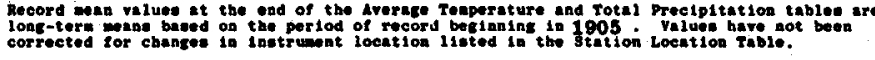

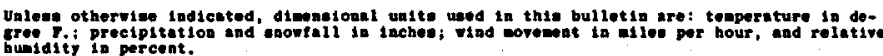

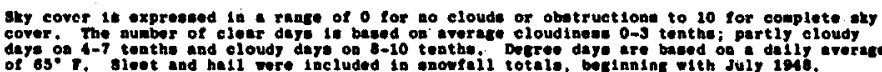

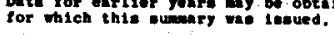

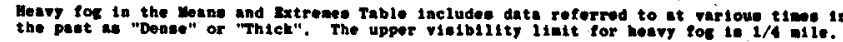

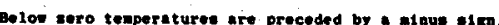

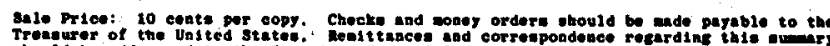

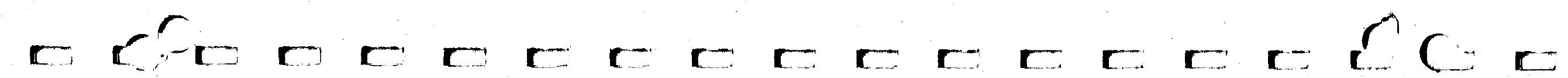




\section{AVERAGE TEMPERATURE}

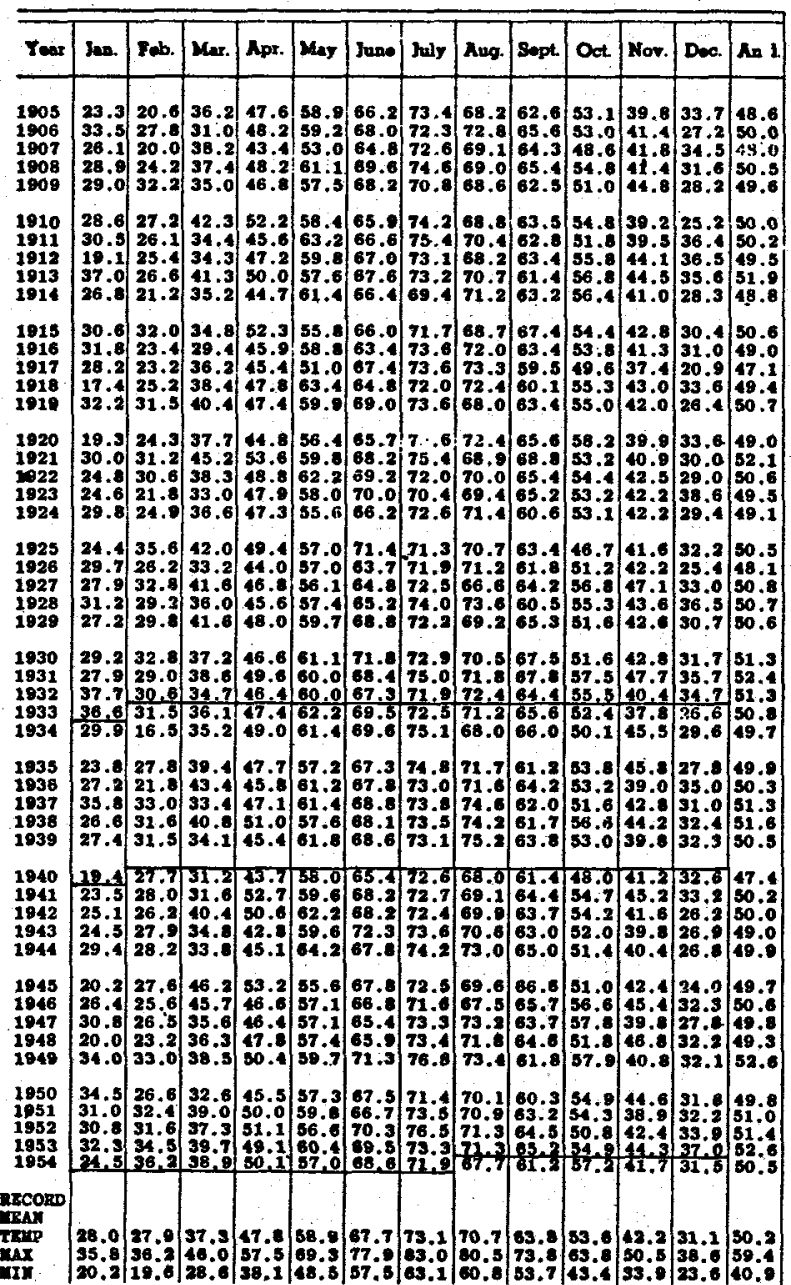

TOTAL PRECIPITATION

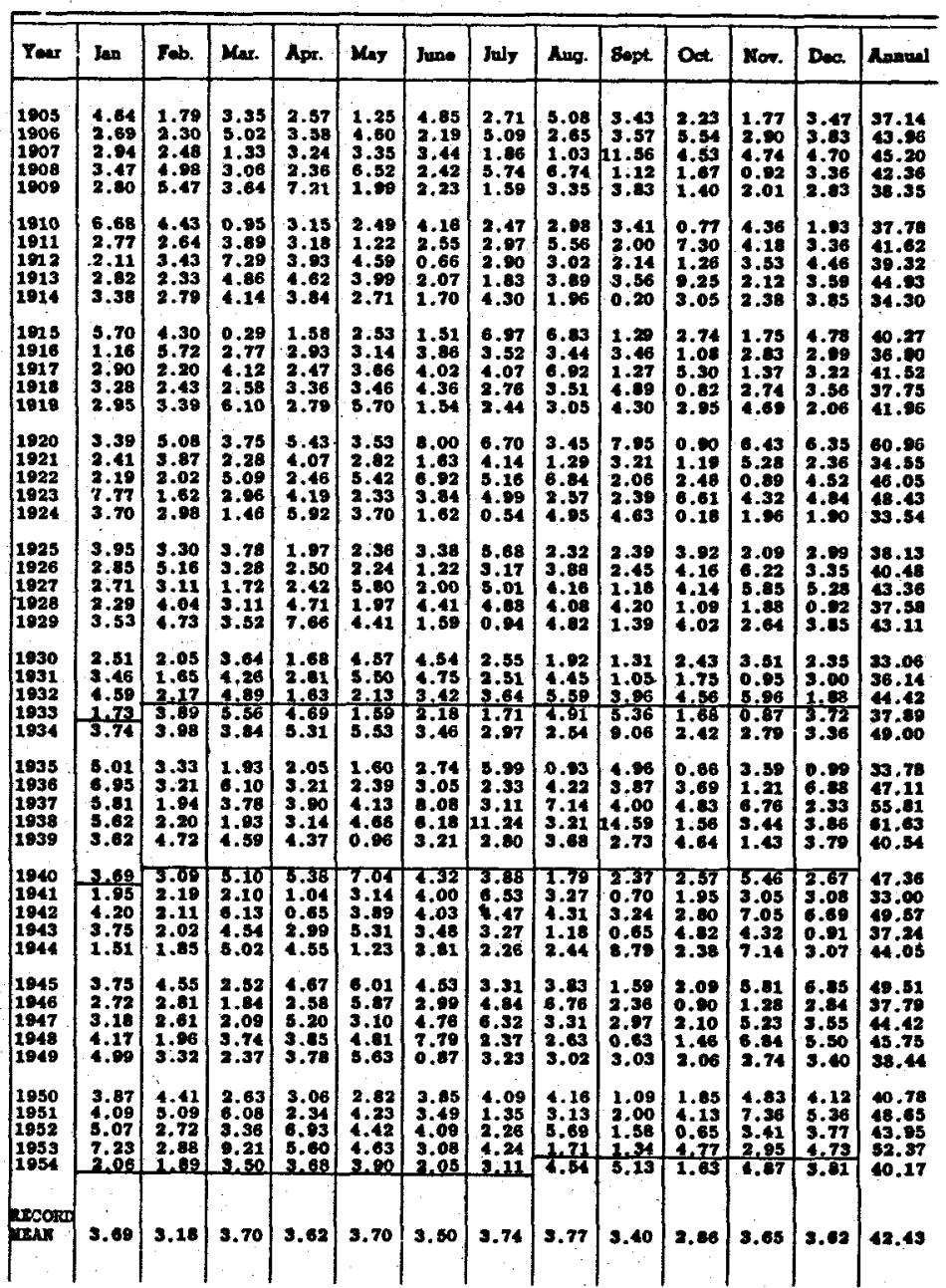

MONTHIY AND SEASONAL DEGREE DAYS

\begin{tabular}{|c|c|c|c|c|c|c|c|c|c|c|c|c|c|}
\hline Soavon & suly & Angi. & Sept & ox & Nor. & $D$ & Jan. & Tab. & Mar. & Apr. & $M_{0 y}$ & Juno & Total \\
\hline $\begin{array}{l}1905 \\
1905-06 \\
1906-07 \\
1907-08 \\
1908-09\end{array}$ & $:$ & $\begin{array}{l}4 \\
1 \\
34 \\
34\end{array}$ & 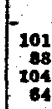 & $\begin{array}{l}372 \\
378 \\
506 \\
320 \\
320\end{array}$ & $\begin{array}{l}739 \\
705 \\
608 \\
710\end{array}$ & {$\left[\begin{array}{l}970 \\
2173\end{array}\right.$} & $\begin{array}{l}2297 \\
080 \\
2204 \\
1118 \\
11115\end{array}$ & $\begin{array}{l}2240 \\
1043 \\
2233 \\
1187 \\
018\end{array}$ & $\begin{array}{l}893 \\
2051 \\
633 \\
855 \\
025\end{array}$ & $\mid \begin{array}{l}522 \\
305 \\
619 \\
315 \\
313 \\
314\end{array}$ & $\begin{array}{l}211 \\
237 \\
377 \\
180 \\
241\end{array}$ & $\begin{array}{r}67 \\
30 \\
118 \\
18 \\
81\end{array}$ & $\begin{array}{l}6092 \\
6092 \\
6779 \\
8143 \\
8061\end{array}$ \\
\hline $\begin{array}{l}1900-10 \\
1910-11 \\
1911-12 \\
1912-13 \\
1913-14\end{array}$ & 3 & $\begin{array}{r}82 \\
7 \\
23 \\
35 \\
4\end{array}$ & $\begin{array}{l}105 \\
225 \\
125 \\
133 \\
148\end{array}$ & $\begin{array}{l}136 \\
333 \\
110 \\
287 \\
271\end{array}$ & $\mid \begin{array}{l}608 \\
776 \\
763 \\
629 \\
613\end{array}$ & $\begin{array}{l}\text { H141 } \\
238 \\
887 \\
882 \\
814\end{array}$ & & $\begin{array}{l}2037 \\
2092 \\
2117 \\
11081 \\
1228\end{array}$ & $\mid \begin{array}{l}705 \\
947 \\
953 \\
732 \\
926 \\
926\end{array}$ & $\mid \begin{array}{l}281 \\
584 \\
595 \\
456 \\
812\end{array}$ & $\mid \begin{array}{l}216 \\
129 \\
179 \\
246 \\
172\end{array}$ & $\begin{array}{l}91 \\
41 \\
64 \\
35 \\
49\end{array}$ & $\begin{array}{l}6900 \\
6305 \\
63008 \\
63586 \\
63118\end{array}$ \\
\hline $\begin{array}{l}1914-19 \\
1915-18 \\
1916-17 \\
1917-18 \\
1918-19\end{array}$ & $\begin{array}{r}23 \\
2 \\
4\end{array}$ & $\begin{array}{r}38 \\
13 \\
0 \\
8\end{array}$ & $\begin{array}{l}148 \\
97 \\
106 \\
176 \\
170\end{array}$ & $\begin{array}{l}279 \\
328 \\
337 \\
477 \\
305\end{array}$ & $\begin{array}{l}710 \\
664 \\
709 \\
829 \\
682\end{array}$ & $\begin{array}{l}1138 \\
1074 \\
1052 \\
1367 \\
9073\end{array}$ & $\begin{array}{l}1064 \\
1032 \\
1139 \\
11773 \\
1017\end{array}$ & 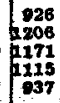 & $\mid \begin{array}{l}939 \\
1105 \\
694 \\
621 \\
760\end{array}$ & $\mid \begin{array}{l}380 \\
575 \\
589 \\
514 \\
529\end{array}$ & $\begin{array}{l}287 \\
203 \\
436 \\
205 \\
288\end{array}$ & $\begin{array}{l}43 \\
23 \\
24 \\
64 \\
36\end{array}$ & $\begin{array}{l}5960 \\
8809 \\
8494 \\
86936 \\
8592\end{array}$ \\
\hline $\begin{array}{l}1919-20 \\
1920-21 \\
1921-22 \\
1922-23 \\
1923-24\end{array}$ & : & $\begin{array}{l}25 \\
10 \\
10 \\
16\end{array}$ & $\begin{array}{l}99 \\
99 \\
58 \\
78 \\
78 \\
79\end{array}$ & $\begin{array}{l}331 \\
221 \\
364 \\
335 \\
366\end{array}$ & $\begin{array}{l}991 \\
753 \\
732 \\
673 \\
685\end{array}$ & $\begin{array}{r}1196 \\
979 \\
2084 \\
113 \\
819\end{array}$ & $\begin{array}{l}2415 \\
1085 \\
1243 \\
1243 \\
12583\end{array}$ & 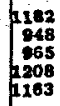 & $\mid \begin{array}{l}843 \\
815 \\
830 \\
889 \\
879\end{array}$ & $\begin{array}{l}\mathbf{6 0 5} \\
350 \\
501 \\
521 \\
534\end{array}$ & $\begin{array}{l}274 \\
109 \\
120 \\
227 \\
289\end{array}$ & $\begin{array}{l}83 \\
28 \\
11 \\
27 \\
57\end{array}$ & 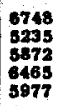 \\
\hline $\begin{array}{l}1924-25 \\
1925-26 \\
1926-27 \\
1927-28 \\
1928-29\end{array}$ & $\begin{array}{l}0 \\
1 \\
5\end{array}$ & $\begin{array}{r}25 \\
12 \\
34 \\
2\end{array}$ & \begin{tabular}{|l}
169 \\
123 \\
219 \\
69 \\
164
\end{tabular} & $\begin{array}{l}375 \\
365 \\
436 \\
295 \\
328\end{array}$ & $\begin{array}{l}681 \\
701 \\
687 \\
539 \\
641\end{array}$ & $\begin{array}{l}2098 \\
10018 \\
1227 \\
9927 \\
9829\end{array}$ & $\begin{array}{l}2253 \\
095 \\
2152 \\
2152 \\
1045 \\
1174\end{array}$ & $\begin{array}{l}828 \\
2087 \\
0822 \\
0042 \\
0886\end{array}$ & $\left|\begin{array}{l}713 \\
983 \\
727 \\
903 \\
723\end{array}\right|$ & $\left|\begin{array}{l}471 \\
628 \\
349 \\
383 \\
520\end{array}\right|$ & $\left|\begin{array}{l}250 \\
251 \\
277 \\
238 \\
221\end{array}\right|$ & $\begin{array}{l}14 \\
96 \\
62 \\
65 \\
31\end{array}$ & \begin{tabular}{|l}
5857 \\
5657 \\
6155 \\
3811 \\
3602
\end{tabular} \\
\hline
\end{tabular}

\begin{tabular}{|c|c|c|c|c|c|c|c|c|c|c|c|c|c|c|}
\hline Soason & fouly & A ug. & Sopt. & ott & Nor. & Doc & c. & & ab. $\mid M$ & Mar. & Apr. & $\mathbf{m a y}_{\mathbf{y}}$ & Jane & Total \\
\hline $\begin{array}{l}1929-30 \\
1980-31 \\
1931-32 \\
1932-33 \\
1933-34\end{array}$ & ? & $\begin{array}{r}12 \\
13 \\
4\end{array}$ & $\begin{array}{r}96 \\
62 \\
55 \\
101 \\
70\end{array}$ & \begin{tabular}{|l|}
416 \\
416 \\
230 \\
304 \\
388 \\
\end{tabular} & \begin{tabular}{|l}
677 \\
663 \\
820 \\
741 \\
819
\end{tabular} & $\begin{array}{l}206 \\
1033 \\
911 \\
940 \\
1195\end{array}$ & $\begin{array}{l}4 \\
511 \\
5 \\
1 \\
0 \\
5 \\
5 \\
5\end{array}$ & 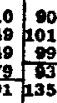 & \begin{tabular}{l|l}
100 & 8 \\
10 & 8 \\
96 & 8 \\
358 & 8 \\
58 &
\end{tabular} & $\begin{array}{l}862 \\
817 \\
838 \\
825 \\
9025\end{array}$ & $\begin{array}{l}548 \\
463 \\
558 \\
3524 \\
182\end{array}$ & \begin{tabular}{|l|}
188 \\
205 \\
100 \\
128 \\
157 \\
\end{tabular} & $\begin{array}{l}5 \\
28 \\
53 \\
50 \\
25\end{array}$ & $\begin{array}{l}5883 \\
8841 \\
83524 \\
3502 \\
6520\end{array}$ \\
\hline $\begin{array}{l}1934-33 \\
1935-36 \\
1936-37 \\
1937-38 \\
1938-39\end{array}$ & $:$ & $\begin{array}{l}34 \\
11 \\
\text { i1 } \\
0\end{array}$ & $\mid \begin{array}{l}38 \\
127 \\
200 \\
184 \\
126\end{array}$ & $\mid \begin{array}{l}260 \\
346 \\
371 \\
629 \\
271\end{array}$ & $\begin{array}{l}587 \\
373 \\
784 \\
666 \\
628\end{array}$ & $\begin{array}{l}1097 \\
151 \\
1028 \\
1050 \\
1013\end{array}$ & 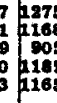 & 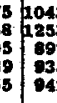 & \begin{tabular}{l|l}
43 & 7 \\
53 & 6 \\
38 & 6 \\
382 & $?$ \\
442 &
\end{tabular} & $\begin{array}{c}793 \\
686 \\
980 \\
748 \\
938\end{array}$ & $\begin{array}{l}825 \\
381 \\
383 \\
436 \\
636\end{array}$ & $\begin{array}{l}280 \\
158 \\
141 \\
237 \\
174\end{array}$ & $\begin{array}{l}43 \\
16 \\
20 \\
10\end{array}$ & $\begin{array}{l}6168 \\
6051 \\
3663 \\
3878 \\
5886\end{array}$ \\
\hline $\begin{array}{l}1939-40 \\
1940-41 \\
1941-42 \\
1942-43 \\
1943-14\end{array}$ & 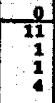 & $\begin{array}{l}20 \\
20\end{array}$ & \begin{tabular}{|l|}
96 \\
140 \\
104 \\
110 \\
129
\end{tabular} & $\begin{array}{l}387 \\
325 \\
343 \\
334 \\
105\end{array}$ & $\begin{array}{l}760 \\
712 \\
896 \\
703 \\
756\end{array}$ & i & & 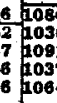 & 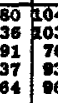 & 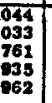 & \begin{tabular}{|l|}
338 \\
378 \\
433 \\
665 \\
398
\end{tabular} & \begin{tabular}{|l|}
221 \\
129 \\
120 \\
194 \\
26
\end{tabular} & $\begin{array}{l}77 \\
75 \\
34 \\
22 \\
44\end{array}$ & $\begin{array}{l}6733 \\
6425 \\
5732 \\
6477 \\
6945\end{array}$ \\
\hline $\begin{array}{l}1944-45 \\
1945-46 \\
1940-17 \\
1947-16 \\
1948-49\end{array}$ & 8 & $\begin{array}{r}22 \\
24 \\
28 \\
1 \\
7\end{array}$ & $\begin{array}{r}97 \\
77 \\
62 \\
158 \\
90\end{array}$ & $\mid \begin{array}{l}\mathbf{4 3 0} \\
\mathbf{3 s 2} \\
278 \\
238 \\
414\end{array}$ & $\begin{array}{l}741 \\
678 \\
587 \\
758 \\
347\end{array}$ & & 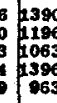 & 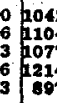 & \begin{tabular}{l|l}
62 & 5 \\
04 & 5 \\
77 & 9 \\
14 & 9 \\
97 & 9
\end{tabular} & $\begin{array}{c}589 \\
589 \\
909 \\
9290 \\
625\end{array}$ & $\begin{array}{l}357 \\
549 \\
557 \\
5515 \\
145\end{array}$ & $\begin{array}{l}293 \\
292 \\
273 \\
293 \\
193\end{array}$ & $\begin{array}{l}35 \\
74 \\
72 \\
37 \\
20\end{array}$ & \begin{tabular}{|l}
6231 \\
6970 \\
6971 \\
6012 \\
6653 \\
5420
\end{tabular} \\
\hline $\begin{array}{l}1949-50 \\
1950-51 \\
1951-52 \\
1952-33 \\
1953-54\end{array}$ & : & $\begin{array}{r}8 \\
2 \\
3 \\
7 \\
10 \\
\end{array}$ & \begin{tabular}{|c|}
2392 \\
183 \\
101 \\
73 \\
99 \\
\end{tabular} & $\begin{array}{l}257 \\
315 \\
331 \\
132 \\
309 \\
\end{array}$ & \begin{tabular}{|l}
728 \\
607 \\
775 \\
671 \\
616 \\
\end{tabular} & $\begin{array}{l}1020 \\
1022 \\
1005 \\
935 \\
862 \\
862\end{array}$ & 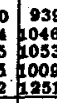 & 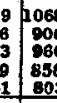 & \begin{tabular}{l|l}
68 & 9 \\
06 & 8 \\
60 & 8 \\
50 & 7 \\
03 & 8 \\
\end{tabular} & $\begin{array}{l}898 \\
891 \\
854 \\
7776 \\
8709\end{array}$ & $\begin{array}{l}375 \\
441 \\
412 \\
678 \\
416 \\
\end{array}$ & $\begin{array}{l}236 \\
179 \\
256 \\
164 \\
251 \\
\end{array}$ & $\begin{array}{r}48 \\
34 \\
7 \\
21 \\
\end{array}$ & \begin{tabular}{|l}
5006 \\
5361 \\
5759 \\
5438 \\
5470 \\
5470
\end{tabular} \\
\hline $4-68$ & & & 160 & 001 & 694 & 11031 & & & & & & & & \\
\hline
\end{tabular}


MONTHLY AND SEASONAL SNOWFALL

\begin{tabular}{|c|c|c|c|c|c|c|c|c|c|c|c|c|c|}
\hline Saleson & Soly & Aus. & sope | & $\infty$ & Nor. & Des. & Jen. & Fob. & Mar. & $A_{p r .}$ & $M_{0}$, & Juso & Toles \\
\hline 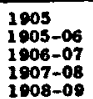 & 0 & $\begin{array}{l}0 \\
\vdots \\
\vdots \\
0\end{array}$ & $\begin{array}{l}0 \\
\vdots \\
\vdots \\
0\end{array}$ & $\begin{array}{l}0 \\
\vdots \\
0 \\
1\end{array}$ & & & & & $\mid$\begin{tabular}{|cc}
0.94 \\
25.8 \\
5.86 \\
2.8 \\
8.6
\end{tabular} & $\left|\begin{array}{l}0.1 \\
0.8 \\
0.8 \\
0.8 \\
0.7\end{array}\right|$ & $\mid \begin{array}{l}\tau \\
0 \\
T \\
0 \\
0 \\
\end{array}$ & : & $\begin{array}{l}0.5 \\
0.8 \\
8.3 \\
1.3\end{array}$ \\
\hline & & $\begin{array}{l}0 \\
\vdots \\
\vdots\end{array}$ & $\begin{array}{l}0 \\
: \\
0 \\
0\end{array}$ & $\begin{array}{l}0 \\
\vdots \\
\vdots \\
\vdots \\
\tau\end{array}$ & \begin{tabular}{|l|l}
1.8 \\
3.3 \\
10.1 \\
0.5 \\
0.7
\end{tabular} & & & $\begin{array}{l}12.2 \\
14.6\end{array}$ & $\begin{array}{rl}0.2 & 0.2 \\
0.80 \\
20.8 \\
2.1 \\
3.0\end{array}$ & $\left|\begin{array}{c}0.2 \\
\hdashline \\
i t \\
T \\
T \\
T\end{array}\right|$ & $\mid \begin{array}{l}0 \\
0 \\
0 \\
0 \\
0\end{array}$ & : & $\begin{array}{l}46.8 \\
435.8 \\
30.8 \\
19.8 \\
61.8\end{array}$ \\
\hline & $\begin{array}{l}: \\
\vdots \\
\vdots \\
0\end{array}$ & $\begin{array}{l}\vdots \\
\vdots \\
\vdots\end{array}$ & $:$ & $\begin{array}{l}\tau \\
\tau \\
\vdots \\
0\end{array}$ & $\begin{array}{c}4.5 \\
T \\
0.8 \\
0.4 \\
T\end{array}$ & & 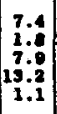 & $\because 8$ & $\begin{array}{r}1.0 \\
27: 0 \\
7.2 \\
7.0 \\
3.0\end{array}$ & $\mid$\begin{tabular}{r|}
7.3 \\
3.3 \\
0.4 \\
4.5 \\
$i$
\end{tabular} & $\mid \begin{array}{l}0 \\
0 \\
T \\
0 \\
0 \\
0\end{array}$ & : & $\begin{array}{l}25.8 \\
77.1 \\
35.5 \\
34.8 \\
17.2 \\
17.2\end{array}$ \\
\hline 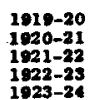 & & $:$ & $:$ & $\begin{array}{l}0 \\
\vdots \\
\vdots \\
0 \\
0\end{array}$ & $\mid \begin{array}{c}T \\
T \\
T \\
0.5 \\
T\end{array}$ & & & $\begin{array}{l}24.6 \\
21.2\end{array}$ & $\begin{array}{r}20.0 \\
5.0 \\
5.8 \\
3.8 \\
4.2\end{array}$ & $\left|\begin{array}{l}0.1 \\
1 \\
0.7 \\
0.72 \\
0.7\end{array}\right|$ & $\begin{array}{l}0 \\
\vdots \\
0 \\
0 \\
0 \\
0\end{array}$ & : & $\begin{array}{l}53.3 \\
52.8 \\
26.5 \\
627.6 \\
27.7\end{array}$ \\
\hline 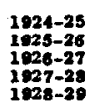 & $\begin{array}{l}0 \\
\vdots \\
\vdots \\
0\end{array}$ & $\begin{array}{l}0 \\
: \\
: \\
0\end{array}$ & $:$ & $\begin{array}{c}0 \\
0.2 \\
\dot{t} \\
0 \\
\dot{T}\end{array}$ & $\left|\begin{array}{c}0.0 \\
\vdots \\
\vdots \\
i \\
i\end{array}\right|$ & $\mid \begin{array}{c}0.1 \\
30 . \\
20 \\
0 \\
0.4\end{array}$ & & $\mid$\begin{tabular}{|l}
0.1 \\
32.7
\end{tabular} & $\begin{array}{l}0.2 \\
: .0 \\
7.1 \\
7.8 \\
3.0\end{array}$ & $\left|\begin{array}{c}T \\
0.1 \\
T \\
T \\
1.0\end{array}\right|$ & $\begin{array}{l}0 \\
\vdots \\
\vdots \\
0\end{array}$ & $\therefore$ & $\begin{array}{l}19.0 \\
7.0 .7 \\
74.1 \\
20.5 \\
26.8\end{array}$ \\
\hline
\end{tabular}

\begin{tabular}{|c|c|c|c|c|c|c|c|c|c|c|c|c|c|}
\hline Solex & Jaly & Aug. & Sopt & ot & Nor. & Dec. & lose & Tab. & jers. & Apr. & Mus & Junos & I \\
\hline & & : & 0 & & $\tau$ & & & & 8.0 & $\tau$ & $:$ & $:$ & \\
\hline $\begin{array}{l}8-33 \\
\text {-3-34 }\end{array}$ & $\begin{array}{l}0 \\
0 \\
0 \\
0\end{array}$ & & 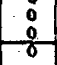 & & \begin{tabular}{|l|} 
\\
\\
\end{tabular} & & & & & $0^{\circ}$ & $:$ & & 83.3 \\
\hline $\begin{array}{l}4-35 \\
5-36\end{array}$ & : & $:$ & $\begin{array}{l}0 \\
0 \\
0\end{array}$ & T & 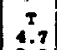 & & & 0 & $\begin{array}{c}4.2 \\
5.5\end{array}$ & $\begin{array}{l}1.2 \\
T\end{array}$ & 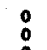 & $:$ & 38.1 \\
\hline 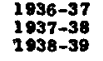 & $\begin{array}{l}0 \\
\vdots\end{array}$ & $\begin{array}{l}: \\
\vdots \\
0\end{array}$ & $\begin{array}{l}0 \\
: \\
0\end{array}$ & & $\left|\begin{array}{|c|c|}15.8 \\
15.8\end{array}\right|$ & & 11,8 & 8 & 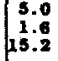 & $\left|\begin{array}{l}\mathbf{0} .8 \\
\mathbf{3} .3 \\
\mathbf{2 . 3} \\
.00\end{array}\right|$ & 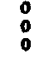 & $:$ & s6. \\
\hline $\begin{array}{l}10-40 \\
0 .-41 \\
0.41\end{array}$ & & & $\frac{0}{0}$ & & $\frac{T}{5.0}$ & & & & $\begin{array}{l}5.9 \\
8.7\end{array}$ & $0^{1.7}$ & 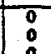 & $\begin{array}{ll}0 \\
0\end{array}$ & 0.0 \\
\hline $\begin{array}{l}1942-43 \\
1913-43-44\end{array}$ & 0 & : & $\begin{array}{l}0 \\
: \\
0\end{array}$ & : & $\mid \begin{array}{c}7 \\
4.6\end{array}$ & $\begin{array}{l}0.2 \\
0.2 \\
0.4\end{array}$ & 0. & 8.8 & 2.8 & 0.1 & $:$ & $:$ & $\begin{array}{l}48.0 \\
28.8\end{array}$ \\
\hline $\begin{array}{l}1944-45 \\
1845-46\end{array}$ & 0 & $:$ & $\begin{array}{l}0 \\
\vdots \\
0\end{array}$ & $:$ & & 2.9 & 0. & 14.3 & $\because 8$ & $\begin{array}{l}0.9 \\
0.8\end{array}$ & $:$ & $\begin{array}{l}: \\
: \\
0\end{array}$ & 86. \\
\hline 1047- 1047 & 0 & $:$ & $:$ & $:$ & $\left|\begin{array}{l}0.4 \\
1.7\end{array}\right|$ & $\begin{array}{l}22.8 \\
13.2\end{array}$ & 16. & 13. & 8 & $\ddot{\mathbf{T}}$ & $:$ & : & 80.3 \\
\hline 1949 & $:$ & $:$ & $:$ & $:$ & $\mid \begin{array}{c}3.9 \\
5 \\
0.8\end{array}$ & $\begin{array}{l}22.6 \\
7.4 \\
8.7\end{array}$ & & & $\begin{array}{l}5.6 \\
11.3 \\
4.3\end{array}$ & $\begin{array}{c}4.7 \\
0 \\
0\end{array}$ & $:$ & $\begin{array}{l}0 \\
: \\
0\end{array}$ & $\begin{array}{l}49.3 \\
37.1 \\
68.1\end{array}$ \\
\hline & & & & 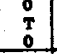 & $\begin{array}{l}0.6 \\
0.3 \\
13\end{array}$ & $\begin{array}{l}2.2 .2 \\
0.1\end{array}$ & & & $\frac{i}{i}$ & $\begin{array}{l}T \\
\\
\end{array}$ & & 0 & 22 \\
\hline & & & & & & 2.4 & & & & & & & \\
\hline
\end{tabular}

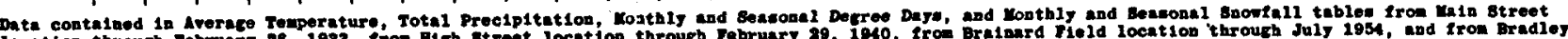

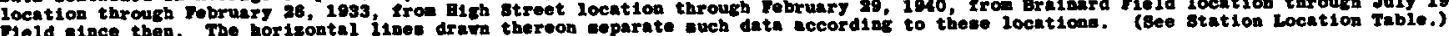

STATION LOCATION

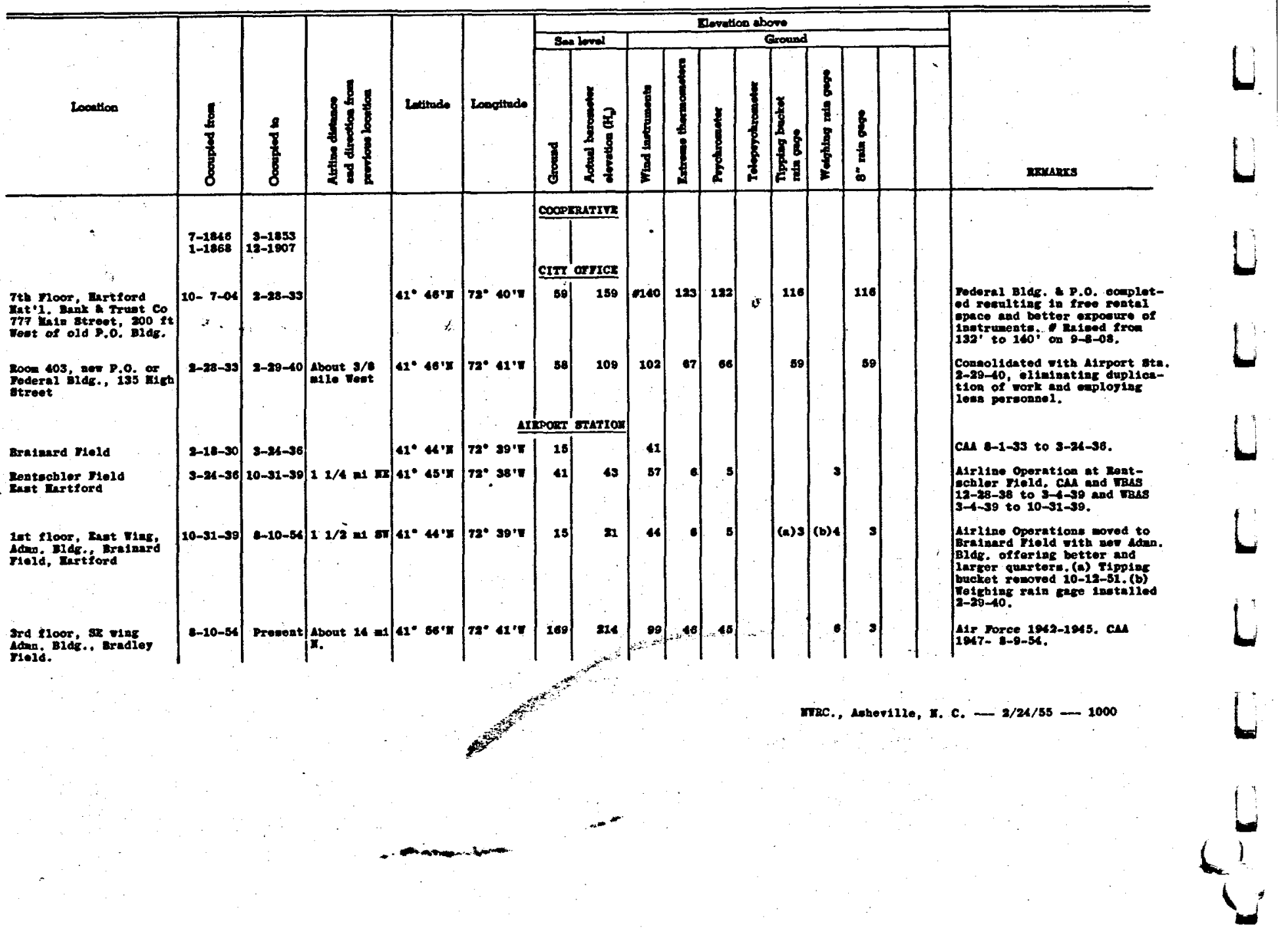




\title{
UVCLASSIFIED
}

\author{
APPENDIX E \\ GEOLOGY AND HYDROLOGY OF THE GOVERNMENT RESERVATION \\ NEAR MODDLETOWN, CONNECTICUT: \\ A PRELIMINARY REPORT \\ TO THE \\ UNITED STATES \\ ATOMIC ENERGY COMMISSION
}

by

E. S. Simpson

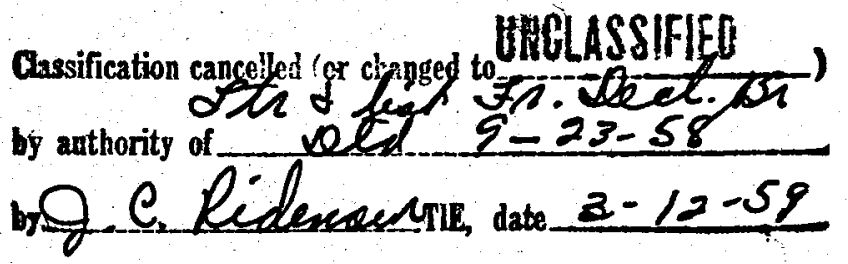

UNITED STATES DEPARTMENT OF THE INTERIOR GEOLOGICAL SURVEY

Albany, New York

September, 1955 


\section{A. ABSTRACT}

1. The proposed structures at the Middletown reservation will be built on a deposit of glacial sand that forms a terrace about 140 feet high overlooking the Connecticut River. Glacial sand probably also underlies the river. Beneath the sand is a layer of dense glacial till; beneath the till is folded and re-crystallized bedrock of Precambrian age.

The terrace material is permeable and its upper surface is relatively flat. It is tentatively concluded that ground water in the terrace discharges into the Connecticut River only. Therefore, a liquid spill would tend to percolate downward and thence move with ground water into the river. Conversely, any large-capacity well would withdraw ground water from most parts of the terrace and from the river.

Connecticut River is tidal at the reservation with a maximum tidal range of about $21 / 2$ feet, which decreases with increasing river discharge. Average discharge is about 17,300 cubic feet per second (cfs). During periods of low discharge, usually in August and September of each year, the effect of tide is sufficient to cause reversal of current. Maximum upstream current is estimated at about 1 foot per second. Maximum travel distance of upstream current is as yet unmeasured. Usual location of saline-fresh water contact is $\mathbf{1 3}$ to 20 miles downstream; during very low discharge saline water moves to within 10 miles of the reservation and in flood flows is completely flushed out of the river.

No public water-supply in the State of Connecticut takes Connecticut River water. The river is used for commercial and pleasure boating, swimming and fishing. No private consumptive use of river water is known, but inventory is yet to be made. It is belleved that no existing water well would be affected by plant operations, except, perhaps, the well of Hartford Electric Light Company at Benvenue.

From past records, it would appear that there is little danger from earthquakes, but inasmuch as they have occurred in relatively recent past, it would be well to make sure that all structures that are to contain "hot" liquids or which otherwise represent a hazard, be constructed to withstand moderate shocks. 


\section{B. INTRODUCTION}

1. This report gives the results of a preliminary investigation of the geology and hydrology of the government reservation at Middletown, Connecticut. Many data needed for a detailed analysis have not yet been obtained. Although the conclusions offered are believed to be essentially correct, they are subject to revision as more data become available. 


\section{TOPOGRAPHY AND DRAINAGE}

1. The government reservation is on the right (west) bank of the Connecticut River at Middletown, Connecticut, in the Middle Haddam topographic quadrangle. The reservation occupies roughly one square mile of land area, and is bounded both on north and east by the Connecticut River which makes a right-angle bend at this place. (See Fig 12).

Topographically (and geologically) the reservation may be divided into two halves. The western half which is hilly and underlain by bedrock and glacial till, reached a maximum elevation of about 350 feet. The eastern half, on which the proposed structures will be built, is a relatively flat-topped deposit of silt and sand and minor fine gravel, most of whose surface is at an elevation of 120 to 140 feet. For convenience, this deposit will be referred to as the terrace. It is bounded on north and east by the Connecticut River, and its surface contact with the underlying bedrock is marked very nearly by the existing north-south road that traverses the reservation.

The terrace has a steep outer slope facing the river. It is dissected by two large gullies, one near the north end and one near the south end, and also by two smaller gullies located near its center. Extending along the base of the terrace is a widened part of the flood-plain of the Connecticut River and-is underlain by river alluvium. It is about 3 miles long, including portions beyond the reservation. Its upstream half is a (usually) dry meadow having an average width of about 500 feet, while the downstream half is in large part a tidal flat whose maximum width is about 1500 feet. The two parts are separated by a bit of terrace that abuts the river's edge.

The Connecticut River is the master stream of the area, and all drainage from the reservation flows into it. The river in this reach is tidal and for the purposes of this report may be considered to be at sea-level elevation. On the reservation there is only one perennial stream and even it has been known to show no discharge in its upper reaches after a prolonged dry spell. Although it is unnamed on the topographic map, it will herin be called Maromas Brook. It rises in the hills, flows easterly toward the terrace, makes a loop convex southward following what appears to be the contact between the terrace and bedrock, then rapidly descends along the north gully to near river level, crosses the flood-plain where it forms sluggish pools, and thence flows into the Connecticut River. Maromas Brook has a small tributary that joins it on terrace level and which drains a pond occupying an abandoned rock quarry (hereinafter called Quarry Pond). The total drainage area of brook and tributary is about 1 square mile. There is no open body of water restricted to the terrace, probably because of the permeable nature of this deposit. 


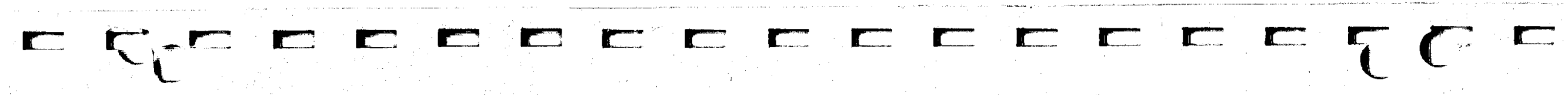

\section{TOPOGRAPHICAL MAP OF CANEL SITE AREA}

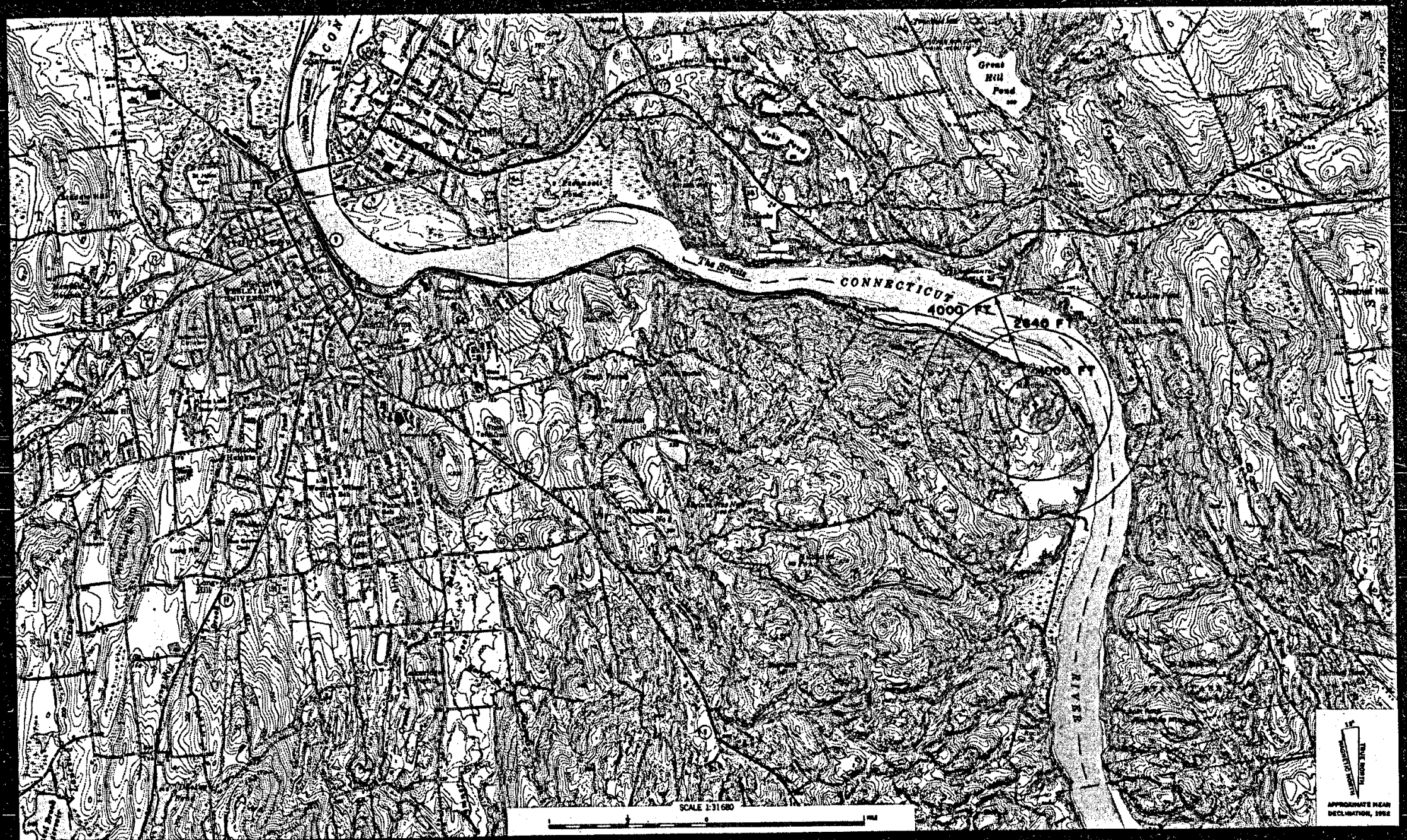




\section{GEOLOGY}

1. The geologic description that follows is based on a study of the literature given in the references and a study of the available driller's logs. The writer also spent a halfday in field inspection of the reservation. It is intended that further field study of the formations will be made and that a detailed geologic map of the area will be prepared; existing published maps are small-scale and generalized.

a. Bedrock

The bedrock underlying all of the reservation consists of a series of metamorphosed (recrystallized) sedimentary rocks of Precambrian age. They crop out in the hilly area of the western half and slope down steeply, but irregularly, under the terrace material. The stratigraphy of the rocks is complex and no attempt will be made to describe the several formations. It is believed sufficient for this report to note that although the lithologic make-up changes from formation to formation, the water-bearing characteristics of all are roughly similar. The rock material as such is nearly impermeable, but ground water is stored and transmitted through interconnecting systems of open joints and cracks. Such water-bearing openings are known to exist down to approximately 500 feet below land surface. Beyond that depth the weight of the over-lying material is believed to be great enough to prevent cracks from opening even though they may exist. In fact, the usual practical limit to the depth of water wells in this kind of rock is about 300 feet.

b. Unconsolidated Deposits (Overburden)

The overburden at the reservation is of three types: (1) glacial till which is a mixture of rock particles of all sizes from clay to boulders, and which was deposited directly by glacial ice, (2) glaciofluvial material derived from the ice and from exposed upland areas, but which was transported by running water, (3) river alluvium deposited by the Connecticut River in recent times.

1. Till

The till at the reservation is deposited directly on the underlying bedrock and the contact between the two ordinarily is fresh and sharp. The clay content of the till has not yet been determined, but driller's logs show it to be dense and probably only slightly permeable to the flow of ground water. It crops out in the western half of the reservation where it is found mantling almost all the bedrock. Its thickness possibly is on the order of 10 or 20 feet. However, thickness varies greatly from place to place, and cannot be predicted in advance of drilling or geophysical exploration. Where glaciofluvial material crops out at the surface, till is presumed to exist beneath it unless drilling or other data show the till to be missing.

2. Glaciofluvial Deposits

The bulk of the material on which the proposed structures will be built consists of stream-carried fine-to-coarse sand with minor quantities of silt and of fine gravel, all of which were deposited in a small temporary lake (or lakes) existing during the last stages of glacial decay. The upper surface of the deposit is relatively flat and is at an elevation of 120 to 140 feet-above sea-level. Its lower limit is not known but probably extends for some tens 
of feet below river grade. Thus, maximum thickness probably is on the order of 200 feet. Part of the bluff on the opposite side of the river appears to consist of the same material and may be connected to that on the government reservation via under-river deposits. The material appears to be thickest near the river's edge and thins rapidly toward its western boundary, where it is replaced by till and bedrock as the surface deposit. Between the rock and the glaciofluvial material there probably exists a fairly continuous layer of dense till. Most of the holes so far drilled into the terrace are too shallow to penetrate the till; in the few instances where till was penetrated it was found to be 8 or 10 feet thick. However, there appears to be a possibility that till underlying the glaciofluvial material near the north end of the terrace may be much thicker than 10 feet.

3. River Alluvium

The Connecticut River in recent times has cut a narrow flood-plain into the base of the terrace and deposited thereon a relatively thin layer of fine-grained alluvium. The deposit has little importance except insofar as it may affect the movement of water between the river and the underlying glaciofluvial material. Test wells for a possible water supply, drilled into the flood-plain several years ago by the City of Middletown, show the underlying material capable of yielding several hundred gallons of water per minute to individual wells. 


\section{E. HYDROLOGY}

1. In the remarks that follow, it is important to remember that the separation of hydrology into surface water and ground water is mainly for convenience of description and that the one is intimately related to the other.

\section{a. Surface Water}

The Connecticut River dominates the hydrology of the reservation. From the river will come virtually all the water required by the plant and into the river will go all the liquid waste discharged. At low water, the river is affected by tides from its mouth to Windsor Locks, a distance of 54 miles; in this reach, therefore, it is a drowned river or estuary. The government reservation is located about 24 miles up from the mouth of the river, or about $\mathbf{3 0}$ miles downstream from the tidal limit.

A report entitled, "The Salinity of the Connecticut River", was issued as Bulletin No. S-1 by the W.P.A. for Connecticut, October, 1938. The report shows (a) that East Haddam (which is about 10 miles downstream from the reservation) is about as far upstream as saline water is likely to extend, (b) that during flood flows, saline water is altogether flushed out of the river, and (c) the usual-location of the saline-fresh water contact is somewhere in the reach between Hadlyme and Essex (or approximately 13 to 20 miles downstream from the reservation). The location of the saline-fresh water contact is important because of the precipitating effect of saline water on suspended sediment. The sediment, 'in turn, probably would contain absorbed activity if such activity were to be discharged into the river.

The Connecticut River is gaged at Thompsonville, some 35 miles upstream from the reservation, and also near Middletown, some 3 miles upstream from the reservation. The Middletown gage provides discharge figures during periods of moderate to high stage only; in low stage the effect of tide makes discharge computation difficult. However, the Middletown gage provides a continuous record of river stage including tidal fluctuation which would be required in any special river study. A close approximation of discharge for all river stages at Middletown (which is practically the same as that at the reservation), may be computed from the record at Thompsonville by adding discharge from intervening tributaries. In this way, over 96 per cent of the discharge at Middletown is accounted for. Table 9 shows the computation of average discharge at Middletown; daily discharge nay be similarly computed from available records. (23) (23)

Table7. Approximate Average Discharge of the Connecticut River at Middletown (drainage area 10,870 square miles)

\begin{tabular}{|c|c|c|c|c|}
\hline \multirow[b]{2}{*}{ Stream } & \multirow{2}{*}{$\begin{array}{c}\text { Drainage } \\
\text { Area } \\
\text { (sq mi) }\end{array}$} & \multicolumn{3}{|c|}{ Discharge (cfs) } \\
\hline & & Max. & Min & Aver \\
\hline $\begin{array}{l}\text { River at Thompsonville } \\
\text { er at Broad Brook } \\
\text { River at Rainbow } \\
\text { at Hartford } \\
\text { River near East Hartford }\end{array}$ & $\begin{array}{r}9,661 \\
98.4 \\
584 \\
74.0 \\
74.5\end{array}$ & $\begin{array}{c}282,000(a) \\
7,360 \\
29,900 \\
5,650 \\
5,160\end{array}$ & $\begin{array}{r}1,060 \\
16(b) \\
5(b) \\
4(b) \\
1(b)\end{array}$ & $\begin{array}{r}15,910 \\
134 \\
1,000 \\
112 \\
111\end{array}$ \\
\hline Total & 10,490 & ---- & $\ldots$ & 17,300 \\
\hline
\end{tabular}

Connecticut River at Thompsonville

Scantic River at Broad Brook

Farmington River at Rainbow

Park River at Hartford

Hockanum River near East Hartford

10,490

1936; elevation of flood crest at Middletown 28. 2 feet above mean Flood of $\mathrm{M}$.

(b) Discharge regulated by river control.

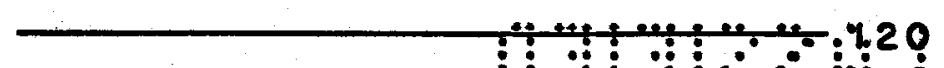


Thus it is seen that average discharge at Middletown is about $17,300 \mathrm{cfs}$. Since only $96 \%$ of the drainage area is represented, actual average discharge probably is a little higher.

As stated, the Connecticut River is tidal at the reservation. The maximum range is about $21 / 2$ feet, decreasing with increasing river discharge. During periods of low discharge, usually in August and September of each year, the effect of tide is sufficient to cause reversal of river current. The maximum upstream velocity is believed to be about 1 foot per second. It is intended that measurements be made to determine (a) maximum distance from the reservation of upstream travel of tidal currents, (b) velocity distribution of currents at river cross-sections both above and below the reservation, and (c) the effect, if any, of tidal currents on movement of river bed material.

The remaining bodies of surface water on the reservation are Marontas Brook and Quarry Pond as previously described. Aside from noting that their total drainage area is about 1 square mile, little is known at present of their hydrologic characteristics. It is intended that the capacity of Quarry Pond both to store and to yield water be measured, and that the main discharge characteristics of Maromas Brook be measured. There is reason to believe that Maromas Brook, as it flows over the upper part of the terrace, loses water to the relatively permeable terrace material.

b. Ground Water

In bedrock, recoverable ground water occurs in interconnected open joints and cracks in the rock to a maximum depth of about 500 feet below land surface. In the overburden, recoverable ground water occurs in the interconnected pore spaces between the individual grains that make up the deposit, except that in till and perhaps in alluvium the pore spaces are so small as to make these deposits relatively impermeable.

The western hilly area underlain by rock and till is poorly drained, and (outside the reservation) numerous small swamps dot the countryside. Thus, the water table in this area appears to be close to the surface. It is also probable that Quarry Pond is fed by ground water from the surrounding bedrock and, therefore, the elevation of the pond surface also is the elevation of the water table at that place.

In the unconsolidated material of the terrace the water table lies much deeper. It appears to descend, almost with till, to nearly river stage. In a foundation boring drilled through the terrace the water table was encountered about 92 feet below the surface, till was encountered about 130 feet below the surface, and bedrock (gneiss) was encountered 138 feet below the surface.

It is not known whether or not the elevation of the water table in the terrace material is identical with that in the bedrock. It appears reasonable to suppose that the till acts as a confining layer and makes possible the existence of artesian water in the underlying bedrock. In this view, the elevation of the water table in the rock (or piezometric surface) would be the higher, and there would be a tendency for water in the rock to move up through the till and into the glaciofluvial material. The necessary head would be derived from the outcrop area in the hills immediately west of the terrace. 
Although very few data are available relative to ground water movement, it appears possible to tentatively offer the following conclusions:

1. The terrace material is isolated from surrounding aquifers. That is, ground water in the terrace under natural gradient discharges into the Connecticut River only. Ground water in the underlying rock might move to deeper rock horizons but, if so, the rate of movement is slow. Ground water in the terrace is prevented from entering underlying rock by the till layer, where such layer exists, and possibly by higher head of ground water in rock. The Connecticut River probably prevents ground water movement between the terrace at the government reservation and the terrace on the opposite side of the river.

2. If ground water is pumped out of the terrace from wells penetrating below river stage, there is every reason to suppose that if the quantity pumped is large enough (say on the order of $100 \mathrm{gpm}$ ), the natural gradient to the river would be reversed and river water would enter terrace material.

3. Pumping from anywhere in the terrace, including most, if not all, of the flood-plain along the terrace base, would tend to draw water both from the Connecticut River and also perhaps from all other parts of the terrace.

It is intended to drill observation wells and to conduct aquifer-performance (pumping) tests to obtain data on the shape of the water table and on aquifer characteristics. These data will make possible a more precise and accurate analysis of ground water movement. 


\section{F. WATER UTILIZATION}

1. The Connecticut River is navigable to barge and river boat traffic as far north as Hartford, or about 45 miles upstream from its mouth. The depth of channel is maintained by Corps of Engineers at about 15 feet. Pleasure craft of all sizes use the river in increasing numbers. However, there is no public water supply in the State of Connecticut which takes Connecticut River water. At places, the water is used for industrial purposes, mainly for cooling. In summer, an unknown number of persons use the river for bathing and swimming. Fishing takes place on a small scale, much of it for individual sport. Commercial fishing on the Connecticut River is restricted mostly to the taking of shad during the period from about April 1, to June 15, although yellow perch and eel are caught commercially at other times of the year. The average yearly shad catch by commercial fishermen is estimated by the State Board of Fisheries and Game to be about 100,000 , and to be valued at about $\$ 100,000$.

Surrounding farms and homes obtain water supplies from individual wells, but with the possible exception of the supply well of the Hartford Electric Light Company steam plant near Benvenue, there appears to be no existing well supply that might be affected by future operations at the reservation. Wells on farms to be taken by the government are excluded from consideration. The City of Middletown drilled test wells in the flood-plain inside the north end of the (now) government reservation several years ago. The city has expressed interest in developing a well-field there, but so far no decision on the matter has been reached.

There are three open reservoirs in the hills a mile or so west of the reservation that supply a large State hospital. Since all are at elevations as high or higher than the highest part of the reservation, there is no possibility for water-borne contamination to reach them.

It is intended to make an inventory of private water supplies in the vicinity of the reservation and along the Connecticut River. It is also intended to sample selected supplies for radioanalyses in advance of plant operation. 


\section{G. EARTHQUAKE HISTORY OF CONNECTICUT}

1. The State of Connecticut is reported to have had twelve earthquakes which had their epicenters within the State boundaries. Undoubtedly more shocks have occurred, but they were not recorded because of their small areal influence and low intensity. The recorded shocks had intensities that varied from 4 to 8 on the Rossi-Forel scale of intensities. The Rossi-Forel scale of intensities classified earthquakes into ten groups according to their intensity at the epicenter. The recorded Connecticut shocks which varied from 4 to 8 in intensity would be described as follows:

Intensities

4 (feeble shock)

5 (shock of moderate intensity)

6 (fairly strong shock)

7 (strong shock)

8 (very strong shock)
Description

Felt by persons in motion; disturbance of movable objects, doors, windows; cracking of ceilings.

Felt generally by everyone; disturbance of furniture, beds, etc.; ringing of some bells.

General awakening of those asleep; general ringing of bells; oscillation of chandeliers; stopping of clocks; visible agitation of trees and shrubs; some startled people leaving their dwellings.

Overthrow of movable objects; fall of plaster; ringing of church bells; general panic, without damage to buildings.

Fall of chimneys; cracks in walls of buildings.

The following table gives the date, location, square miles of area affected, and the intensity of the reported shocks:

24

Table(2) Earthquakes of Record in the State of Connecticut

Date

May 16, 1791

August 28, 1791

January 11, 1792

March 6, 1794

August 11, 1805

August 23, 1827

April 12, 1837

August 9, 1840

June 30,1858

July 28, 1875

February 5, 1908

November 14, 1925
Locality

East Haddam

"

if

11

เะ

New London

Hartford

Southern Conn.

New Haven

Connecticut

Housatonic Valley

Hartford
Lat. Long. Area $N \quad W$ sq mi

Intensity $\begin{gathered}\text { Distance from } \\ \text { Middletown, mi }\end{gathered}$

$41.5 \quad 72.5 \quad 35,000 \quad 8$

$-$

$-$

$-$

$-$

-

41.4

41.7

41.5

41.3

41.8

72.7

72.7

72.9

73.0

73.2

$-$

$-$

$41.5 \quad 72.5$
-

15 S. E.

-

-

$-$

32 S. E.

$19 \mathrm{~N}$.

$7,500 \quad 6$

$1,000 \quad 4-5$

2,000

6

25 S. W.

-

N 
From the past records it would appear that there is little danger from earthquakes, but, inasmuch as they have occurred in the relatively recent past, it would be well to make sure that all structures that are to contain "hot". liquids or otherwise represent a hazard be constructed to withstand moderate shocks. 


\section{REFERENCES}

Flint, R. F., 1930, The Glacial Geology of Connecticut: Connecticut Geological and Natural History Survey, Bulletin No. 47.

Heck, N. H., Earthquake History of the United States, Part I: United States Department of Commerce, Coast and Geodetic Survey Publication Serial No. 609.

United States Geological Survey, 1950, Surface Water Supply of the United States North Atlantic Slope Basins: United States Geological Survey Water-Supply Paper 1171.

Waring, G. A., 1920, Ground Water in the Meridan Area, Connecticut: United States Geological Survey Water-Supply Paper 449.

W. P. A., 1938, The Salinity of the Connecticut River: W. P. A. for Connecticut, Bulletin No. S-1. 
This document contains rest data as defined in the Atomic Energy Act of 1946. Whansmittal or the disclosure of its contents in any muth to an unauthorized person is prohibited.

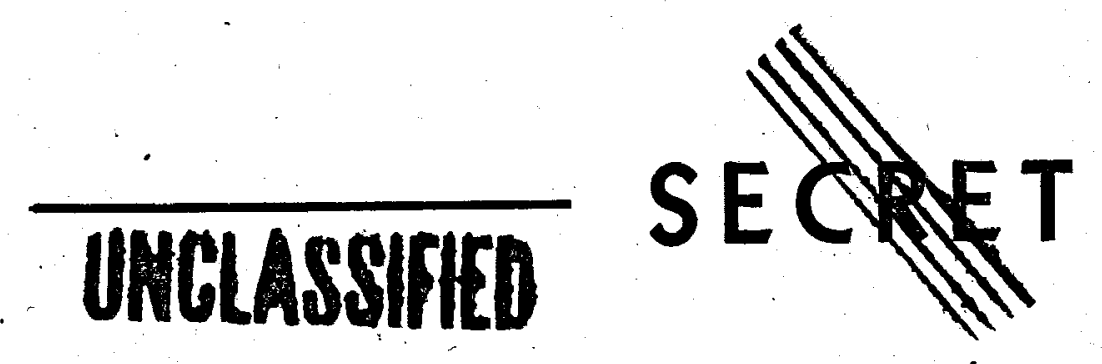

